\title{
Oceanographic processes and morphosedimentary products along the Iberian margins: A new multidisciplinary approach
}

\author{
F. Javier Hernández-Molina ${ }^{\mathrm{a}, *}$, Anna Wåhlin ${ }^{\mathrm{b}}$, Miguel Bruno ${ }^{\mathrm{c}}$, Gemma Ercilla $^{\mathrm{d}}$, Estefanía Llave ${ }^{\mathrm{e}}$, Nuno Serra ${ }^{\mathrm{f}}$, \\ Gabriel Rosón ${ }^{\mathrm{g}}$, Pere Puig ${ }^{\mathrm{d}}$, Michele Rebesco ${ }^{\mathrm{h}}$, David Van Rooij ${ }^{\mathrm{i}}$, David Roque ${ }^{\mathrm{j}}$, César González-Pola ${ }^{\mathrm{k}}$, \\ Francisco Sánchez ${ }^{1}$, María Gómez ${ }^{\mathrm{m}}$, Benedict Preu ${ }^{\mathrm{n}}$, Tilmann Schwenk ${ }^{\mathrm{o}}$, Till J.J. Hanebuth ${ }^{\mathrm{p}, \mathrm{q}}$, \\ Ricardo F. Sánchez Leal ${ }^{\mathrm{r}}$, Jesús García-Lafuente ${ }^{\mathrm{s}}$, Rachel E. Brackenridge ${ }^{\mathrm{t}, \mathrm{u}}$, Carmen Juan ${ }^{\mathrm{d}, \mathrm{i}}$, \\ Dorrik A.V. Stow ${ }^{\mathrm{t}}$, José María Sánchez-González ${ }^{\mathrm{g}}$
}

a Dept. Earth Sciences, Royal Holloway Univ. London, Egham, Surrey TW20 OEX, UK

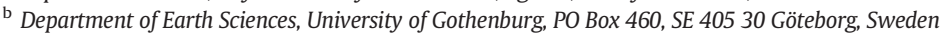

c CACYTMAR. Univ. Cádiz, Avda República Saharaui S/N, Puerto Real, 11510, Cádiz, Spain

d CSIC, ICM, Paseo Marítimo de la Barceloneta, 37-49, 08003 Barcelona, Spain

e Instituto Geológico y Minero de España Ríos Rosas, 23, 28003, Madrid, Spain

${ }^{f}$ Institut für Meereskunde, Univ. Hamburg, Bundesstr. 53, 20146, Hamburg, Germany

${ }^{g}$ Facultad de Ciencias do Mar, Univ. Vigo, 36200 Vigo, Spain

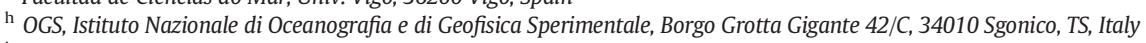

${ }^{i}$ Renard Centre of Marine Geology, Dept. of Geology and Soil Science. Ghent University, Krijgslaan, 281 S8 B-9000 Gent, Belgium

j CSIC, ICMAN, Campus Universitario Rio San Pedro s/n. Puerto Real, Cádiz, CP 11510, Spain

k Instituto Español de Oceanografia, C.O. Gijón. c/ Príncipe de Asturias 70 Bis., CP 33212, Gijón, Spain

${ }^{1}$ Instituto Español de Oceanografía, C.O. de Santander, Promontorio San Martín s/n, Apdo 240, 39080 Santander, Spain

m Instituto Español de Oceanografia, c/Corazón de María 8, 28002, Madrid, Spain

${ }^{n}$ Chevron Upstream Europe, Chevron North Sea Limited, Seafield House, Aberdeen AB15 6XL, UK

${ }^{\circ}$ MARUM - Center for Marine Environmental Sciences and Faculty of Geosciences, University of Bremen, Bremen, Germany

${ }^{\mathrm{p}}$ School of Coastal and Marine Systems Sciences, Coastal Carolina University, P.O. Box 261954, Conway, SC 29528, USA

${ }^{9}$ Marine Sedimentation Systems Group, MARUM - Center for Marine Environmental Sciences, University of Bremen, Leobener Strasse, 28359, Bremen, Germany

${ }^{r}$ Instituto Español de Oceanografía, C.O. de Cádiz, Muelle de Levante s/n, P.O. Box 2609, 11006 Cádiz, Spain

${ }^{s}$ Physical Oceanography Group, University of Malaga, ETSI Telecomunicación, Campus de Teatinos, s/n 29071 Málaga, Spain

${ }^{t}$ Institute of Petroleum Engineering, Heriot-Watt Univ., Edinburgh EH14 4AS, Scotland, UK

u Shell International Exploration \& Production, B.V. Carel van Bylandtlaan 05.0B.03, 2596, HR, The Hague, Netherlands

\section{A R T I C L E I N F O}

\section{Article history:}

Received 6 June 2015

Received in revised form 13 November 2015

Accepted 17 December 2015

Available online 20 December 2015

\section{Keywords:}

Iberian margins

Oceanographic processes

Bottom currents

Sedimentary processes

Contourites

\begin{abstract}
A B S T R A C T
Our understanding of bottom-currents and associated oceanographic processes (e.g., overflows, barotropic tidal currents) including intermittent processes (e.g., vertical eddies, deep sea storms, horizontal vortices, internal waves and tsunamis) is rapidly evolving. Many deep-water processes remain poorly understood due to limited direct observations, but can generate significant depositional and erosional features on both short and long term time scales. This paper represents a review work, which describes for the first time these oceanographic processes and examines their potential role in the sedimentary features along the Iberian continental margins. This review explores the implications of the studied processes, given their secondary role relative to other factors such as mass-transport and turbiditic processes, and highlights three major results: a) contourite depositional and erosional features are ubiquitous along the margins, indicating that bottom currents and associated oceanographic processes control the physiography and sedimentation; b) the position of interfaces between major water masses and their vertical and spatial variation in time specifically appears to exert primary control in determining major morphologic changes along the slope gradient, including the contourite terraces development; and c) contourites deposits exhibit greater variation than the established facies model suggests. Therefore, a consistent facies model however faces substantial challenges in terms of the wide range of oceanographic processes that can influence in their development. An integrated interpretation of these oceanographic processes requires an understanding of contourites, seafloor features, their spatial and temporal evolution, and the near-bottom flows that form them. This approach will synthesize oceanographic data, seafloor morphology, sediments and seismic images to improve our knowledge of permanent and intermittent processes around Iberia, and evaluate
\end{abstract}

\footnotetext{
* Corresponding author.

E-mail address: Javier.Hernandez-Molina@rhul.ac.uk (F.J. Hernández-Molina).
} 
their conceptual and regional role in the margin's sedimentary evolution. Given their complexes, threedimensional and temporally-variable nature, integration of these processes into sedimentary, oceanographic and climatological frameworks will require a multidisciplinary approach that includes Geology, Physical oceanography, Paleoceanography and Benthic Biology.

\section{Introduction}

Deep-marine settings have been considered until 1980s as relatively low energy and quiescent depositional environments where deepwater masses flow as relatively slow-moving tabular bodies and deposition is episodically interrupted by down-slope gravity driven processes. However, since the 1990s it has been demonstrated that deep-water masses can exhibit relatively high velocity and play a dominant depositional role in certain areas (e.g., Rebesco et al., 2014). These conditions hold especially when water masses interact with local seafloor irregularities (i.e., seamounts, ridges, hills, mounds, banks, scarps). Flow through deep oceanic gateways, straits or basins can also generate high velocity and turbulent flows, resulting in regional-scale erosional, depositional and mixed morphological features. Understanding these seafloor features therefore requires a more detailed model of bottom current effects.

The general term 'bottom current' refers to deep-water currents capable of eroding, transporting, and depositing sediments along the seafloor (Rebesco and Camerlenghi, 2008). Background bottom currents are the result of both the ocean thermohaline circulation (THC) and the ocean wind-driven circulation (Rahmstorf, 2006). They generally exhibit persistent net flow along-slope (following the local bathymetry), but can considerably vary in direction and velocity (Stow et al., 2009). Overflows, tides, including internal tides and other intermittent processes such as bottom reaching (vertical) eddies, deep sea storms, (horizontal) vortices, internal waves, solitons, tsunami related currents, rogue waves and cyclonic waves (during storms and hurricanes) can also affect bottom currents (Fig. 1) (e.g., Shanmugam, 2012a, 2013a, 2013b, 2014; Rebesco et al., 2014). These processes modulate the bottom currents and their speed, instantaneous direction, and tend to develop local and regional hydrodynamic structures (e.g., cores, branches, filaments, eddies, vortices, local turbulence, internal waves, helicoidal flows, vertical columns). Many of these oceanographic deep-water processes are poorly understood but can generate pervasive depositional and erosional features over both short- and long-term time scales (Shanmugam, 2013b; Rebesco et al., 2014 and reference therein).

Contourites are defined as sediments deposited or substantially reworked by the persistent action of bottom currents (e.g., Stow et al., 2002a; Rebesco, 2005; Rebesco et al., 2014). The term "contourites" was originally intended to define sediments deposited in the deep sea by contour-parallel thermohaline currents (Hollister and Heezen, 1967). Usage of the term has subsequently widened to include a larger

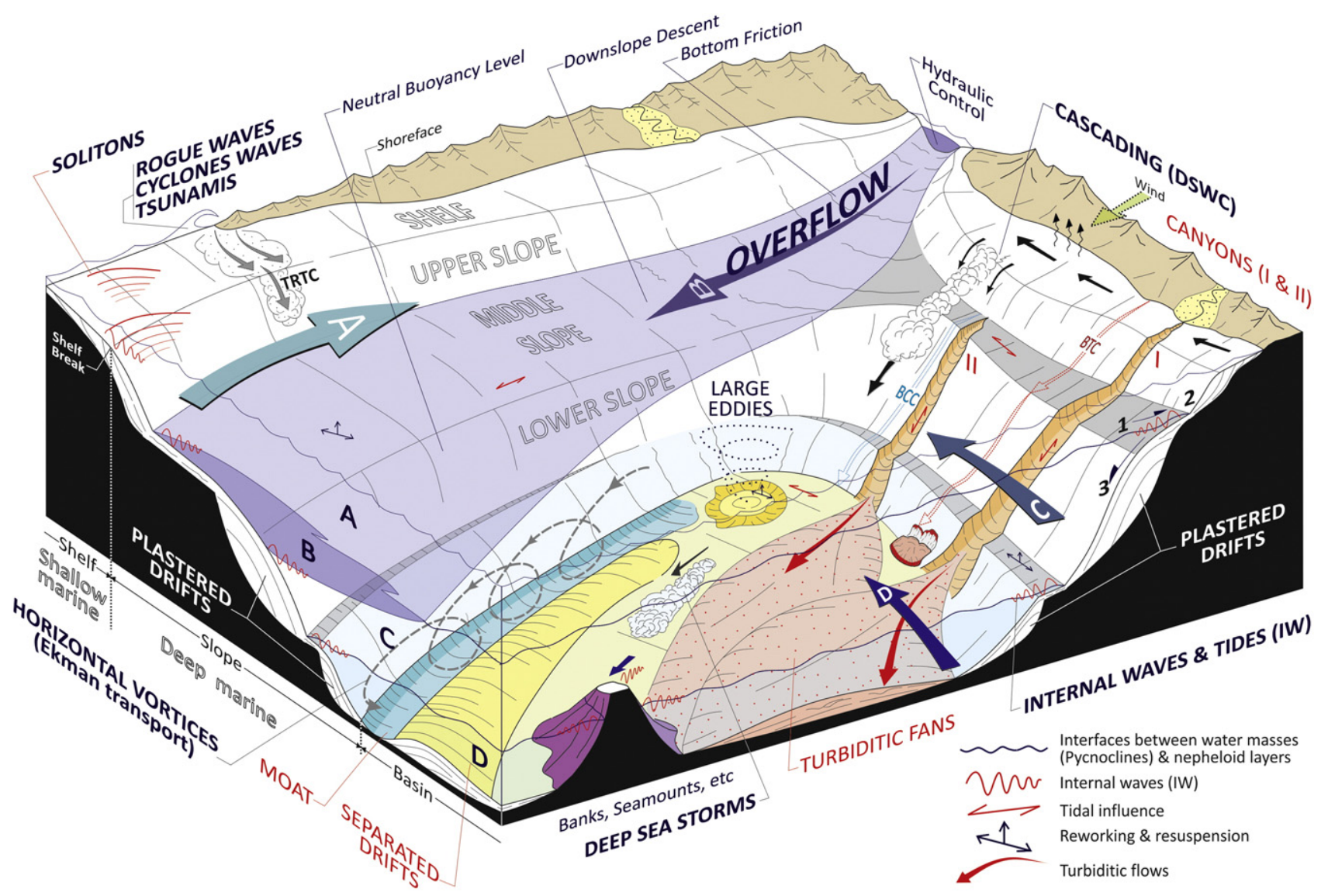

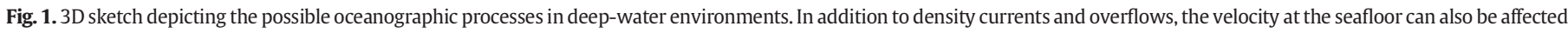

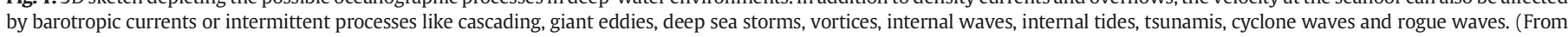
Rebesco et al., 2014, with permission from Elsevier). 
range of deposits affected by different types of currents (Rebesco et al., 2014). Bottom currents are capable of building thick and extensive accumulations of sediments referred to as "contourite drifts". The term "contourite depositional system" (CDS) refers to large contourite deposits (drifts) associated with erosional features in an environment dominated by along-slope processes due to a particular water mass (Hernández-Molina et al., 2003, 2008a, 2008b, 2009).

The Iberian continental margins have had a very complex and varied origin as well as geodynamic and sedimentary evolution. For decades, many studies have been carried out on the structure and evolution of these margins (e.g., Maestro et al., 2015 and reference therein). The circulation of water masses around Iberia leads to the development of bottom currents and rather unknown associated oceanographic processes, some of which impinge upon the seafloor with relatively high velocity and interact along the continental slope. The resulting contourite erosional and depositional features comprise extensive, complex and often poorly known CDSs in various geological settings, consituting valuable sedimentary records of margins evolution (see compilation from Hernandez-Molina et al., 2011; Llave et al., 2015a, 2015b). Therefore, the present work has three main objectives: (1) to combine previous work and new data on describing persistent or intermittent oceanographic processes associated with bottom currents circulation along the Iberia continental margins; (2) to evaluate their role in determining the shape, potential sedimentary products and evolution of the margins; and (3) to propose some future considerations contemplating the implications of these findings.

\section{Methodology and data set}

Present work constitutes mostly a review of described persistent or intermittent oceanographic processes associated with bottom current circulation along the Iberia continental margins. Such a compilation is difficult, since there is a high degree of heterogeneity in both data coverage and terminology. It represents a collaborative work achieved during the last years by Geologists, Physical Oceanographers, Paleoceanographers and Benthic Biologists. A varied data set were compiled from numerous bibliographic sources or unpublished, including: radar images; conductivity, temperature and depth (CTD) stations; Acoustic Doppler Current Profiler (ADCP); time series observations of the near-bottom current speed, potential temperature and suspended sediment concentration (SSC); submarine bottom photographs; superficial samples; swath bathymetry data; side scan sonar images; highand low-resolution seismic reflection profiles; and sediments samples taken by drilling and numerical modelling.

A first part of the work offers a conceptual description of persistent or intermittent oceanographic processes associated with bottom current circulation inspired in recent works from Shanmugam (2012a, 2013a, 2013b, 2014) and Rebesco et al. (2014), but including, by first time, an exhaustive compilation of them around the Iberian margins. The second part describes how to proceed with the unique research challenge of integrating these complex, three-dimensional and temporally variable oceanographic processes into sedimentary and climatological models.

\section{Oceanographic processes}

\subsection{Bottom currents and thermohaline circulation}

The large-scale deep-water circulation is a critical part of the global conveyor belt that regulates the Earth's climate (Rahmstorf, 2006; Kuhlbrodt et al., 2007). In regions where the deep ocean currents are close enough to the ocean bottom they may shape the deep seafloor. As a first order, dense water formation at high latitudes drives the global THC. Salinity or temperature driven density variations cause sinking of the surface water masses towards greater depths and control their subsequent transport and eventual global distribution. Deep-water formation is closely associated with convection in a few localities. These mainly occur in the subpolar convergence zone of the Northern Hemisphere and the convergence zone of the Antarctic polar front in the Southern Hemisphere. The principal deep-water masses forming part of the THC include the North Atlantic Deep Water (NADW) and the Antarctic Bottom Water (AABW), which spread across the deepest marine domains, as Deep Western Boundary Currents (DWBC) (Rahmstorf, 2006). Bottom circulation and distribution along the oceanic basins is conditioned by their proximity to high-latitude input sources, seafloor morphology, inter-oceanic connection via deep gateways and the Coriolis Effect (Kennett, 1982; Faugères et al., 1993; Rahmstorf, 2006). Other bottom currents, such as the extension of the wind-generated currents, are not linked to THC. These latter currents include the Gulf of Mexico current system (e.g., Loop Current; Wunsch, 2002) and the Antarctic Circumpolar Current (Orsi et al., 1995).

Bottom-water masses move generally relatively slowly as laminar flows over their global course $(<3 \mathrm{~cm} / \mathrm{s})$. Regional and local bottom current velocities exhibit local heterogeneity due to varying seafloor stress and other current instabilities, such as mesoscale variability. Western stretches of ocean basins and topographic obstacles along the seafloor facilitate higher velocities ( $>0.6-1 \mathrm{~m} / \mathrm{s}$ ) (Stow et al., 2009; Hernandez-Molina et al., 2011). Bottom water behaviour and velocity partially affect the seafloor through lateral transport of suspended particulate matter in the water column. This material is up to 10 times higher in concentration in the deep nepheloid layer (at 50-200 m above the seafloor) of the Deep Western Boundary Currents compared with other oceanic areas (Rebesco et al., 2014). A sufficiently active bottom current acting for a prolonged period of time will thus profoundly affect the seafloor by winnowing of fine-grained sediments, yelding large-scale erosion, depositional and mixed features (e.g., Stow et al., 2002b; Rebesco and Camerlenghi, 2008; Rebesco et al., 2014). Bottom currents represent long-term hydrologic conditions on geological time scales. The establishment of the main CDSs around the world in fact coincides with the Eocene/Oligocene boundary ( $32 \mathrm{Ma}$ ), and was more recently reactivated by THC during the Middle Miocene (HernándezMolina et al., 2008a).

The topic of bottom current processes around Iberia is addressed by Hernandez-Molina et al. (2011) and Llave et al., 2015a, 2015b (this special issue). Along the Iberian margins, several important bottom currents shape the continental margins and abyssal plains (e.g., Iorga and Lozier, 1999; Millot, 1999, 2009, 2014; Serra et al., 2010a). These currents derive primarily from the Western Mediterranean Deep Water (WMDW) and the Levantine Intermediate Water (LIW) in the Alboran Sea, as well as the Mediterranean Overflow Water (MOW) and the Lower Deep Water (LDW) in the Atlantic (see the water masses compliation in Hernandez-Molina et al., 2011 and Llave et al., 2015a, 2015b, this issue). Well-developed CDSs around Iberia (e.g., Portuguese margin) have not been systematically interpreted according to bottom currents models and thus are not well understood.

\subsection{Overflows}

Overflows constitute permanent oceanographic processes related to: 1 ) flow over a topographic barrier from a regional basin into the open ocean (Figs. 1 and 2). The Denmark Strait Overflow Water (DSOW); Iceland-Scotland Overflow Water (ISOW) and MOW (Price and Baringer, 1994; Legg et al., 2009) offer good examples of the first type of overflow. The second type of overflow occurs in association with deep gateways such as the Bruce Passage between the Weddell Sea and Scotia Sea (Legg et al., 2009; Lobo et al., 2011; García et al., 2016a, this special issue) or the overflow of AABW from the Brazil Basin into the North Atlantic Basin across the Atlantic ridge or in the Gulf of Mexico (Legg et al., 2009). In the aforementioned cases, a dense gravity current, carrying a particular water mass, descends the regional slope to a greater depth until it reaches density equilibrium. Entrainment of surrounding water, bottom friction and inertial 


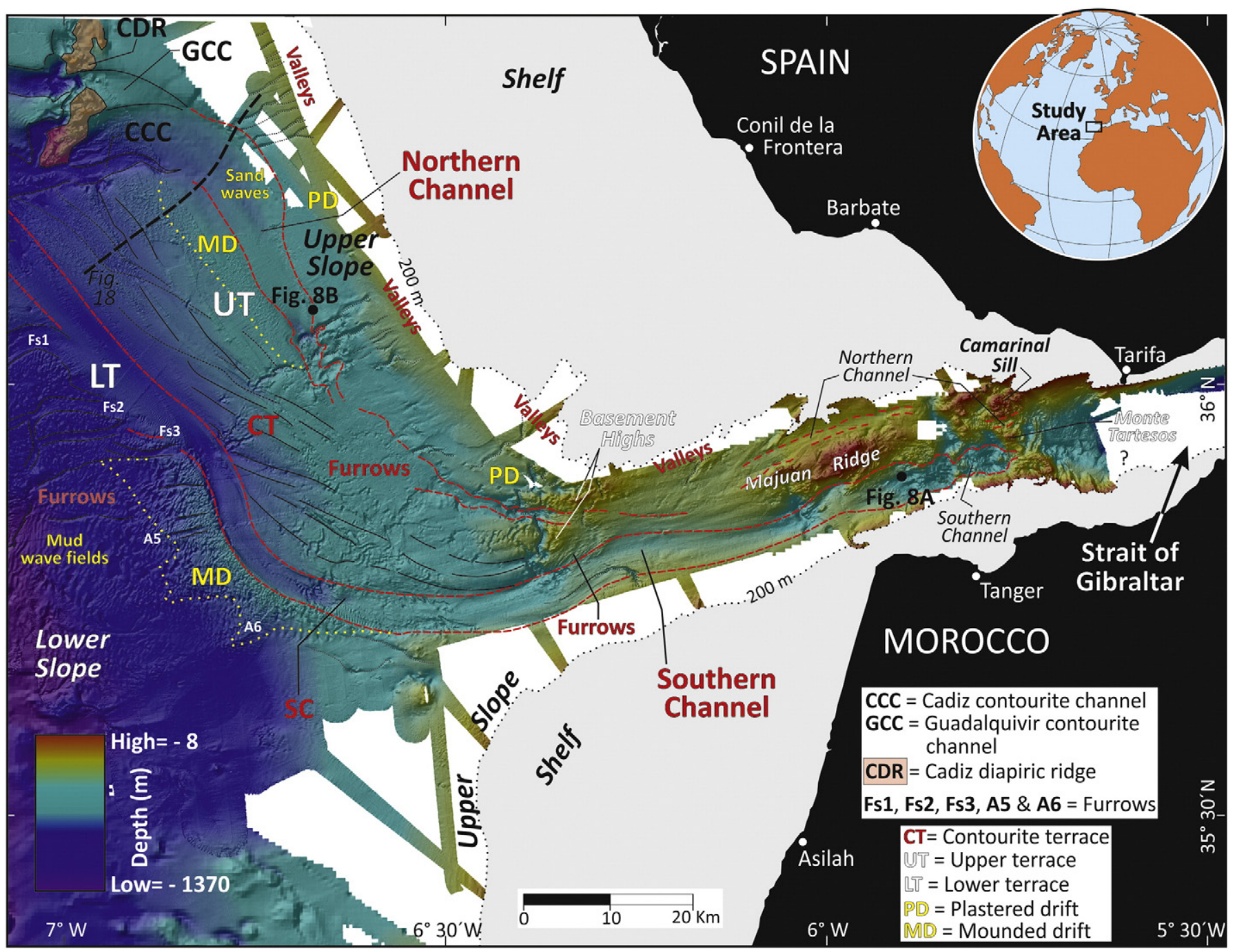

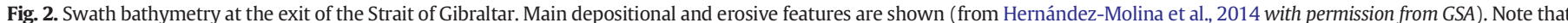
furrows are oblique to the main channels due to the secondary circulation related to the benthic Ekman transport.

accelerations modify the bottom current along the slope (Fig. S1, in Supplementary material). Bottom friction and the Earth rotation induce the Ekman bottom boundary layer (e.g., Pedlosky, 1996; Wåhlin and Walin, 2001), which produces a net transport to the left in the Northern Hemisphere (Fig. S1). Although the frictional transport is confined to a thin layer near the bottom (the Ekman boundary layer), it affects the whole water column asymptotically. The dense water adjusts to the divergence of the frictional transport, which acts as a horizontal diffusive process, minimizing the curvature of the dense interface. The lower (seaward) edge moves downhill as the Ekman layer expels the Ekman transport from its interior (e.g., Wåhlin and Walin, 2001). At the upper (landward) edge, the dense interface then becomes almost horizontal, with diminished geostrophic velocity and frictional transport (e.g., Wåhlin and Walin, 2001). The combined frictional effect over the entire outflow causes it to gradually widen, keeping the upper horizontal boundary at a nearly constant depth (e.g., Borenäs and Wåhlin, 2000). If these processes occur over a laterally varying bottom slope, they act to split the flow into two or more cores and branches, as suggested for example, in an interpretation of the Mediterranean Outflow (Borenas et al., 2002; Serra et al., 2010a, 2010b). As dense water passes from its formation site into the open ocean as an overflow, it undergoes mixing with the overlying water column. This process determines the eventual properties and volume transport of the resultant bottom currents, and triggers eddy formation (Legg et al., 2009).
The main overflow example in the Iberian margins stems from MOW dynamics during the late Miocene opening of the Gibraltar gateway (Duggen et al., 2003; Bache et al., 2012; Roveri et al., 2014). The Strait of Gibraltar, which consists of a $60 \mathrm{~km}$ long sill and narrow gateway (Armi and Farmer, 1988), plays a key role in water exchange between the Mediterranean Sea and the Atlantic Ocean. The excess evaporation over precipitation ( 0.5 to $0.8 \mathrm{~m} / \mathrm{yr}$ ) dramatically enhances salinity and density of the Mediterranean, relative to waters of the adjacent Atlantic Ocean (Millot et al., 2006). Mediterranean salinity tongues develop in the Atlantic Ocean from overflow $(0.68 \mathrm{~Sv})$ of dense, warm $\left(13^{\circ} \mathrm{C}\right.$ ) and highly saline (37) water (Bryden et al., 1994; Candela, 2001; Serra et al., 2010a). Mediterranean Levantine Intermediate Water (LIW) and Western Mediterranean Deep Water (WMDW) mix, when they flow out through the Strait and originate the MOW that is around 2 times saltier than any other Atlantic water mass. The overflow spills over the Strait of Gibraltar sills and cascades from $300 \mathrm{~m}$ depth at the edge of the strait down the continental slope of the eastern Gulf of Cádiz. As it does so, it entrains the overlying, less dense North Atlantic Central Water (NACW) (Johnson and Stevens, 2000). Overflows typically occur at velocities of 50 to $100 \mathrm{~cm} / \mathrm{s}$ (Legg et al., 2009), but in the case of MOW, the current velocity decreases from around $200 \mathrm{~cm} / \mathrm{s}$ in the neighbourhood of the Camarinal sill and its western approaches (Sánchez-Román et al., 2009; Gasser et al., 2011), down to 60$100 \mathrm{~cm} / \mathrm{s}$ further to the northwest. From the first $100 \mathrm{~km}$ of the overflow 
path, volume transport increases by a factor of three to four (Serra et al., 2010a; Rogerson et al., 2012). As it descends, the overflow veers north and follows the Iberian continental margins, approaching its neutral buoyancy as it nears $8^{\circ} \mathrm{W}$ at about $1000 \mathrm{~m}$ depth (Ochoa and Bray, 1991; Baringer and Price, 1997, 1999; Käse and Zenk, 1996; Ambar et al., 2002, 2008; Bower et al., 2002; Serra et al., 2005, 2010a; García-Lafuente et al., 2009).

In the Gulf of Cádiz, friction in the bottom Ekman boundary layer and entrainment in its upper part affect the MOW plume (Baringer and Price, 1997; Gasser et al., 2011). The vertical distribution of the alongstream velocity comprises two zones separated by a velocity maximum (called the plume nose). They consist of an upper (interfacial) layer characterised by sharp velocity and salinity gradients, and a bottom layer characterised by constant salinity and a sharp decrease in velocity (Johnson et al., 1994a, 1994b). Secondary across-stream circulation spreads water from the upper layer upslope and dense water from the bottom layer downslope. In the eastern Gulf of Cádiz, near the Strait of Gibraltar, this overflow is associated with sandy-sheeted drifts, scours, ripples, sand ribbons and sediment waves (Nelson et al., 1993), and generates large terraces and erosive channels (Fig. 2) (HernándezMolina et al., 2014). The secondary circulation here is especially relevant to the erosion, resuspension and deposition of sediment, as well as to the formation of large contourite features (Hernández-Molina et al., 2014).

Other examples of open-ocean overflow could happen between oceanic basins with different depths (Legg et al., 2009). A possible case to be explored along the Iberian margins could theoretically develop through the Theta Gap, a passage formed between La Coruña and Finisterre structural highs (Fig. 3), and narrows to approximately $5 \mathrm{~km}$ wide between the Biscay abyssal plain (average water depth of $5100 \mathrm{~m}$ ) and the Iberian abyssal plain (about $5300 \mathrm{~m}$ deep), or other deep channels between the abyssal plains. Heezen et al. (1959) first described the Theta Gap connection as "a constricted passage connecting two abyssal plains which, in the vicinity of the gap, lie at different levels". The Biscay abyssal plain regionally slopes in a southward direction, with its deepest section in the southwest corner, where the slope connects to the Theta gap. Active erosion occurs about $15 \mathrm{~km}$ upslope of the narrowing between the structural highs (Laughton, 1960, 1968), and creates initial incisions of up to $300 \mathrm{~m}$ and later incisions of about $100 \mathrm{~m}$ at points further along the current's course. The LDW water mass, which makes up this overflow ( $>3450 \mathrm{~m}$ water depth), penetrates into the North Atlantic through the Discovery Gap on the western flank of the Madeira-Tore Rise (Haynes and Barton, 1990; McCartney, 1992; Van Aken, 2000), and veers northward along the Galicia margin as a near-bottom flow (Paillet and Mercier, 1997; Van Aken, 2000). A cyclonic recirculation cell occurring above the Biscay Abyssal plain deflects the current poleward however, with a velocity near the continental margin of $1.2( \pm 1.0) \mathrm{cm} / \mathrm{s}$ (Dickson et al., 1985; Paillet and Mercier, 1997) (Fig. 3).

\subsection{Processes at the interface between water masses}

A pycnocline represents a layer with maximum gradient of density, which can be sharp and well defined, or diffuse with a gradual transition from one water mass to the other (Fig. 1). Turbulent mixing of water masses caused by tides (or other processes) can disrupt the pycnocline, whereas stratifying processes (e.g., regional positive buoyancy flux at the surface) maintain it. The relative balance between these two factors defines the structure of the pycnocline in different regions and at different times. The interface often tilts in one dominant direction (e.g., Reid et al., 1977) but can be locally and temporarily displaced by eddies (e.g., Piola and Matano, 2001; Arhan et al., 2002, 2003) and internal waves. Energetic current patterns associated with internal waves and eddies at the interface between water masses (Reid et al., 1977) strongly affect the seafloor (e.g., Hernández-Molina et al., 2009; Hernandez-Molina et al., 2011; Preu et al., 2013) through erosion and re-suspension (Dickson and McCave, 1986; Cacchione et al., 2002; Puig et al., 2004; Shanmugam, 2013a, 2014).

Some water masses circulating around the Iberian margins have remarkable density contrasts (Figs. 4 and 5). The exchange flow through the Strait of Gibraltar exhibits these contrasts for example, as do the base and top boundaries of the MOW (Serra et al., 2010a), which enhanced during cold (i.e.; glacial) periods (Schönfeld et al.,

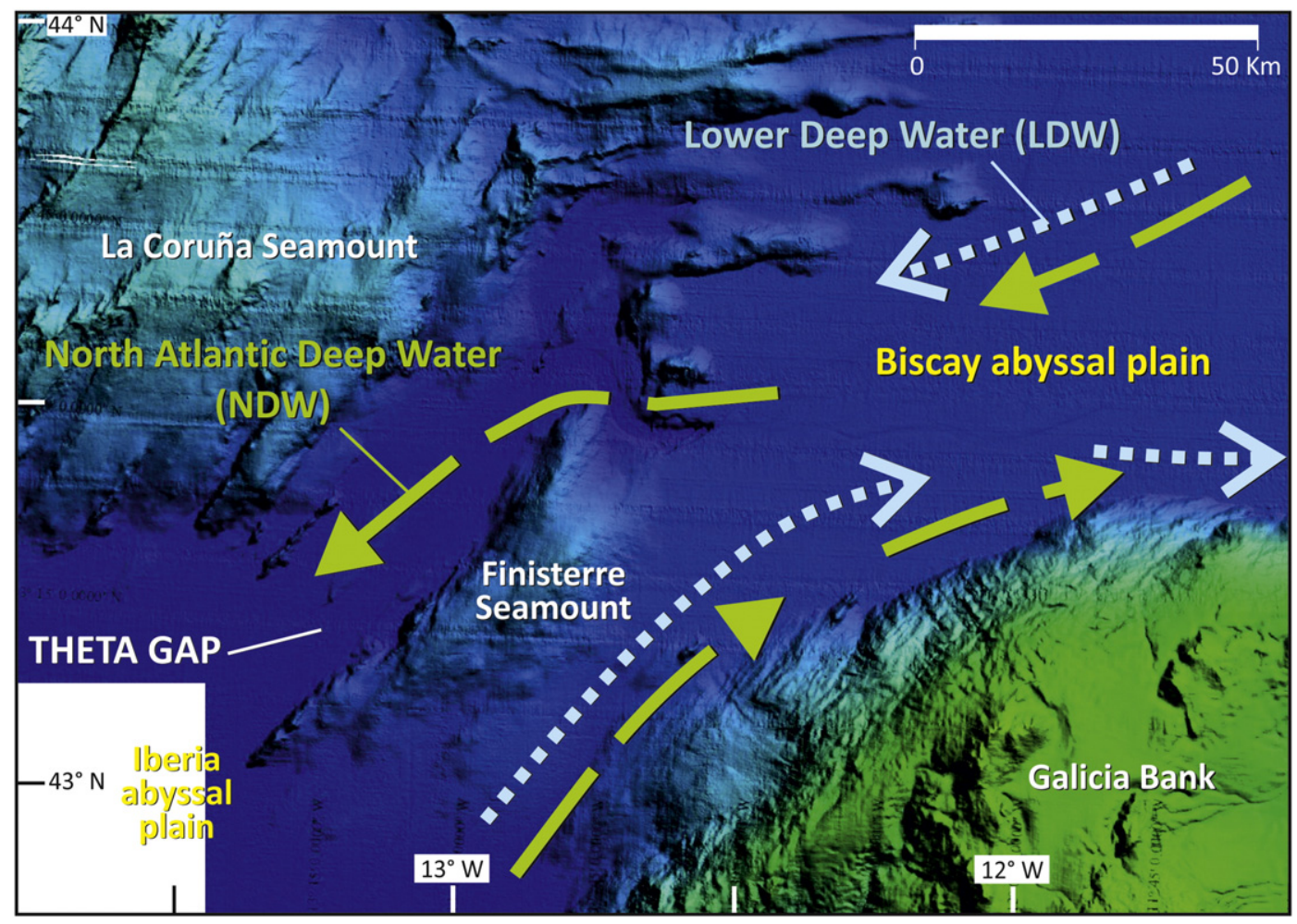

Fig. 3. Main morphologic features around the Theta Gap showing the regional water mass circulation. 


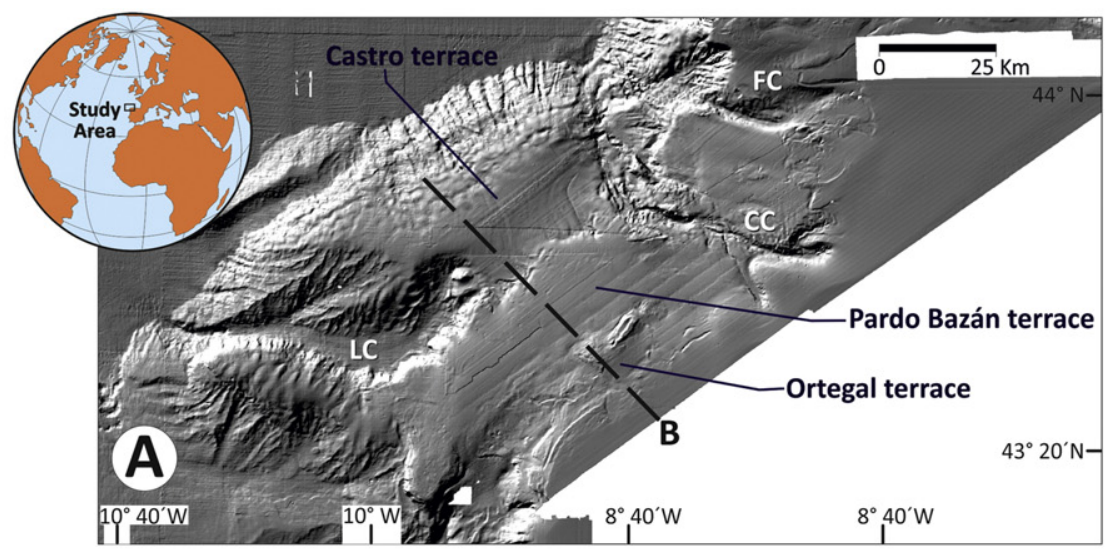

SE / NW

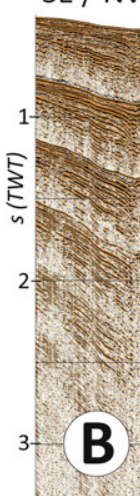
- ES
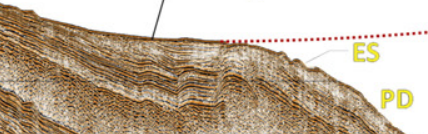

ENACW $\sim 0.4 / 0.6 \mathrm{Km} \cdots$

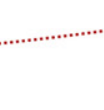

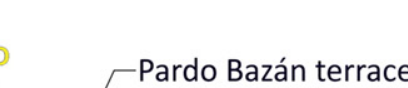

\section{Pardo Bazán terrace}

Mow

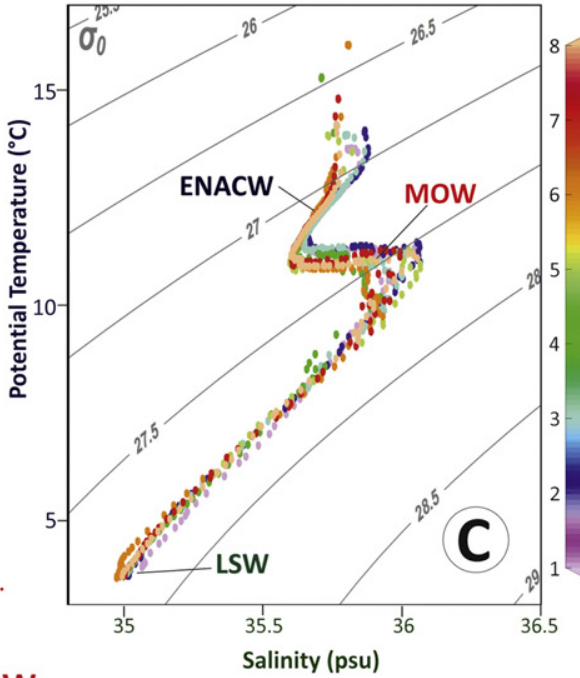

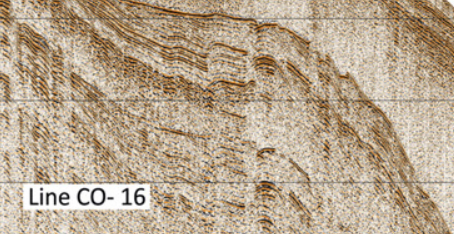
$10 \mathrm{~km}$

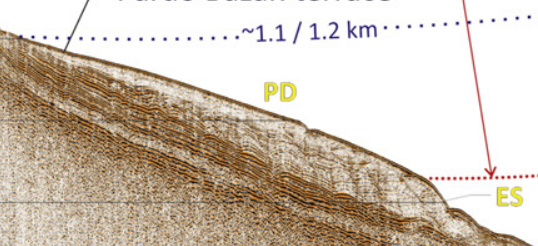

(1)

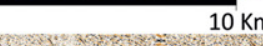
MOW (glacial?)
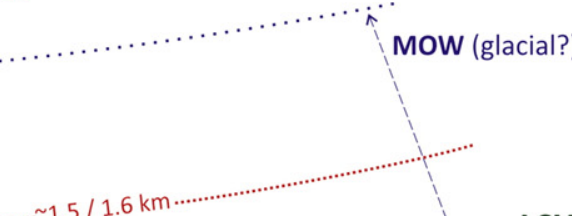

PD
Castro terrace
LSW

Eastern North Atlantic Central Water

MOW $=$ Mediterranean Outflow Water

LSW = Labrador Sea Water

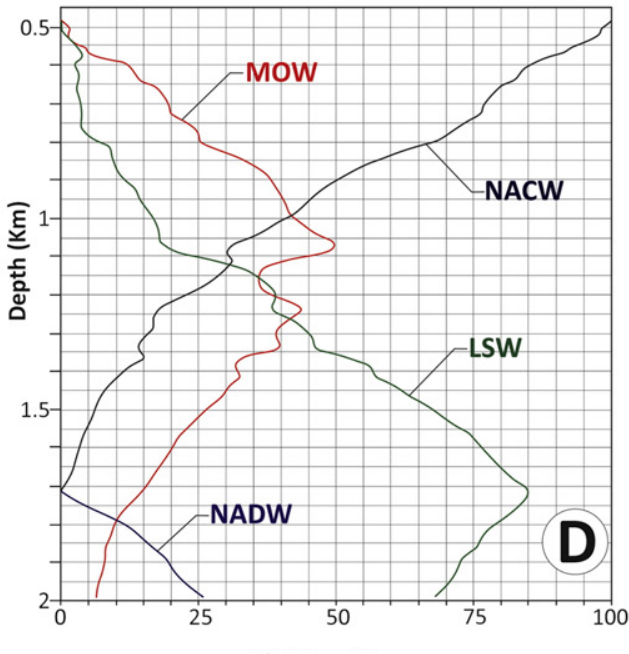

$\%$ Water Mass

NACW = Eastern North Atlantic Central Water

ES $=$ Erosional surface

$\sim 2.5 \mathrm{~km} \cdots \cdots \cdots, P D=$ Plastered drift

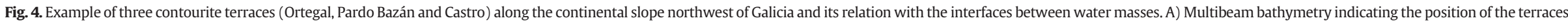

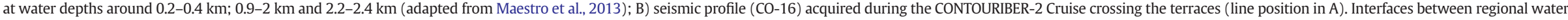

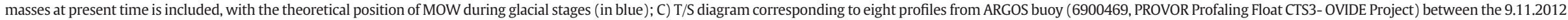
to 18.01.2013 (from Sánchez González, 2013); D) Water masses percentage in the adjacent area to the contourite terraces (from Sánchez González, 2013). 

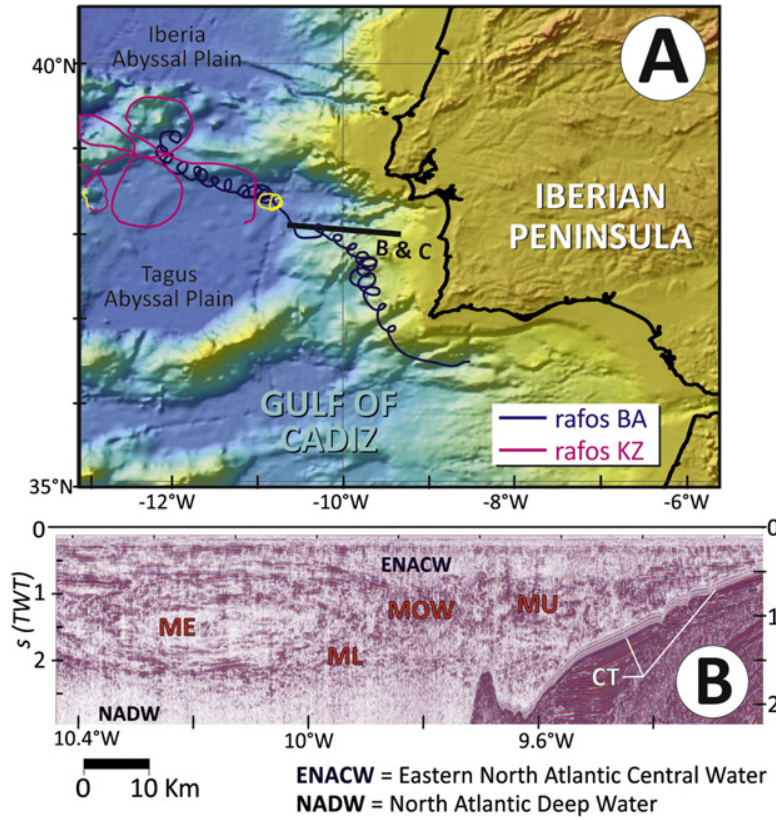
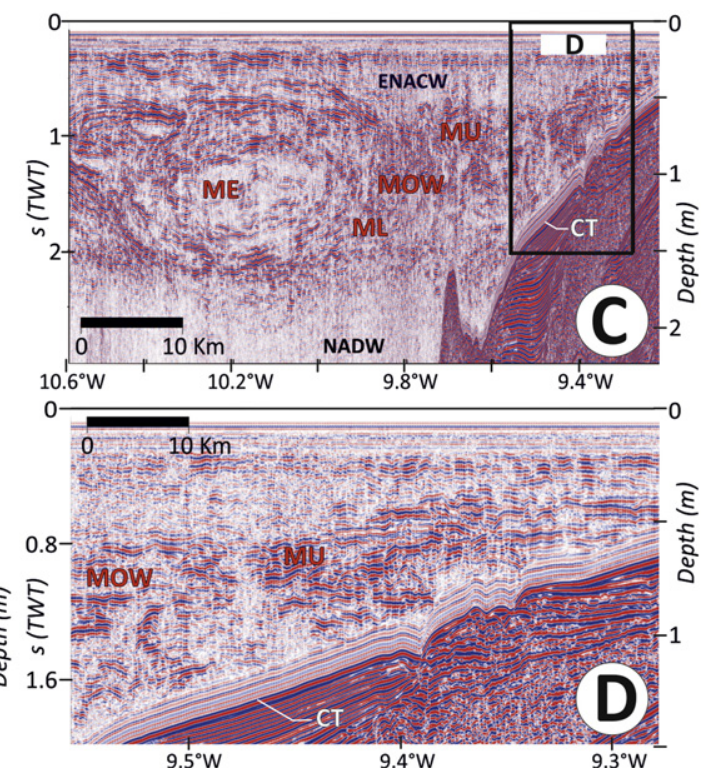

$9.5^{\circ} \mathrm{W}$

$9.4^{\circ} \mathrm{W}$

$9.3^{\circ} \mathrm{W}$

ME $=$ MOW eddies
MU = Mediterranean upper core

ML = Mediterranean lower core

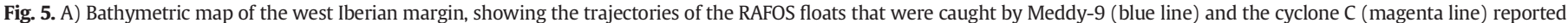

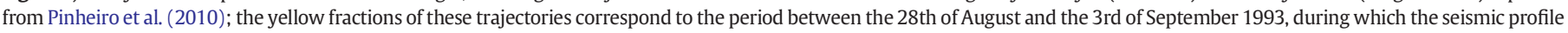

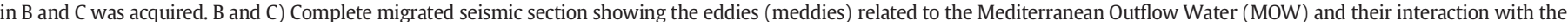

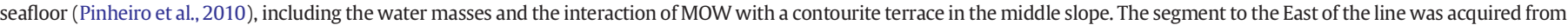

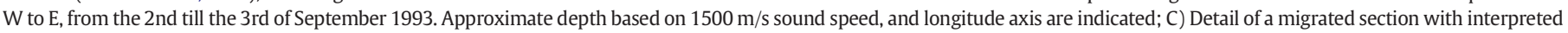

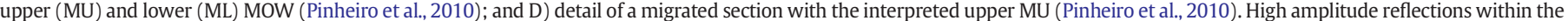
profiles, especially to the upper and lower boundaries of MOW and meddies are indicative of density contrast surfaces in the water column.

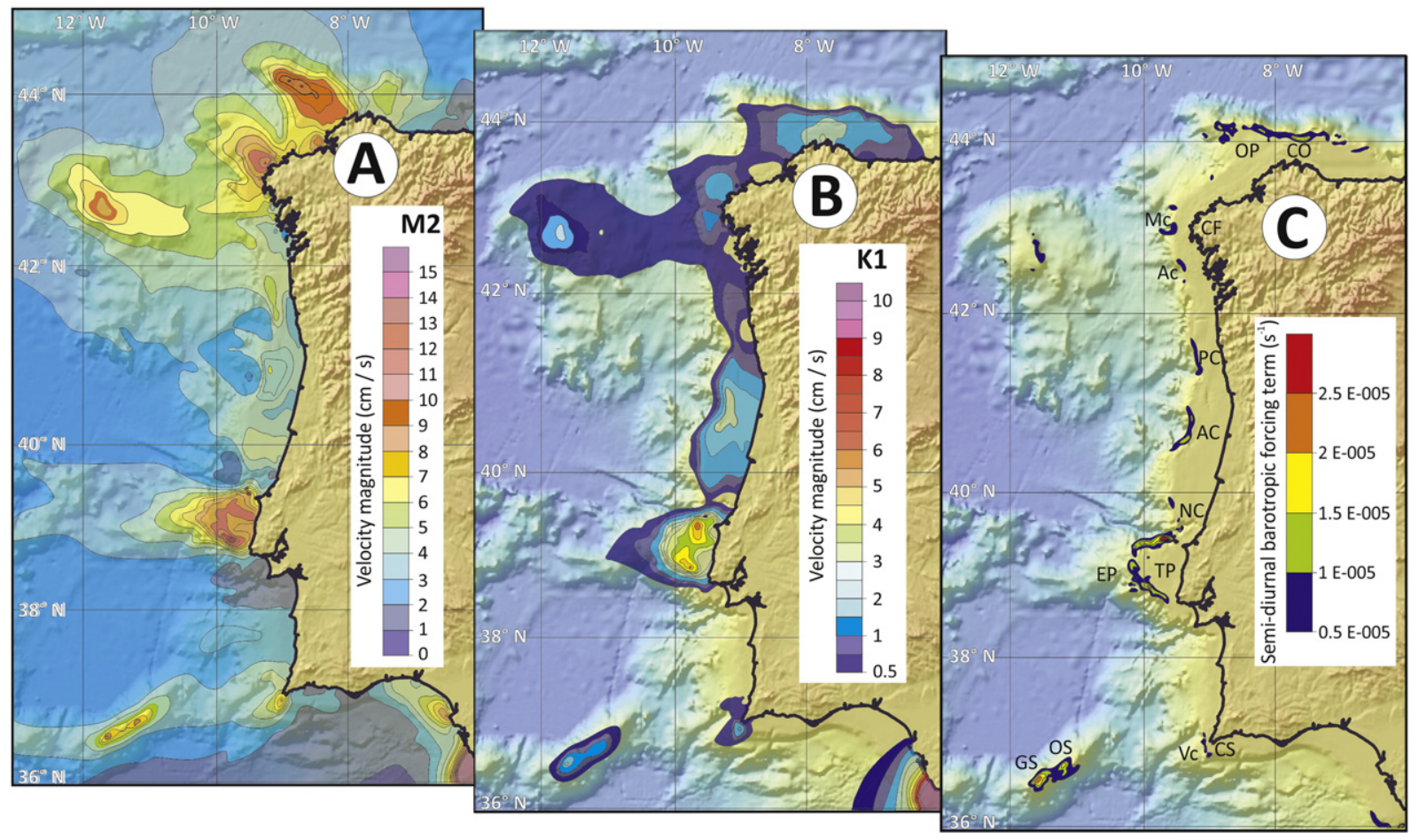

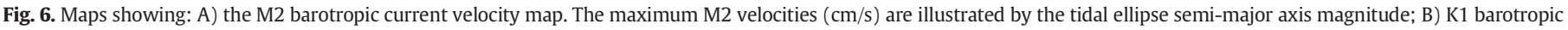

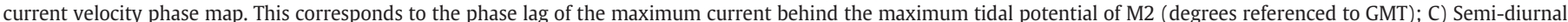

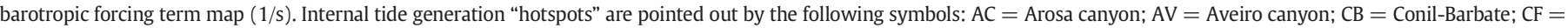

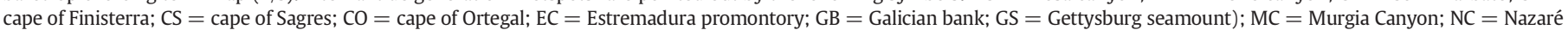
canyon; OP = Ortegal promontory; OS = Ormonde seamount; PC = Porto canyon; TP = Tagus Plateau; Vc $=$ S. Vicente canyon (from Quaresma and Pichon, 2013). 

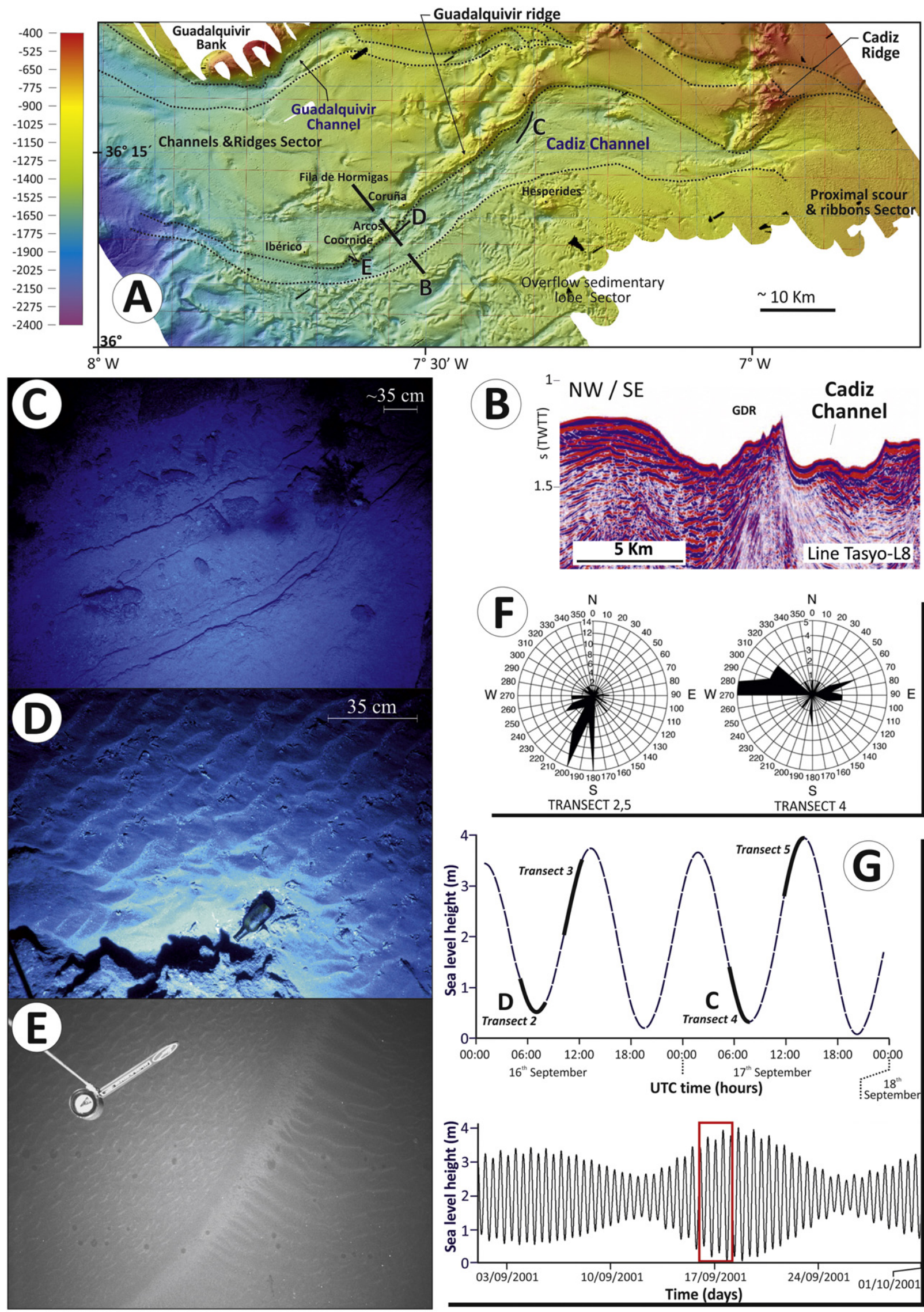

TRANSECT 2,5
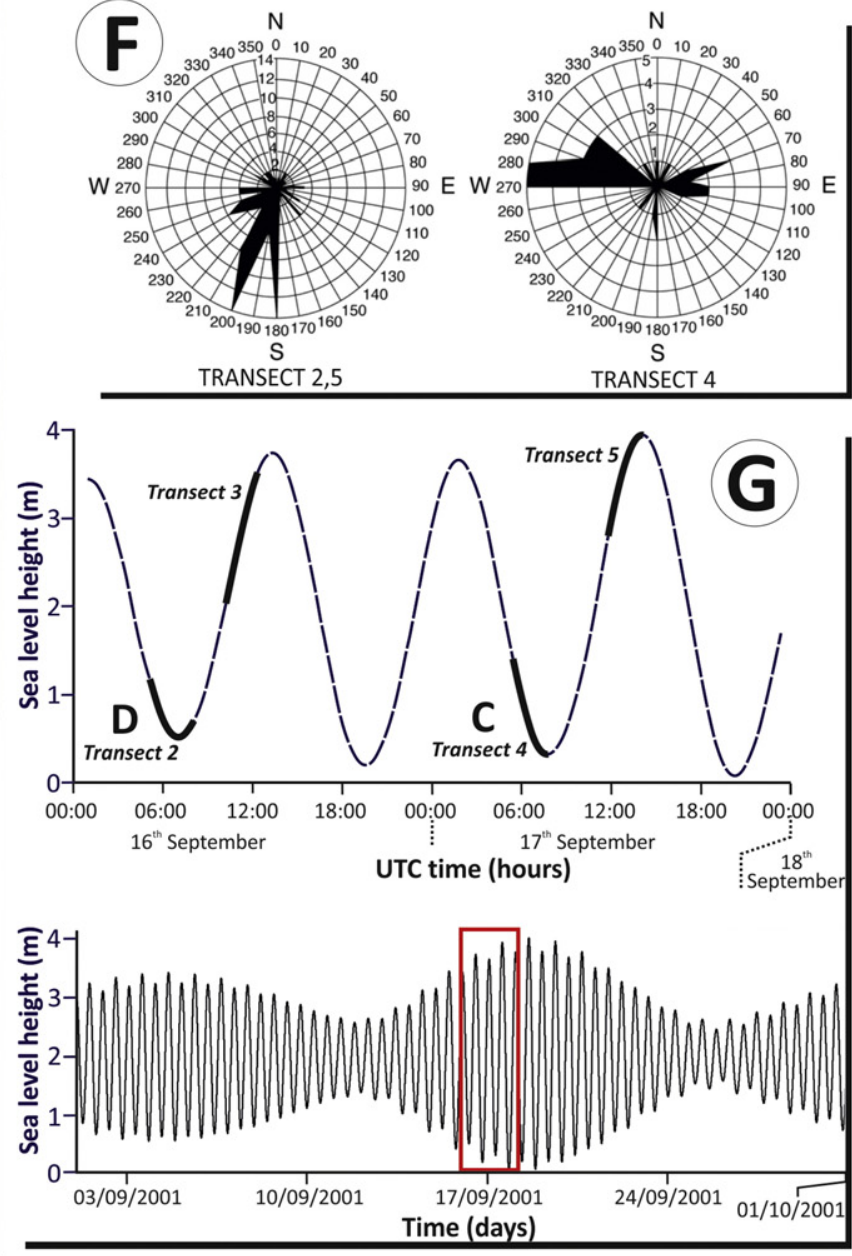
2003; Voelker et al., 2006; Toucanne et al., 2007; Rogerson et al., 2012). The associated currents indicate a relationship between the position of the interface and the development of large contourite terraces (Hernández-Molina et al., 2009; Hernandez-Molina et al., 2011; Preu et al., 2013; Rebesco et al., 2014). Several examples of this relationship have been described along the Iberian margins in the Alboran Sea (Ercilla et al., 2002, 2016), Gulf of Cádiz (Hernández-Molina et al., 2014); Portuguese Margin (Fig. 4, Pinheiro et al., 2010; Llave et al., 2015b); Galician margin (Hanebuth et al., 2015); and Cantabrian Sea (Fig. 4, Maestro et al., 2013; Sánchez González, 2013).

\subsection{Deep-water tidal currents}

Surface tides are mostly driven by the ocean's response to the gravitational fields of the Sun and the Moon. Surface tides are considered barotropic tides because their associated currents are mainly depthindependent (Fig. 1). Tidal signals consist of the superposition of several harmonics (tidal constituents) with the principle lunar semi-diurnal frequency ( $\mathrm{M}_{2}$ tidal constituent; $12.42 \mathrm{~h}$ ) exerting the strongest global effects in agreement with the tide-generating potential theory (Kantha and Clayson, 2000b). Tidal energy may be transferred to baroclinic modes in stratified fluids, thus generating baroclinic tides (Fig. 1). Baroclinic tides can dissipate tidal energy by transferring motion along distant features. Both barotropic and baroclinic tides influence the bottom water circulation in deep-water environments (Dykstra, 2012). Tidal currents change direction periodically with time, describing an elliptical hodograph usually aligned along bathymetric contours in the ocean interior. Tidal energy tends to dissipate, and hence, to exert a stronger effect on continental slopes within submarine canyons and adjacent areas (e.g., Shepard, 1976; Shepard et al., 1979; Viana et al., 1998; Kunze et al., 2002; Garrett, 2003; Shanmugam, 2012a, 2013b; Gómez-Ballesteros et al., 2014; Gong et al., 2013, 2015) and within certain contourite channels (Stow et al., 2013a). Shanmugam (2012a) has proposed that barotropic tidal currents affect land- or shelf-incising canyons connected to estuaries or rivers. Baroclinic tide currents affect slope-incising canyons but do not clearly connect to major rivers or estuary systems. Inversion of bottom current directions due to tidal influence occurs outside these canyons (Kennett, 1982; Stow et al., 2013a). Deep-marine tidal bottom current velocities range from 25 to $50 \mathrm{~cm} / \mathrm{s}$ but can reach $70-75 \mathrm{~cm} / \mathrm{s}$, and exhibit periods of up to $24 \mathrm{~h}$ (Shanmugam, 2012a).

According to both in situ measurements (tidal gauges) and numerical models, the most important harmonic affecting the Atlantic Iberian margins is $\mathrm{M}_{2}$ (sea-level amplitudes between 100 and $180 \mathrm{~cm}$, Fig. 6), followed by $\mathrm{S}_{2}(12.00 \mathrm{~h}, 30-50 \mathrm{~cm})$ (Alvarez Fanjul et al., 1997). A typical spring/neap tidal modulation of 14.8 days (the fortnightly tidal cycle) thus affects Iberian coastal areas. The regional surface tide dynamics around the Atlantic Iberian Peninsula is part of the amphidromic system that characterises the semidiurnal tidal waves in the North Atlantic (Cartwright et al., 1980), where a barotropic Kelvin wave propagates northward along the western Iberian coast with a phase speed close to $900 \mathrm{~km} / \mathrm{h}$. The wave diffracts eastward in the Cantabrian Sea and its amplitude increases-g steadily shoreward. Kelvin wave dynamics predict counter clockwise tidal ellipses aligned parallel to the coast. This simple model adequately approximates observed propagation directions (e.g., the largest phase lags in the Cantabrian Sea, Alvarez
Fanjul et al., 1997), observed and simulated wave amplitudes, which maximize along the northern coast, and open ocean dynamics. The model, however, does not adequately describe tidal current variation in the shelf/slope region where baroclinic tides start playing a significant role and the cross-shore movement becomes increasingly important. Marta-Almeida and Dubert (2006) concluded that bathymetric irregularities exert a major influence on the velocity field wherein steepened areas of the slope amplify tidal currents, orthogonally polarising tidal ellipses along bathymetric contours. Bottom features can therefore theoretically change the S-N orientation of tidal currents. Quaresma and Pichon (2013) have recently shown that the cross-shelf velocity component over the slope and shelf can supersede the alongshelf velocity component, giving rise to clockwise rotation of tidal currents. The ellipse eccentricity decreases as a function of the slope gradient. Along the Mediterranean area of the Iberian margins, tidal currents only exert significant affects in the Alboran Sea (Garcia Lafuente and Cano Lucana, 1994), where phases increase eastward. The velocities of semidiurnal components decrease from a few $10^{-2} \mathrm{~m} / \mathrm{s}$ to $10^{-3} \mathrm{~m} / \mathrm{s}$ in the Algero-Provençal Basin (Albérola et al., 1995).

Both $\mathrm{M}_{2}$ and $\mathrm{S}_{2}$ amplitudes increase from the Gulf of Cádiz to the Bay of Biscay, and exert the dominant influence on tidal wave amplitude and current velocity throughout the shelf (Battisti and Clarke, 1982). Across-shelf, the tidal amplitude decreases offshore with an average gradient of $\sim 0.027 \mathrm{~cm} / \mathrm{km}$. The maximum speeds of $\sim 50 \mathrm{~cm} / \mathrm{s}$ and $20 \mathrm{~cm} / \mathrm{s}$ (in a clockwise direction) for the $\mathrm{M}_{2}$ and $\mathrm{S}_{2}$ ellipses (respectively) occur on the French shelf. The Bay of Biscay confines the tidal wave and forces the generation of noticeable baroclinic tides that amplify the semidiurnal constituents as the barotropic tidal wave impinges the French Armorican shelf. Velocities are much smaller around Iberia, with maxima of 5 and $2 \mathrm{~cm} / \mathrm{s}$ for the respective $M_{2}$ and $S_{2}$ ellipses (Quaresma and Pichon, 2013), and exhibit strong along-shore spatial variability. The $\mathrm{O}_{1}$ and $\mathrm{K}_{1} \mathrm{di}-$ urnal constituents are also present ( 8 and $6 \mathrm{~cm}$ amplitude, respectively), and cause the observed diurnal inequality of the tide.

Although the observed tidal currents are small (rarely $>20 \mathrm{~cm} / \mathrm{s}$ ) around Iberia, they are the primary driving force behind strong, high-frequency baroclinic activity, which does not affect other coastal regions. The combination of regional, barotropic tidal velocities and steep bathymetry amplifies this effect into "hotspots", which occur along the Atlantic margins of Iberia (Quaresma and Pichon, 2013, Fig. 6C). Hotspot areas include the Extremadura and Ortegal Spurs as well as the Gettysburg and Ormonde seamounts. The Cádiz Contourite Channel, in the central sector of the Gulf of Cádiz, offers one of the best examples of sandy bedforms created directly by the dynamic interaction of tidal currents and seafloor (Stow et al., 2013a, Fig. 7). The narrowness of this channel (2-12 km) amplifies bottom tidal currents due to a funnelling effect. Current metre data from this area show a strongly directional, westerly MOW moving at speeds of $1 \mathrm{~m} / \mathrm{s}$ at the instrument height of $78 \mathrm{~m}$ with a clear periodicity in its velocity, suggestive of a semi-diurnal tidal signal and of a spring/neap cycle (Fig. 8A).

\subsection{Deep-sea storms}

Benthic storms (also known as deep-sea storms or abyssal storms) refer to intermittent, strong, bottom-intensified currents affecting the

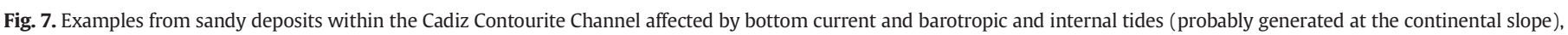

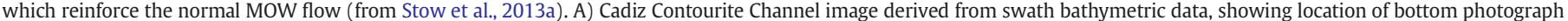

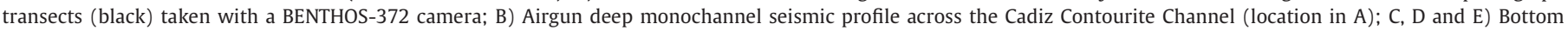

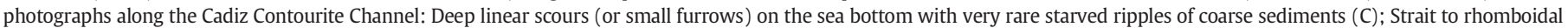

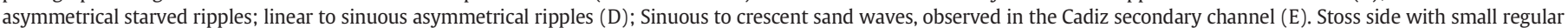

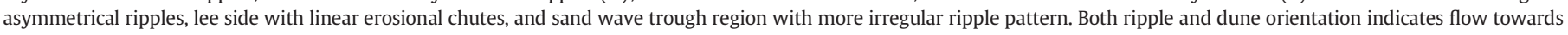

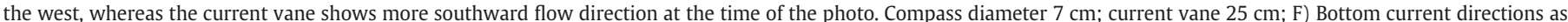

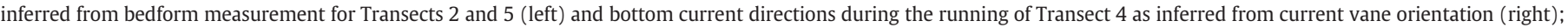

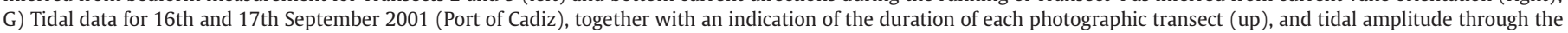
month of September 2001 (down). 
seafloor (Fig. 1). The HEBBLE (High Energy Benthic Boundary Layer Experiment; Hollister et al., 1980) first documented the existence of benthic storms while investigating the response of the cohesive seafloor to high-stress events. During these storms, bottom current velocity can increase by a factor of 2-5 times (average $15-20 \mathrm{~cm} / \mathrm{s}$ with peaks of $>43 \mathrm{~cm} / \mathrm{s}$ ) over a period of a few days ( 2 to 25 days) to several weeks. Benthic storms occur at a frequency of about 8 to 10 events per year (Holger, 1987). Benthic storm related flows can rework up to several millimetres of seafloor sediment per event. Entrainment of the bottom nepheloid layer or bottom boundary layer by turbulent and diffusive mixing favours rapid resuspension of particulate matter (Gardner and Sullivan, 1981; Hollister and McCave, 1984; Nowell and Hollister, 1985; Gross and Willimans, 1991). During the occurrence of these storms, the benthic boundary Layer (BBL) increases in thickness from a few metres up to $70 \mathrm{~m}$, and in turbidity up to values of $5 \mathrm{~g} / \mathrm{l}$ (Tucholke, 2002). Other mechanisms for benthic storms hypothesise sediment plumes descending from continental slopes and rapid input of organic-rich phytodetritus from plankton blooms in surface waters (Richardson et al., 1993; Puig et al., 2013). In this latter case, organicrich detritus draping the seafloor is easier to flocculate and maintain in suspension. Detailed studies of suspended particulate matter throughout the BBL indicate that sediment concentration depends on the interplay of several factors, including initial concentration in suspension, turbulence, height of entrainment, velocity field, transport distance and settling velocity of the particles. Gross and Willimans (1991) emphasized three physical processes, which modulate deep-sea storm events. These include turbulence in the boundary layer, eroded sediment at the sediment-water interface and suspended sediment winnowed by the flow. Any one of these three lines of evidence defines a storm event (Gross and Willimans, 1991).

Benthic storms play an important role in the erosion, transport and redistribution of bottom sediments (Hollister et al., 1980; Nowell and Hollister, 1985; Hollister, 1993). Once disturbed by the erosional effects of increased bottom shear, sediments may be transported by bottom currents and deposited in quiet regions downstream (Gardner and Sullivan, 1981; Kennett, 1982; Hollister and McCave, 1984; Flood and Shor, 1988; Bearmon, 1989; Von Lom-Keil et al., 2002). These currents may travel over long distances, constrained by the Coriolis force and semi-diurnal tides parameters. Seafloor morphology from large, kilometre-scale features (e.g., seamounts) to smaller, metre-scale features (e.g., sediment waves) can affect this transport (Rebesco and Camerlenghi, 2008).

The occurrence of benthic storms relates in part to the formation of large eddies within the water column due to the interaction between major wind-driven surface currents and the bottom component of THC. Areas of the ocean with a highly variable sea surface show more frequent benthic storm activity (Richardson et al., 1993; Faugères and Mulder, 2011). The kinetic energy of these eddies can extend to depths of $>3000 \mathrm{~m}$ and thus change the magnitude and direction of bottom currents. Benthic storms also occur in the presence of strong, permanent bottom currents, and in areas where seafloor sediments are easily flocculated into suspension (Richardson et al., 1993). Due to the limited information concerning benthic storms, however, uncertainties persist in regards to their initiation and driving mechanism.

As major sediment entrainment processes, benthic storms play an important role in contourite development. Benthic storms also disturb benthic communities (Gross and Willimans, 1991). Regions subjected to intense deep-sea storms show significant erosion of the continental slope and evidence of large submarine slides (Pickering et al., 1989; Gao et al., 1998; Einsele, 2000).

Only a few examples of deep-sea storms have been documented around Iberia linked to the formation of surface dense waters in the Gulf of Lions and the subsequent deep cascading and open-sea convection process (Font et al., 2007; Palanques et al., 2009; Durrieu de Madron et al., 2013). Some of these events, as the one observed in winter 2009 (Fig. 9), can be exclusively due to deep convection without the accompanying cascading process (Salat et al., 2010; Puig et al., 2012; Stabholz et al., 2013). In the Cantabrian margin, three independent events have been identified at La Gaviera Canyon (Sánchez et al., 2014). The scarcity of information on this type of phenomena could mask their frequency. For example, a current metre moored at around $554 \mathrm{~m}$ water depth in the Gulf of Cádiz may have recorded possible benthic storms (Fig. 8B), but further analysis of these time series observation is required to confirm such interpretation.

\subsection{Eddies}

Instabilities in bottom currents often generate vortices (Serra et al., 2010a) and contribute to long-distance sediment transport and the formation of nepheloid layers (Fig. 1). Eddies occur when a water mass interleaves into a stratified environment, or when current flows meet a seafloor irregularity such as a canyon, seamount or cape (Roden, 1987; Rogers, 1994; Arhan et al., 2002; Serra et al., 2010a). Along some regions of the seafloor, eddy activity spans hundreds of kilometres, as for example, in the Argentine Basin (Cheney et al., 1983; Flood and Shor, 1988; Arhan et al., 2002; Hernández-Molina et al., 2009), the Weddell and Scotia Seas (Hernández-Molina et al., 2008a), the Mozambique slope (Preu et al., 2011), the Gulf of Cádiz and the margins west off Portugal (Serra et al., 2010a).

The best-studied example of eddies around Iberia relate to the MOW (sometimes referred to as meddies). Meddies are low-potential vorticity bodies that rotate clockwise and maintain MOW-type temperature and salinity conditions in their cores for long periods of time (on the order of years). These coherent vortices translate at average speeds of $2-4 \mathrm{~cm} / \mathrm{s}$ and have typical azimuthal velocities of $30 \mathrm{~cm} / \mathrm{s}$ (Fig. 10B). The radial structure of their core velocity resembles solid body rotation (Schultz-Tokos and Rossby, 1991). Meddies have been observed in the Canary Basin (e.g., Armi and Zenk, 1984; Richardson et al., 1989; Pingree and Le Cann, 1993), in the Iberian Basin (Käse et al., 1989; Zenk and Armi, 1990; Schultz-Tokos et al., 1994), off the southern coast of Portugal (Prater and Sanford, 1994; Bower et al., 1997; Serra and Ambar, 2002), off west Portugal (Pinheiro et al., 2010, Fig. 5), and along the northwestern Iberian coast (Paillet et al., 2002). Bower et al. (1997) identified Cape St. Vincent Spur and the Extremadura Promontory as points of origin for meddies. The region adjacent to Cape Finisterre (Paillet et al., 2002), the region of the Portimao Canyon (Serra and Ambar, 2002) and the Gorringe Bank (Serra and Ambar, 2002) are also recognized sites of meddy formation.

The proposed mechanisms for generating these eddies include boundary layer separation of the MOW undercurrent (Bower et al., 1997), baroclinic and/or barotropic instability of the MOW undercurrent (Käse et al., 1989; Cherubin et al., 2000), flow intermittency (Nof, 1991) and topographic effects due to capes (Pichevin and Nof, 1996; Sadoux et al., 2000; Serra et al., 2005) or canyons (Cherubin et al., 2000; Serra et al., 2005). Three factors contribute to the meddy displacements. These include advection by mean flow (Hogg and Stommel, 1990; Dewar and Meng, 1995), the beta-effect or meridional variation of the planetary vorticity (Nof, 1982) and interactions between different eddies (Käse and Zenk, 1996; Serra et al., 2002). This latter mechanism can involve the coupling of cyclones and meddies (Richardson et al., 2000; Carton et al., 2002; Serra et al., 2002). Near their generation sites, meddies may re-suspend sediment and carry it into the open ocean.

Eddies interaction with seafloor could produce local erosion (Hernández-Molina et al., 2008a; Rebesco et al., 2014). In this way some sub-circular depression structures and other erosive features around the Le Danois Bank (Cantabrian Sea, van Rooij et al., 2010) and the Guadalquivir Bank Margin uplift (Gulf of Cadiz, García et al., 2015b, this special issue) have been attributed to the influence of local eddies of the MOW interacting with seafloor irregularities, as slide scars or other local irregularities. 

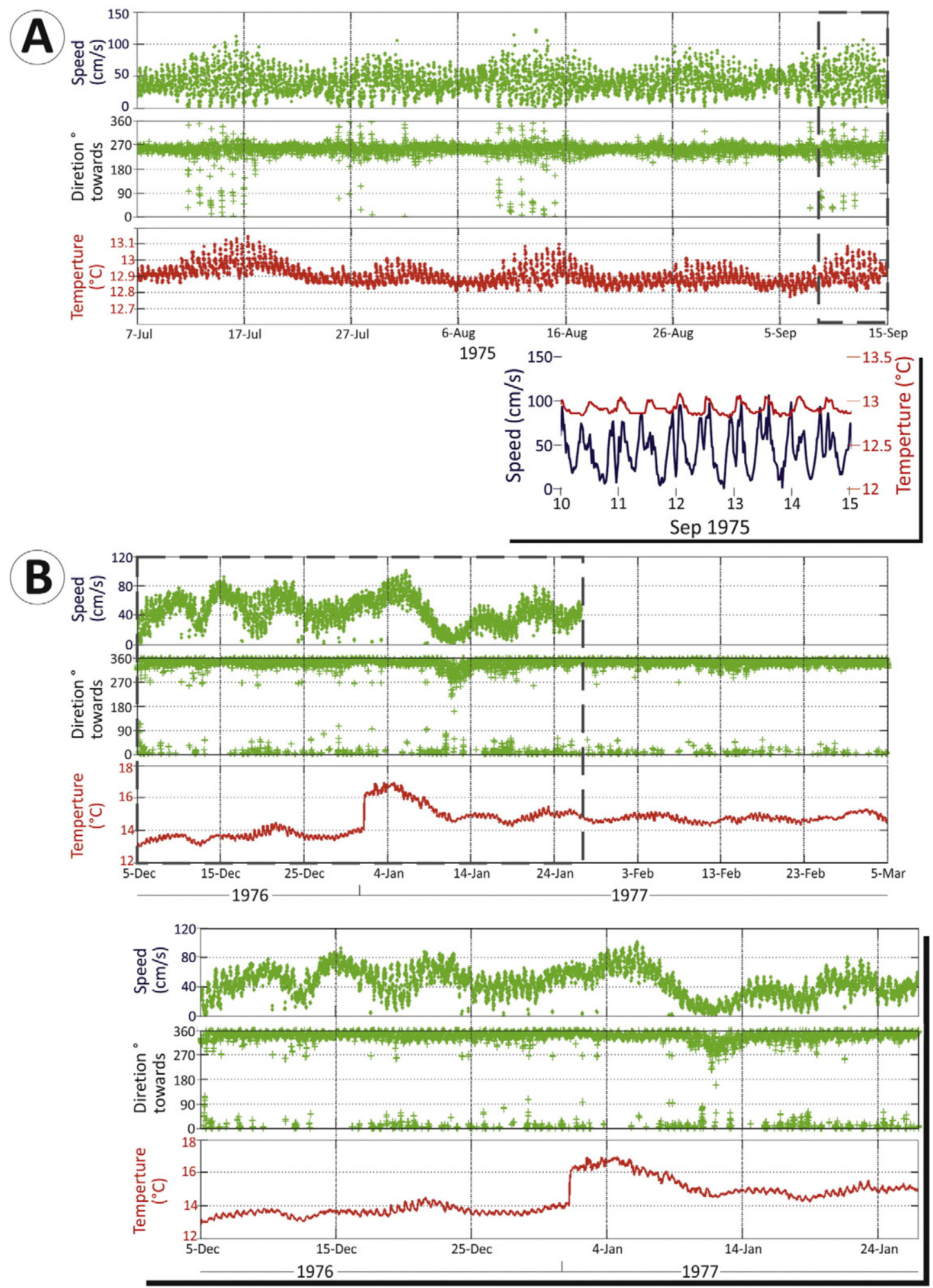

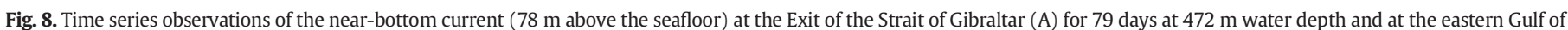

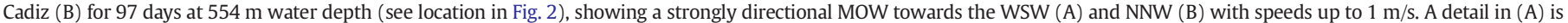

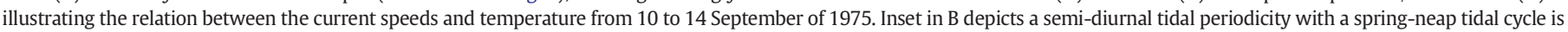

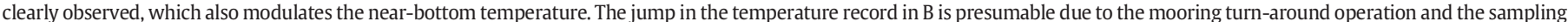

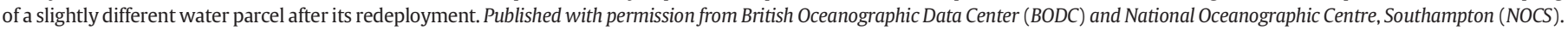

\subsection{Secondary circulation}

Dense water masses usually have main current cores that run parallel to isobaths (Figs. 1 and 10A). The velocity of these cores manifests in contourite erosional features as moats and channels (e.g., McCave and
Tucholke, 1986; Faugères et al., 1993, 1999; Rebesco and Stow, 2001; Stow et al., 2002a, 2009; Rebesco and Camerlenghi, 2008; Faugères and Mulder, 2011). They are often associated with deposition in downslope areas, and erosion in upslope areas. The structure of these features may result from helicoidal flow paths, or clockwise secondary 


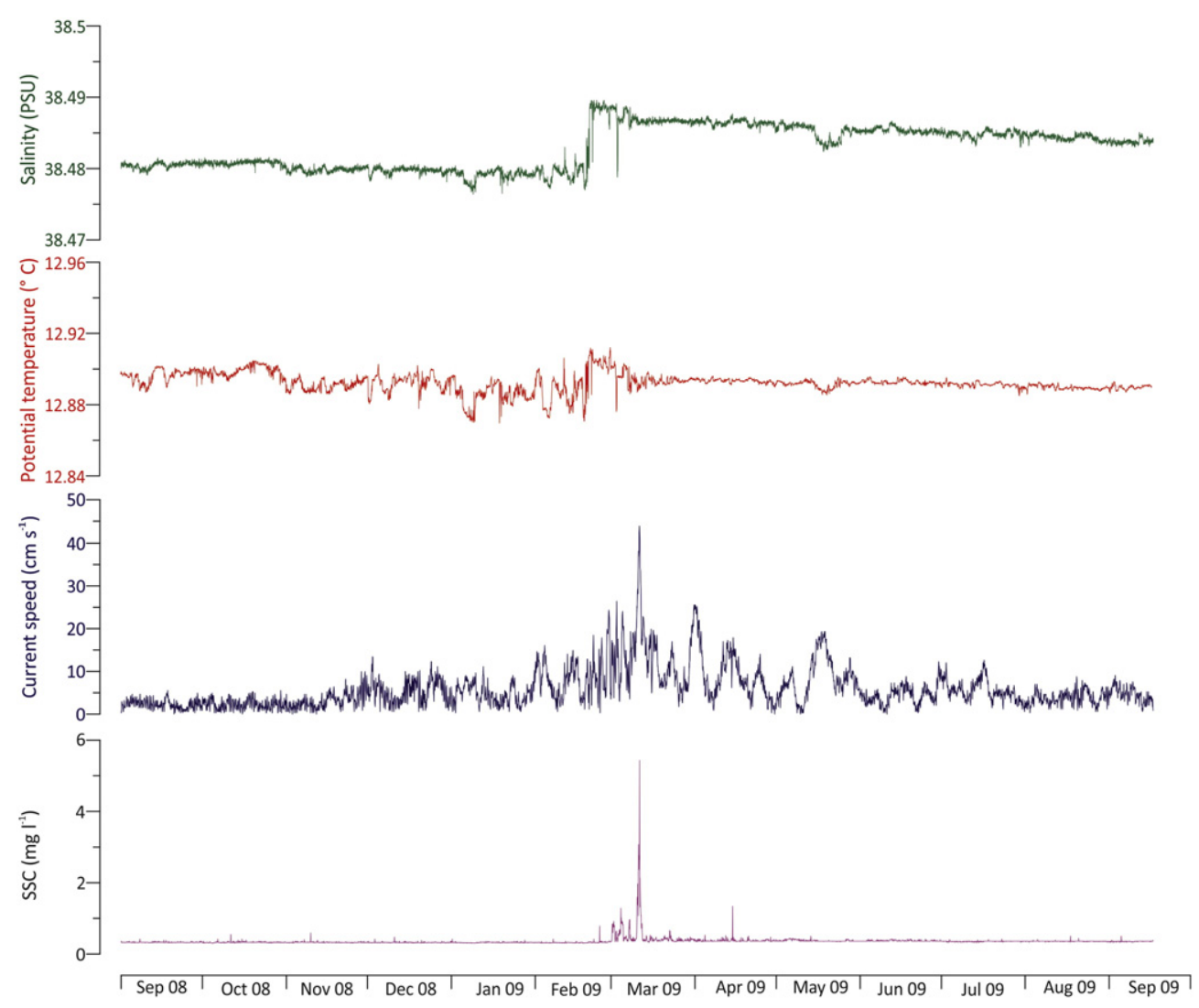

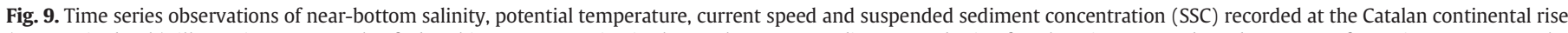

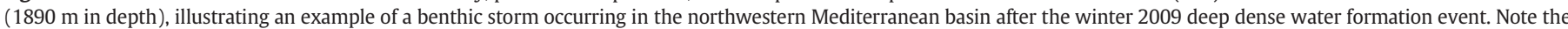

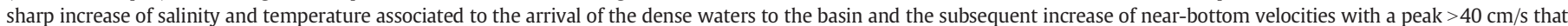
caused resuspension of bottom sediments (modified from Puig et al., 2012).

circulation of the bottom current around the core of the current. These structures are referred to as 'horizontal eddies' in geophysical literature (Davies and Laughton, 1972; Roberts et al., 1974; Roden, 1987; Rogers, 1994; McCave and Carter, 1997; Hernández-Molina et al., 2008a, 2008b; Zenk, 2008). Although seafloor features, as moats and contourite channels, along the Iberian margins (García et al., 2009; Llave et al., 2015a, 2015b) suggest helicoidal flow, this interpretation requires further analysis of currents and seafloor morphology (Rebesco et al., 2014). These features likely result from the Coriolis effect directing the vortex against the adjacent slope, eroding the right side of the channel and depositing sediment on the left side where the current velocity is lower (Faugères et al., 1999; Llave et al., 2007). The combined effect of bottom friction and the Coriolis effect in the Ekman layer usually results in clockwise secondary circulation in bottom currents (Wåhlin and Walin, 2001; Wåhlin, 2004; Muench et al., 2009; Cossu et al., 2010; Cossu and Wells, 2013).

This type of secondary circulation may occur in the eastern Gulf of Cádiz, near the exit of the Strait of Gibraltar (Fig. 2, Serra, 2004; García et al., 2009; Hernández-Molina et al., 2014). The identification of secondary circulation further suggests its role in generating furrows observed to run oblique relative to the main bodies of the prevailing bottom-currents (Hernández-Molina et al., 2014).

\subsection{Dense shelf water cascades}

Dense shelf water cascades (DSWC; Fig. 1) describe the flow of dense water generated in shelf areas down the continental slope (Simpson, 1982; Killworth, 1983; Ivanov et al., 2004). DSWC are nearbottom gravity flows that develop when cooling, evaporation, freezing and/or salinization in the surface layer formed over the continental shelf causes density-driven flow over the shelf edge. The dense water plume cascades both along and across the slope area according to density, gravity effects, the Coriolis Effect, friction and mixing. Once the density of the water plume matches the density of the surrounding waters the DSWC reaches gravitational equilibrium and becomes an intermediate-depth, neutrally buoyant intrusion (Shapiro and Hill, 1997; Shapiro et al., 2003). Submarine canyons incised into the shelf edge can offer preferential pathways for DSWC (Canals et al., 2006, 2009; Trincardi et al., 2007; Allen and Durrieu de Madron, 2009). This intermittent process affects biogeochemical cycles by re-suspending sediment and transporting significant volumes of minerals and organic matter (Fohrmann et al., 1998; Hill et al., 1998; Puig et al., 2013).

The Gulf of Lions, located in the northeastern sector of the Iberian Peninsula experiences annual DSWC (Millot, 1990, 1999; Durrieu de Madron et al., 2005; Puig et al., 2013). Winter cooling and evaporation, induced by persistent, cold, dry northerly winds (Tramontane and Mistral winds) cause increased density and mixing of coastal waters. This occurs in spite of buoyancy effects from freshwater input of the Rhone River. The prevailing westerly coastal circulation, the narrowing shelf and the topographic constraint of the Cap de Creus peninsula, all facilitate DSWC and sediment transport. These currents develop in the Gulf's southwestern sector, primarily moving through the Lacaze-Duthiers and Cap de Creus submarine canyons, where cascading flows can reach velocities $>80 \mathrm{~cm} / \mathrm{s}$ (Palanques et al., 2006). DSWC events occur from January to April/May with duration of several days, and often begin and/or are enhanced during storms, which cause increases the suspended sediment concentration and generally amplify downcanyon sediment fluxes (Palanques et al., 2008). In very dry, windy and cold periods, such as the 1998-99, 2004-05 and 2005-06 winters, the Gulf developed unusually intensive DSWC that lasted for several weeks (Fig. 11). During these major events, large quantities of water and suspended particles are rapidly advected over depths of hundreds 

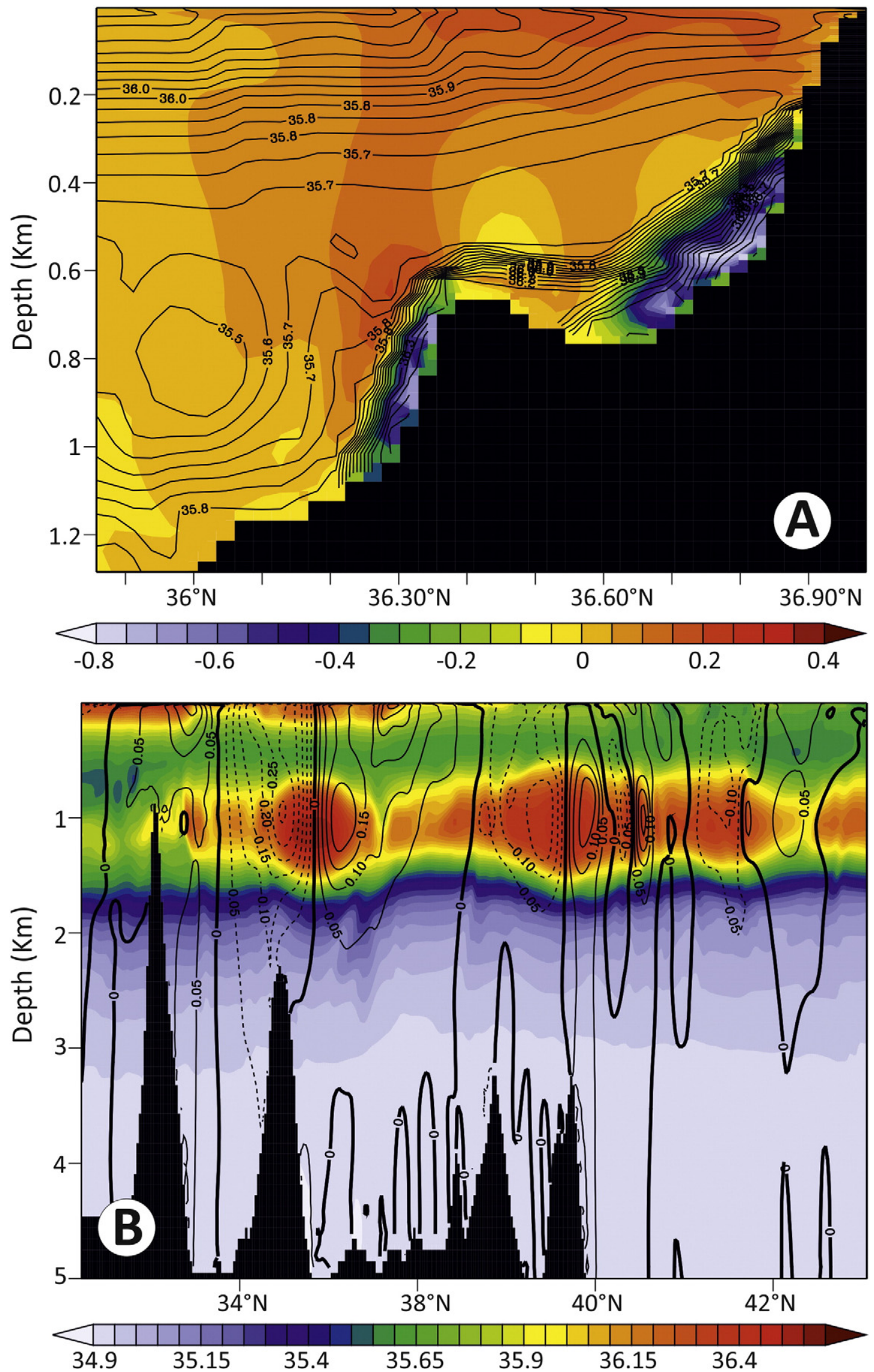

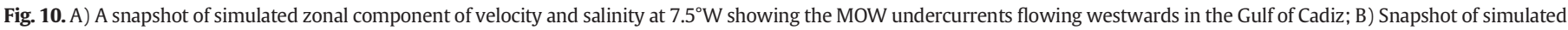

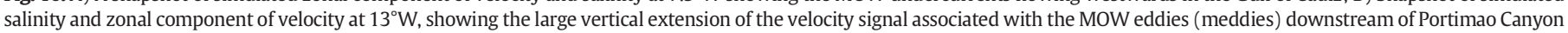
(from Serra et al., 2010a). 

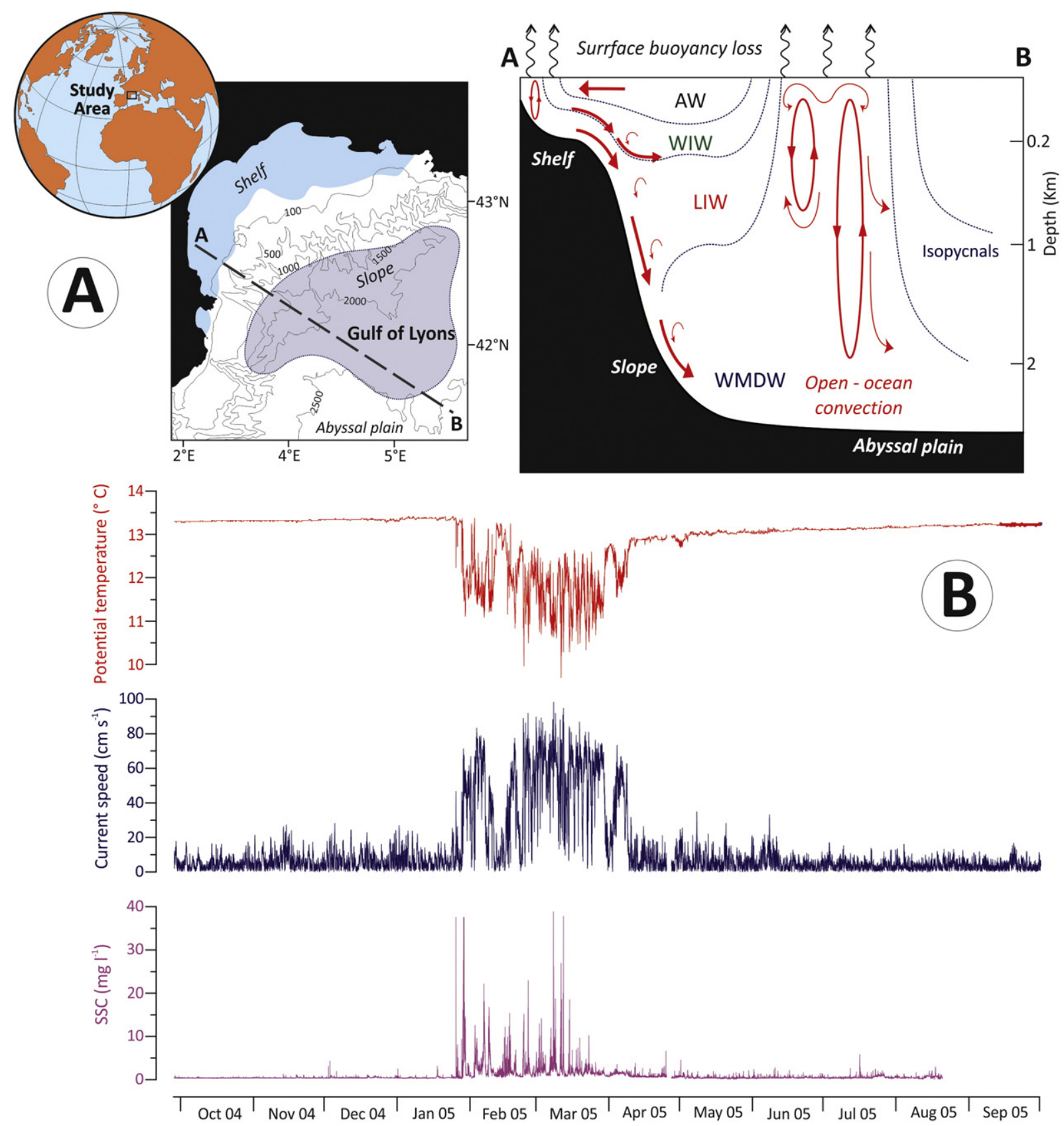

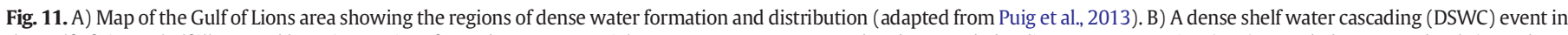

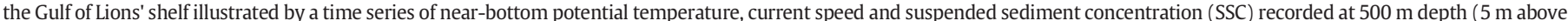

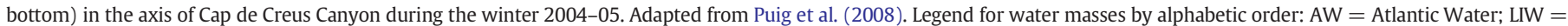
Levantine Intermediate Water; WIW = Western Mediterranean Intermediate Water; WMDW = Western Mediterranean Deep Water.

of metres along submarine canyons, causing erosion of the seafloor and generating sedimentary furrows (Palanques et al., 2006, 2009, 2012; Canals et al., 2006; Puig et al., 2008). The most persistent and penetrative cascading pulses generally follow a multi-step sediment transport mechanism. Sediment is initially transported from the shelf to the upper canyon region. The subsequent cascading pulses re-suspend and redistribute the sediment down-slope, generating massive sand beds at the canyon head region (Gaudin et al., 2006). At depths of $1500 \mathrm{~m}$, where the Cap de Creus submarine canyon widens, most of the dense water and suspended sediment leaves the canyon and flows along the northern Catalan continental margin as a contour current (Palanques et al., 2012). Continuous monitoring of cascading events in the Cap de Creus canyon has recognized a large degree of inter-annual variability in DSWC, as well as its complex interactions with concurrent storms and down-welling transport (Ribó et al., 2011; Martín et al., 2013; Rumín-Caparrós et al., 2013).

\subsection{Internal waves and solitons}

Internal waves typically have much lower frequencies (periods from several tens of minutes to days) and higher amplitudes (up to hundreds of metres) than surface waves (Fig. 1). Internal waves can also propagate vertically through the water column transferring energy in either direction between shallower and deeper levels (Shanmugam, 2012b, 2013a, 2014, Fig. 12). These phenomena occur throughout the oceans, as evident in temperature, salinity and current measurements (Kantha and Clayson, 2000a, 2000b). They appear as surface roughness 


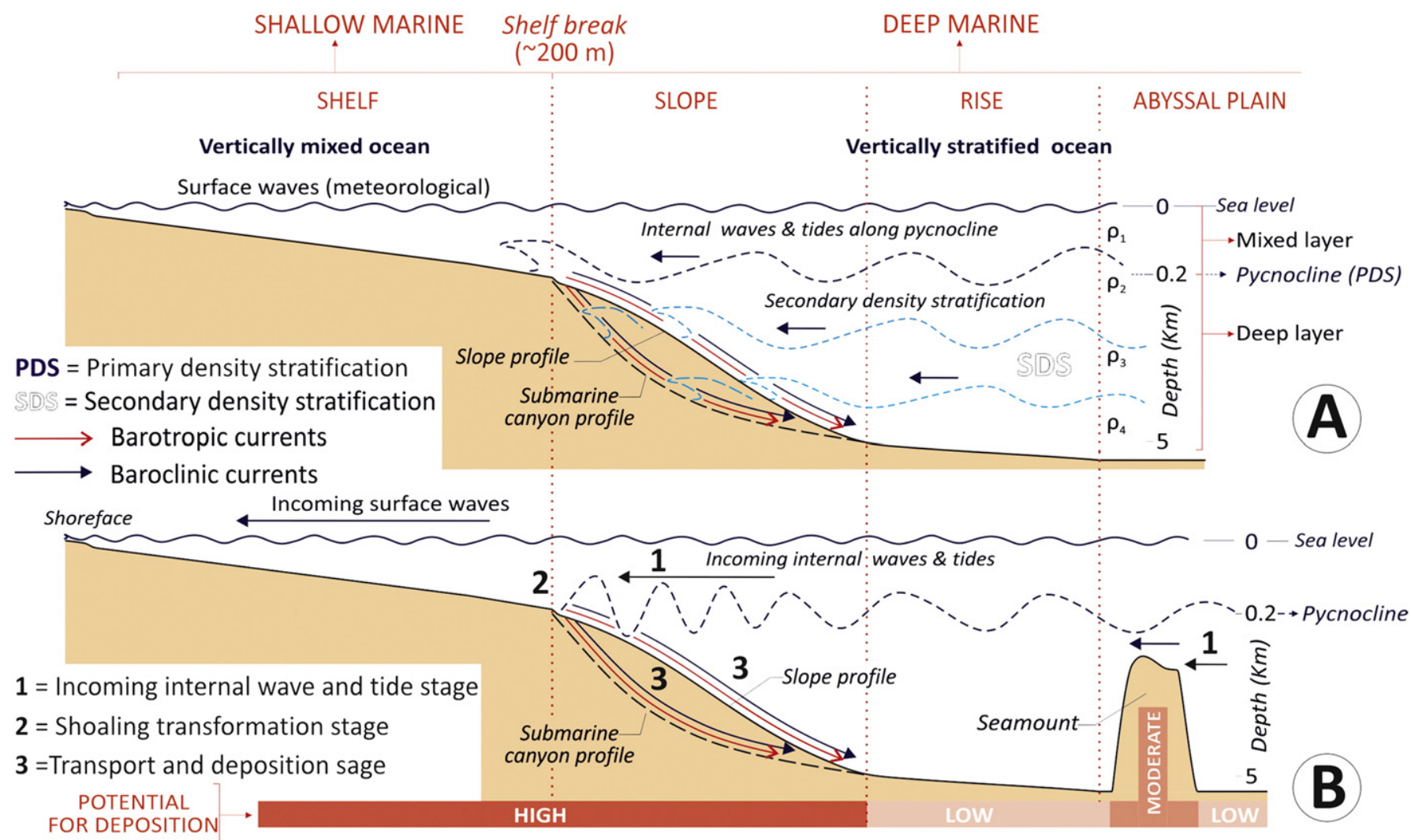

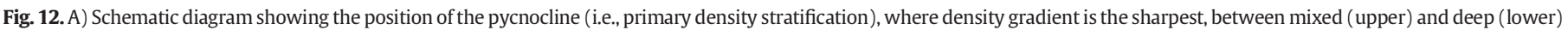

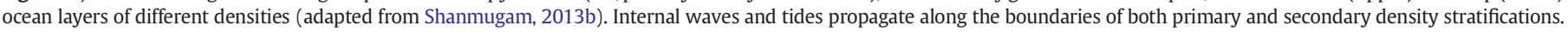

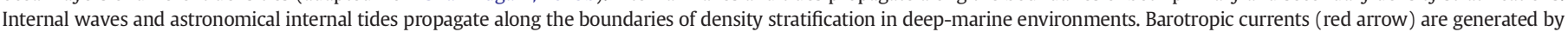

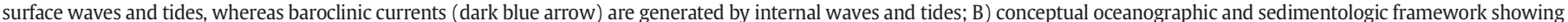

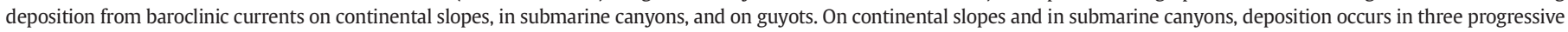

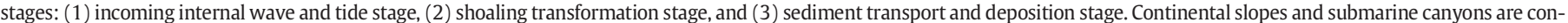

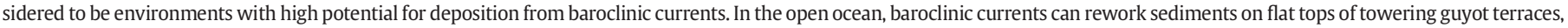
without the need for the three stages required for the deposition on continental slopes (From Shanmugam, 2012a, 2012b, 2013b).

produced by interference between the current velocity and the upper layer background dynamics (Bruno et al., 2006).

Internal waves occur in stable, stratified fluids due to the restoring action of the buoyancy forces on water parcels displaced from their equilibrium position (Fig. 12). Interfacial waves on the density interfaces offer a good example of internal waves (Gill, 1982). When the density interface is disturbed, waves radiate horizontally along the interface if the vertical density gradient is high enough (Shanmugam, 2012a, 2013a, 2013b). In continuously stratified waters internal waves travel along paths (wave characteristics) that run oblique to the horizontal plane. The exact angle is a function of the frequency of the internal wave, the buoyancy or Brunt Väisälä frequency $N$ and the Coriolis parameter $f$ (Gill, 1982). Perturbation of a region with high $N$ values, such as steepened segments of the pycnocline, tend to travel rather horizontally along the pycnocline (Shanmugam, 2012a, 2013a, 2013b), whereas if the vertical density gradient is more uniform the internal perturbation may radiate at an angle relative to the vertical (Baines, 1982). The frequencies of the free internal waves are confined to frequencies between $f$ and $N$. In the upper ocean at middle and high latitudes, $N$ typically exceeds $f$ by one or two orders of magnitude. At low frequencies approaching $f$, Earth's rotational effects are critical and the waves are referred to as near-inertial internal waves (Garrett, 2001; Puig et al., 2001; van Haren et al., 2013). At higher frequencies approaching $N$, rotational effects become negligible. In the deep oceans at middle and high latitudes, $f$ and $N$ are comparable. The weak stratification at the abyssal regions prevents the formation of high-frequency internal waves (e.g., only low frequency close to $f$ stands). In latitudes approaching the equator, $f$ approaches zero. The diminished rotational component affects the internal wave structure and dynamics primarily at very low frequencies.

As mentioned above internal waves occur due to the disruption of horizontal density surfaces within a stratified water column. The most usual perturbing mechanism is the interaction between currents and the bottom topography (Fig. 12) in regions where it changes more or less abruptly, as ridges, banks, slopes, shelf breaks, etc. (Farmer and Armi, 1999; Shanmugam, 2013a, 2013b). Barotropic tidal currents are often behind this type of forcing. Other forces that generate vertical perturbations also produce internal waves by the same mechanism. These types of forces may derive from the wind stress on the sea surface or from currents induced by other types of barotropic waves, such as continental shelf waves or edge waves (Bruno et al., 2006).

The topographic perturbations often start with a single wave or soliton, which disintegrates in rank, ordered internal wave trains (Vlasenko et al., 2009) of lesser wavelengths and shorter periods, relative to the original internal wave that approached the pycnocline (Apel et al., 1995). These secondary perturbations exhibit relatively high amplitudes and have induced currents that reach intensities of $200 \mathrm{~cm} / \mathrm{s}$.

Internal waves have been described in coastal areas of California (Emery, 1956), in the Sea of Japan (Navrotsky et al., 2004), the Indian Ocean (Santek and Winguth, 2005), the Bay of Biscay (Baines, 1982); Messina Strait (Brandt et al., 1997); Gibraltar Strait (Brandt et al., 1996; Bruno et al., 2006) and on other areas along the Iberian margins (Puig et al., 2004; Hernandez-Molina et al., 2011; Hernández-Molina et al., 2014; Van Haren et al., 2013; Ribó et al., 2015a). 


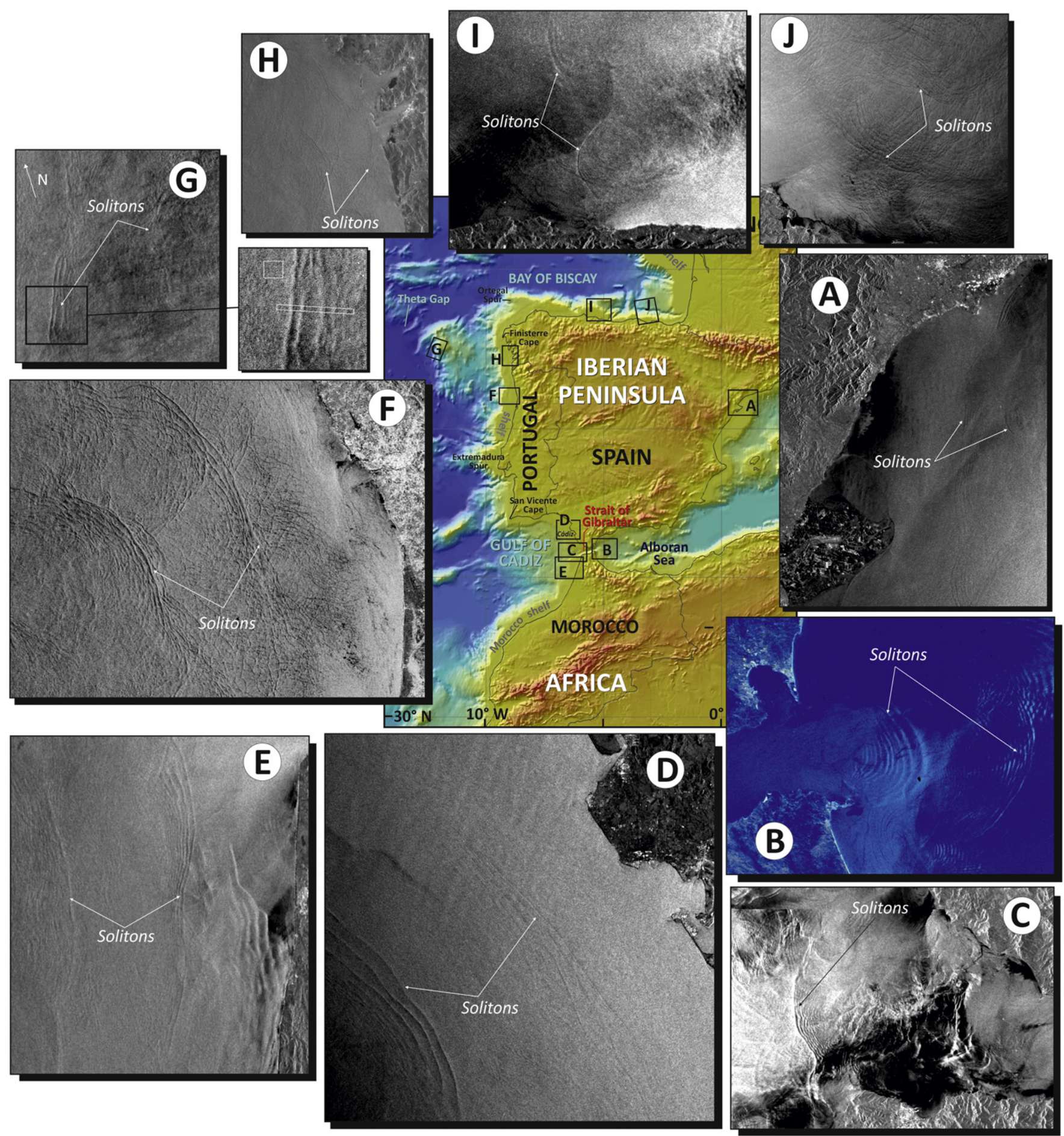

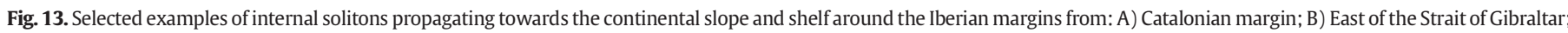

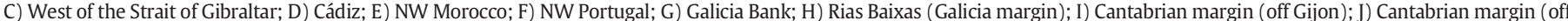

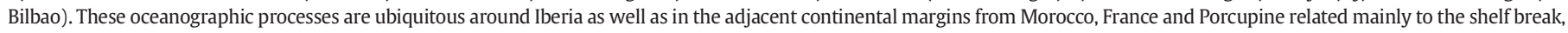

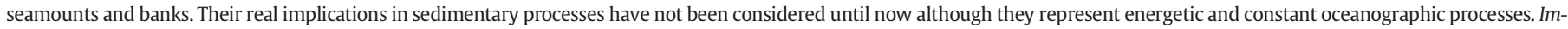
ages are synthetic aperture radar images [from Apel, 2004 and EOLi (Earth Observation Link, European Space Agency, http://earth.esa.int/EOLi/EOLi.html)].

The energy associated with internal waves is particularly important close to the continental margins (maximum horizontal velocities up to $200 \mathrm{~cm} / \mathrm{s}$ and vertical velocities of $20 \mathrm{~cm} / \mathrm{s}$, Shanmugam, 2012a, 2012b, 2013a). Internal waves may act as the primary mechanism in alongslope and across-slope processes, maintenance of intermediate and bottom nepheloid layers (McCave, 1986; Dickson and McCave, 1986; Cacchione et al., 2002; Puig et al., 2004) and in the erosion of contourite terraces (Hernández-Molina et al., 2009; Preu et al., 2013).
High amplitude internal wave generation in the Strait of Gibraltar strongly affects the Iberian margins. These processes primarily occur around the Camarinal Sill and other minor sills nearby where the tidetopography interaction generates internal bores that evolves into the well-shaped wave trains mentioned above (Armi and Farmer, 1988; Farmer and Armi, 1988; Vlasenko et al., 2009; Sánchez-Garrido et al., 2011. See also Fig. 13), with amplitudes of 50 to $100 \mathrm{~m}$ and wavelengths of 1 to $4 \mathrm{~km}$ (Armi and Farmer, 1988; Farmer and Armi, 1988; Brandt 


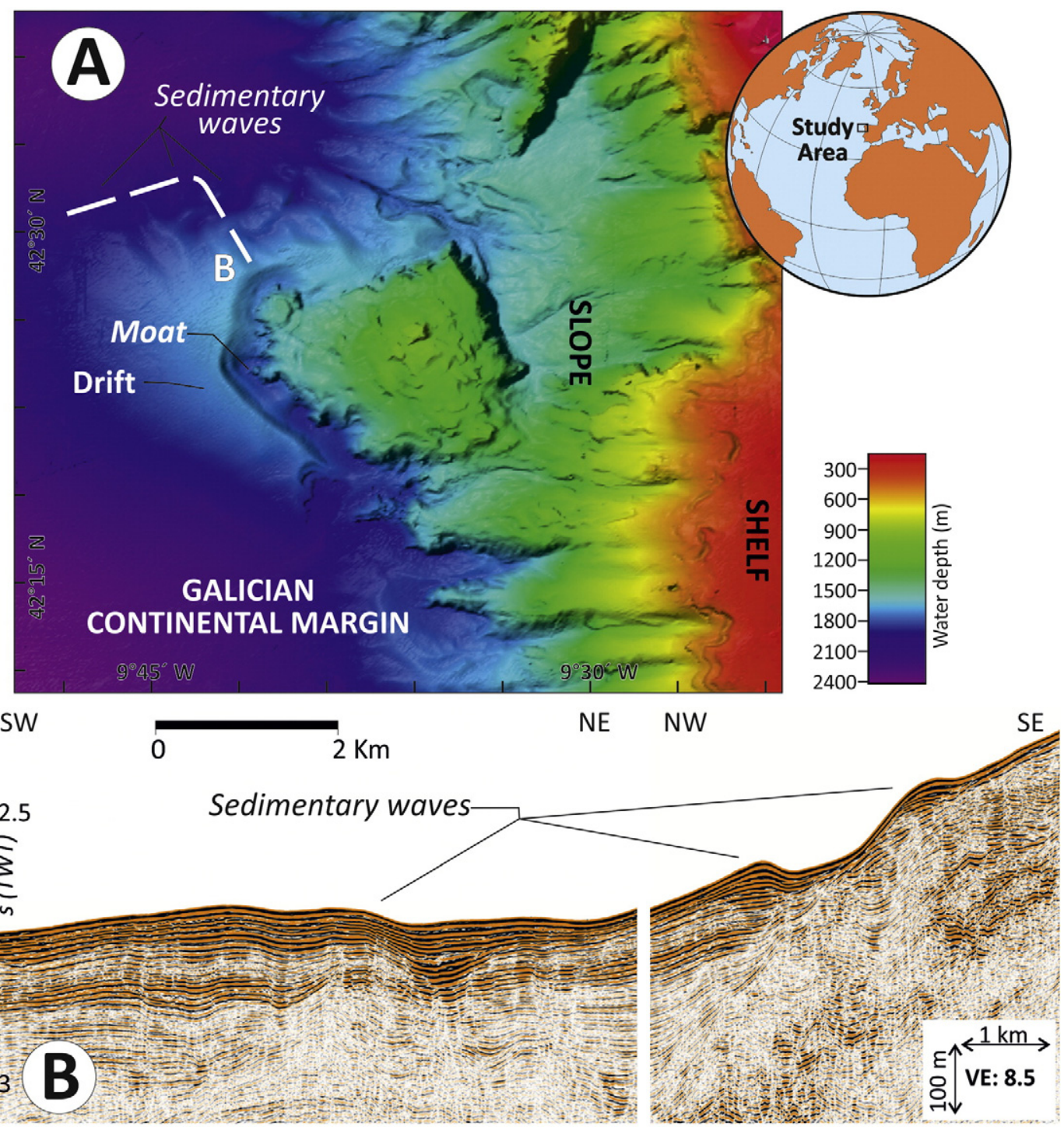

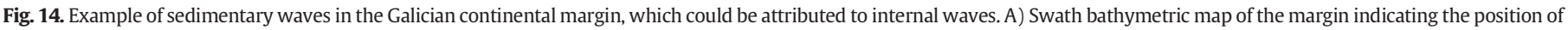

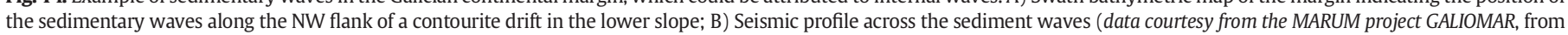
Hanebuth et al., 2012).

et al., 1996; Jackson, 2004). The wave trains extend at least $200 \mathrm{~km}$ into the Western Mediterranean and persist for more than 2 days before dissipating (Apel, 2000; Jackson, 2004) (Fig. 13). Solitons and internal waves have been observed in many other areas along the Iberian margins (Fig. 13), including the Gulf of Cádiz, the West Coast of Portugal and the Galician and Cantabrian margins (Pingree et al., 1986; Pingree and New, 1989, 1991; Correia, 2003; Apel, 2004; Jackson, 2004; Azevedo et al., 2006; Pichon et al., 2013); at the NW flank of Le Danois at the Cantabrian margin (Gonzalez-Pola et al., 2012); and the Gulf of Valencia continental slope (van Haren et al., 2013; Ribó et al., 2015a), where several large fields of sediment waves intrepreted as being generated by the interaction of internal waves with the seafloor develop (Ribó et al., 2015b, 2015c). Solitons also frequently occur along the shelf break of the Iberian margins (Apel, 2004). Although present knowledge about internal waves and solitons are limited, many features along the Iberian slope could be related to their effect, as sedimentary waves on the Galician continental margin (Fig. 14, Hanebuth et al., 2012, 2015). Internal waves amplify its influence within submarine canyons (e.g., Shanmugam, 2012a, 2013a, 2013b; Puig et al., 2014), contributing to higher velocity bottom currents within the canyon (Quaresma et al., 2007; Sánchez et al., 2014) and reworking sandy deposits, as in the Gaviera Canyon, Cantabrian margin (Fig. 15, Gómez-Ballesteros et al., 2014). Sedimentary waves are very common at certain depths within submarine canyons, and some of them are reworked sedimentary waves as those described in the Setubal, Nazaret and Cascais Canyons (Arzola et al., 2008; Lastras et al., 2009) and interpreted as being due to the action of turbiditic processes (Fig. S2). To what extent these sedimentary waves could be related to the action of internal waves on submarine canyons is unknown. The fact is that the role of internal waves on submarine canyons, gullies, etc., has been overlooked and should be considered in future multidisciplinary works.

\subsection{Other-related traction current}

Other processes could generate traction currents in deep-marine settings (Fig. 1), such as the tsunami-, rogue- and cyclone-related currents (Shanmugam, 2006, 2012a). Tsunami waves carry energy through the water, but do not displace the water horizontally, nor do they transport sediment. During the transformation stage, however, tsunami waves erode shallow water zones and incorporate sediment into the incoming wave. Tsunami-related traction currents can thus transport large concentrations of sediment in suspension (Abrantes et al., 2008; Shanmugam, 2006, 2012a). Tsunamis are also important mechanisms for triggering sediment failures, as the advancing tsunami wave front 

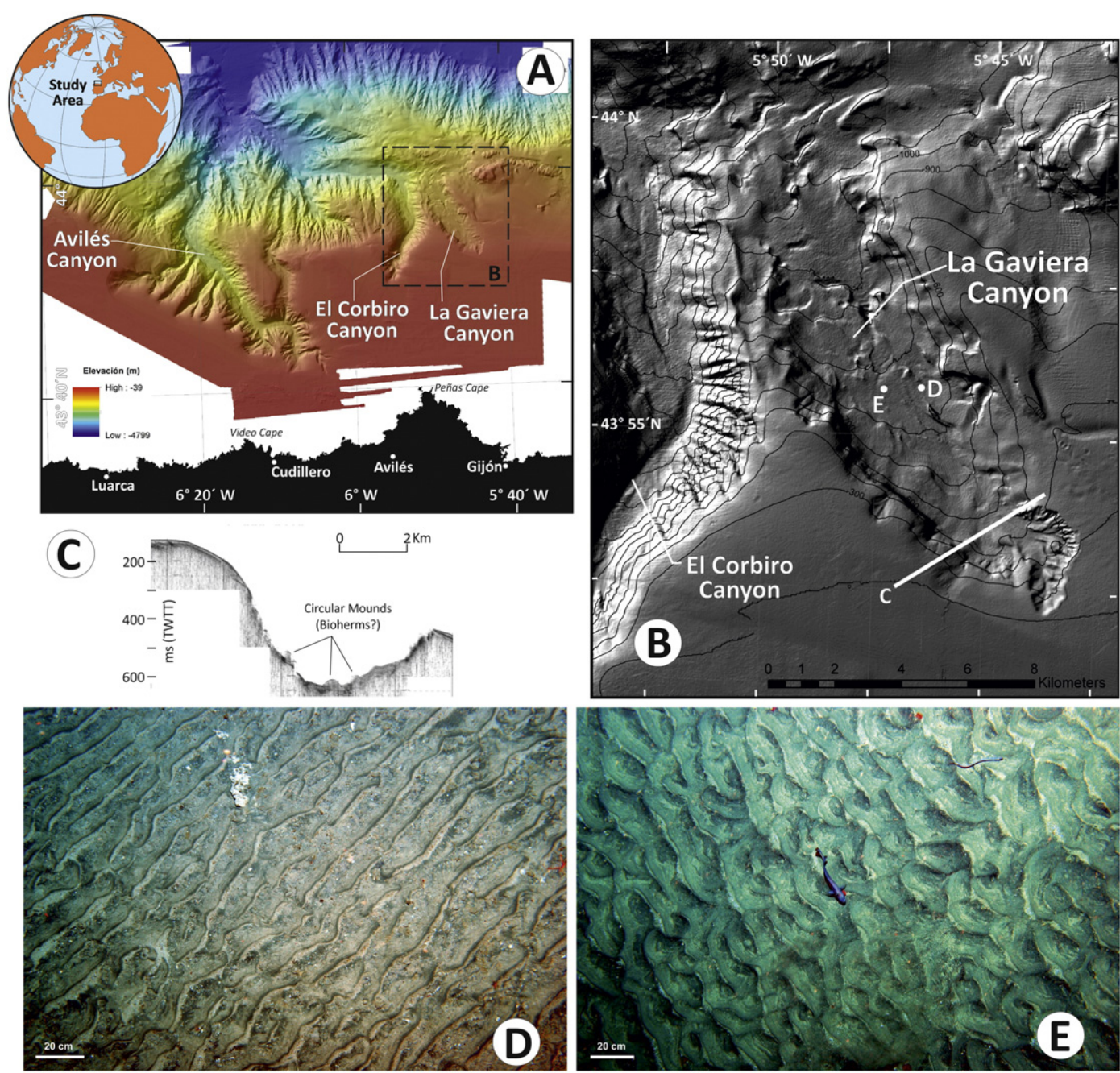

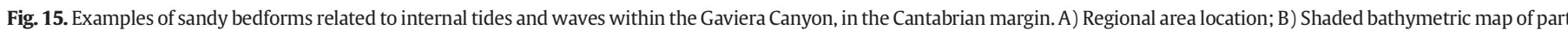

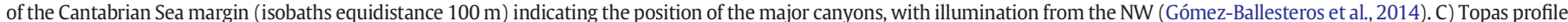

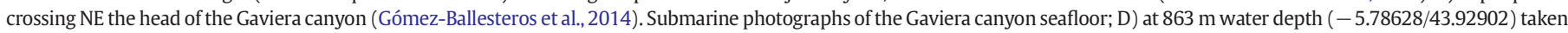

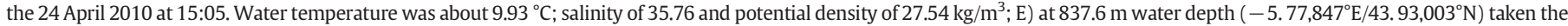
26 April 2010 at $15: 41$. Water temperature was about $9.95^{\circ} \mathrm{C}$; salinity of 35.75 and potential density of $27.53 \mathrm{~kg} / \mathrm{m}^{3}$ (Photo taken by F. Sánchez, IEO).

can generate large hydrodynamic pressures on the seafloor that overwhelm slope stability factors (Wright and Rathje, 2003). Similar to tsunamis, rogue waves (also known as freak waves, killer waves, monster waves, extreme events, abnormal waves, etc.) and cyclone waves are categorized as intermittent processes, which can trigger bottom currents and generate large hydrodynamic pressures on the seafloor that produce submarine mudflows and slope instabilities (Shanmugam, 2012a). As such, they accelerate deep-water sedimentation and/or rework previous deposits.

The southern Iberian margins are seismically active due to the convergent plate boundary between Eurasia (Iberian sub-plate) and Africa (Nubian sub-plate) (Zitellini et al., 2009). Earthquakes have triggered a number of tsunamis in the historic past (Rodríguez-Vidal et al., 2011). These include the 1755 Lisbon tsunami (Baptista et al., 2003), the 1856 and 2003 tsunamis in Algeria (Roger and Hébert, 2008; Sahal et al., 2009) and the 1969 tsunami in the Atlantic (Guesmia et al., 1998). The earthquake-induced Lisbon tsunami appears in the geologic record from Portugal to the Gibraltar Strait (i.e., Dawson et al., 1991, 1995; Hindson et al., 1996; Dabrio et al., 1998, 2000; Hindson and Andrade, 1999; Luque et al., 1999, 2001, 2004; Luque, 2002; Whelan and Kelletat, 2005; Viana-Baptista et al., 2006; Gracia et al., 2006; Cuven et al., 2013) and even in southern England (Banerjee et al., 2001). The geologic record also shows evidence of ancient tsunamis impacting southwestern Spain, Portugal, Morocco (Galbis, 1932; Campos, 1991; Reicherter, 2001; Luque et al., 2001; Luque, 2002; Ruiz et al., 2004, 2005; Scheffers and Kelletat, 2005), and the Alboran Sea (IGN, 1991; Reicherter and Becker-Heidmann, 2009).

Few works have considered the deep-sea sedimentary implications of tsunamis that have impacted the Iberian margins. The 1522 Almeria earthquake $(M>6.5)$ affected a large area of the western Mediterranean, even though its epicentre occurred in the Gulf of Almeria along the Carboneras Fault Zone. The earthquake triggered submarine slides in the Gulf of Almeria and tsunami waves (Reicherter and BeckerHeidmann, 2009). The IODP Expedition 339 identified sandy deposits along the Gulf of Cádiz and west of the Portuguese slope (Fig. 16) as possible tsunami deposits (Stow et al., 2013b). Other tsunamirelated traction currents and deposits may occur along the Iberian slopes. While evidence of other events may exist in the study region, researchers have not established consistent sedimentological criteria for identifying paleo-tsunami deposits (Shanmugam, 2012b). Deeper water tsunami deposits and structures may resemble their shallow water counterparts, or might resemble turbidity and debris (or mud) flow sequences in terms of facies associations (Dawson and Stewart, 2007). 

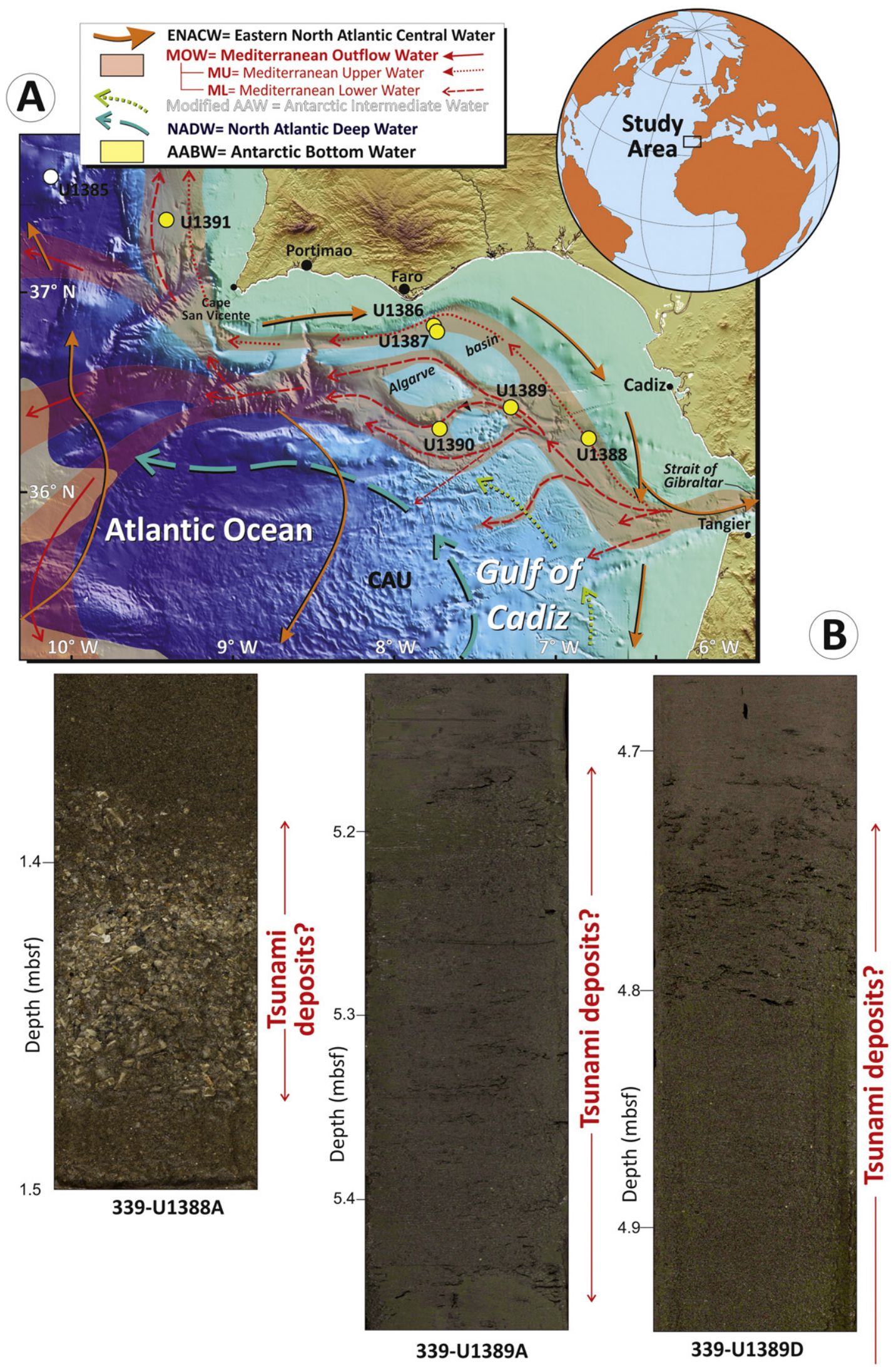

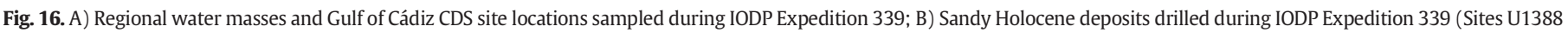
and U1389) interpreted as tsunami deposits (Stow et al., 2013b, Pers. Comm., Yasuhiro Takashimizu, Niigata University, Japan). 
Table 1

Summary of the oceanographic processes and products along the Iberian margins.

\begin{tabular}{|c|c|c|c|}
\hline Oceanographic processes & Main sedimentary processes & Main morphosedimentary products & Examples along the Iberian margins \\
\hline $\begin{array}{l}\text { Bottom currents \& } \\
\text { thermohaline circulation }\end{array}$ & $\begin{array}{l}\text { Erosion; sed. transport/reworked; } \\
\text { deposition }\end{array}$ & Large contourite deposits (drifts) \& erosional features & $\begin{array}{l}\text { NE Iberian margin; Alboran Sea; Gulf of } \\
\text { Cadiz; WIM; Galician margin; } \\
\text { Cantabrian Sea }\end{array}$ \\
\hline Overflows & $\begin{array}{l}\text { Erosion; sed. transport; depositional } \\
\text { (locally and distally) }\end{array}$ & $\begin{array}{l}\text { Contourite terraces; large channels, scours, furrows; } \\
\text { sandy-sheeted deposits, ripples, dunes \& sand/gravel } \\
\text { ribbons }\end{array}$ & Strait of Gibraltar; Theta Gap (?) \\
\hline $\begin{array}{l}\text { Processes at the interface } \\
\text { between water masses } \\
\text { (waves \& eddies) }\end{array}$ & $\begin{array}{l}\text { Erosion; sed. transport (re-suspension); } \\
\text { deposition }\end{array}$ & $\begin{array}{l}\text { Morphological changes along the slope gradient; large } \\
\text { contourite terraces, erosional abraded surfaces }\end{array}$ & $\begin{array}{l}\text { Alboran Sea, Gulf of Cádiz; Portuguese } \\
\text { Margin; Galician margin and Cantabrian } \\
\text { Sea }\end{array}$ \\
\hline Deep-water tidal currents & $\begin{array}{l}\text { On submarine canyons and adjacent areas, } \\
\text { contourite channels: reworked and } \\
\text { deposition }\end{array}$ & Bedforms (ripples \& dunes) & $\begin{array}{l}\text { Atlantic margins (especially at the } \\
\text { Extremadura and Ortegal Spurs and Gulf } \\
\text { of Cadiz) }\end{array}$ \\
\hline Deep-sea storms & Erosion; sed. transport (re-suspension) & Erosional \& depositional & $\begin{array}{l}\text { Ubiquitous (?).Atlantic \& Mediterranean } \\
\text { margins }\end{array}$ \\
\hline Eddies & Erosion; sed. transport (re-suspension) & Erosional \& depositional & $\begin{array}{l}\text { Gulf of Cadiz; West off Portugal; Galician } \\
\text { margin }\end{array}$ \\
\hline Secondary circulation & Erosion & Scours; furrows & $\begin{array}{l}\text { Ubiquitous. Atlantic \& Mediterranean } \\
\text { margins }\end{array}$ \\
\hline Dense shelf water cascades & $\begin{array}{l}\text { Sed. transport (density-driven flow, } \\
\text { re-suspension) }\end{array}$ & Erosional \& depositional & Mediterranean margins (Gulf of Lions) \\
\hline Internal waves \& solitons & $\begin{array}{l}\text { Erosional; sed. transport/reworked; } \\
\text { deposition }\end{array}$ & Erosional \& depositional Dunes; Sedimentary waves & $\begin{array}{l}\text { Ubiquitous. Internal waves along the } \\
\text { margins. Solitons associated to shelf } \\
\text { breaks }\end{array}$ \\
\hline $\begin{array}{l}\text { Other-related traction currents } \\
\text { (tsunamis, rogue- \& cyclone } \\
\text { waves) }\end{array}$ & $\begin{array}{l}\text { Sed. transport (mud flow, re-suspension); } \\
\text { slope instabilities }\end{array}$ & > Sed. Rates; Coarser sed. input & Southern Iberian margin, Alboran Sea \\
\hline
\end{tabular}

\section{Morphologic and sedimentary implications}

The descriptions above highlight a number of permanent and intermittent processes that affect bottom currents. These processes could be very variable as overflows, tides, eddies, deep-sea storms, secondary circulation, internal waves and tsunamis, rogue waves and cyclone waves. All these processes show some degree of variability and, although one of them can prevail in a particular situation, more probably there are several processes acting in combination to determine the bottom current's local direction and velocity. Many of these processes and their effects on deep-water sedimentation are not well understood. Along the Iberian margins, several of these processes interact locally or regionally with the seafloor to affect its morphology and sediment distribution (Table 1). We cannot however yet discern specific sequences of events or the relative influence of these processes from sedimentary evidence. Discussions and debate continue on how bottom currents form the range of morphologies observed among contourites. To stimulate this discussion, future analyses must include the wider and more complex range of deep-water processes described above. While local oceanographic setting provides first order constrains on contourite morphology, ancient contourite examples from the geologic record can also reveal how they may vary in response to different deep-marine conditions.

Specific bottom current facies have been described by many authors (see a recent compilation in Rebesco et al., 2014). The standard contourite facies model bi-gradational sequence was first proposed by Gonthier et al. (1984) and Faugères et al. (1984), based on the Faro Drift within the middle slope of the Gulf of Cádiz. This general model for contourites represents the transition from weaker to stronger bottom current flow, and then back to weaker conditions (Stow and Holbrook, 1984; Stow et al., 2002a; Huneke and Stow, 2008). The bigradational facies sequences are observed among ancient to recent contourite deposits, including the Brazilian margin (Viana and Faugères, 1998), the Irish margin (Øvrebø et al., 2006) and in ancient deposits (e.g., Chinese sedimentary basins, Gao et al., 1998). Authors commonly report partial or incomplete contourite sequences (Howe et al., 1994; Stoker et al., 1998; Shanmugam, 2000; Howe et al., 2002; Stow et al., 2002a, 2013a; Mulder et al., 2013). Further modifications of the contourite model (e.g., Stow et al., 2002a, 2002b; Stow, 2005; Stow and Faugères, 2008) have demonstrated a considerable degree of variation, thus complicating the establishment of a unique and systematic facies designation. Mulder et al. (2013) have recently demonstrated that a particular facies sequence may depend on the supply of coarser terrigenous clastic material provided by increased erosion of indurated mud along the flanks of confined contourite channels (mud clasts), by increased sediment supply from rivers (quartz grains) and/or by downslope mass transport along the continental shelf and upper slope. These results are consistent with the findings of Masson et al. (2010), that the classical contourite depositional sequence proposed by Gonthier et al. (1984) should be interpreted with special consideration given to the regional sedimentological background.

The Faro Drift deposits do not offer the best example of a contourite facies sequence due to the preponderance of mud within these deposits, and their location along the distal part of a much larger contourite depositional system (CDS). Other facies from different parts of the same depositional system do not fit neatly into the conceptual model suggested by the Faro Drift (e.g., Mulder et al., 2013; Stow et al., 2013a; Hernández-Molina et al., 2013, 2014). Mulder et al. (2013) have in fact showed that most of the contacts between the classical contourite facies (mottled, fine sand, coarse sand) are rather sharp than transitional, an observation that supports the interpretation by Shanmugam (2006, 2012a, 2013b). The proposed facies sequence for the Faro Drift could therefore serve as an appropriate model for fine-grained contourite deposits, for which pervasive bioturbation is a diagnostic feature. This interpretation, however, suggests that the Faro Drift does not offer a representative example of other types of contourite deposits (Martín-Chivelet et al., 2008; Shanmugam, 2012a, 2013b; Mulder et al., 2013). Other authors have described contourite settings with a higher proportion of sand (Shanmugam et al., 1993; Shanmugam, 2000, 2012a, 2013b), indicating that activity of bottom currents prevails over bioturbation.

This controversy in contourite identification demonstrates that contourites exhibit greater variation than the established facies model suggests and commonly include traction sedimentary structures. The contourite facies model thus would benefit from further modification. A consistent facies model however faces substantial challenges in 


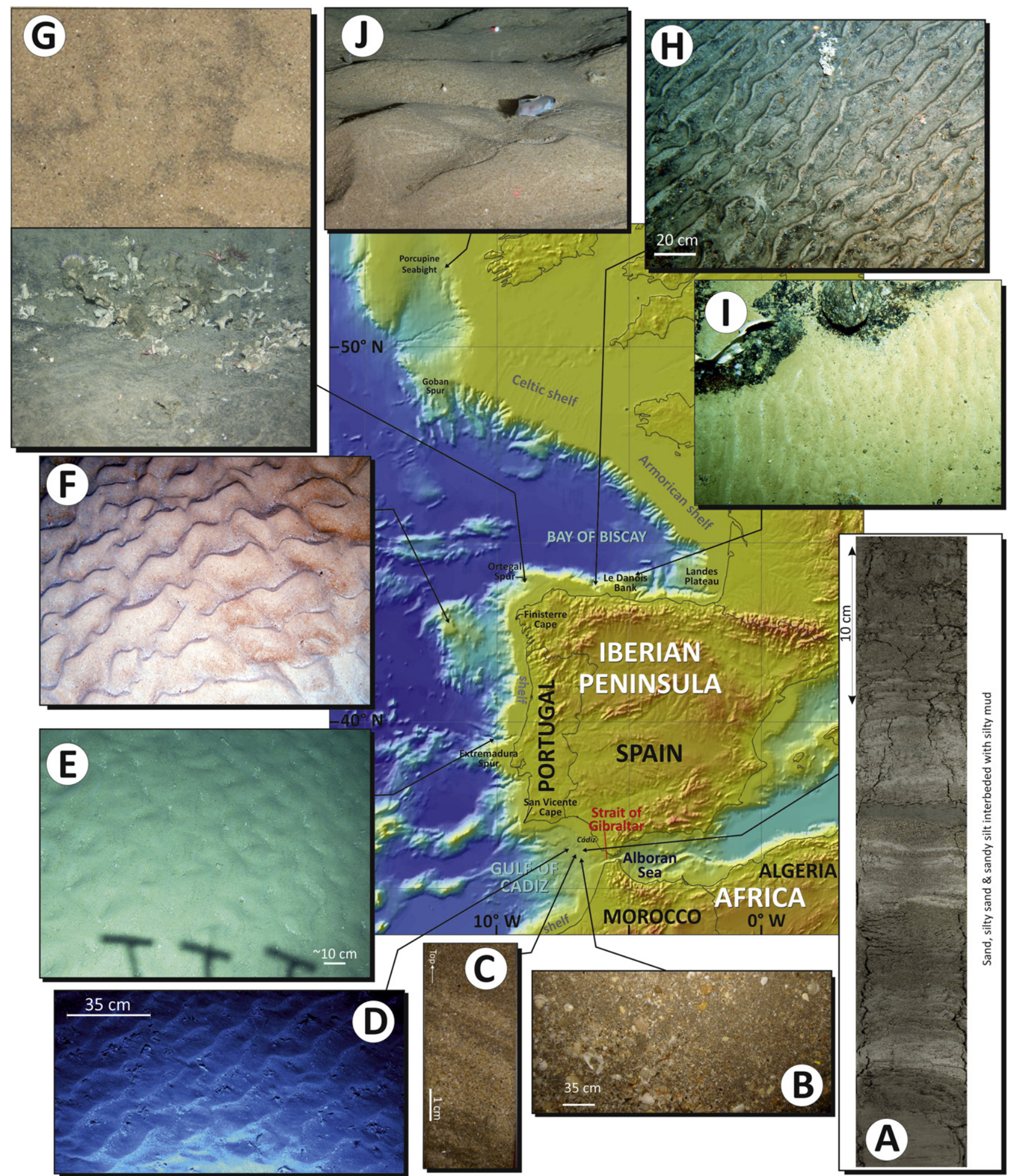

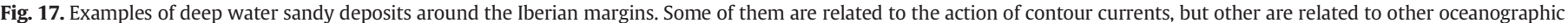

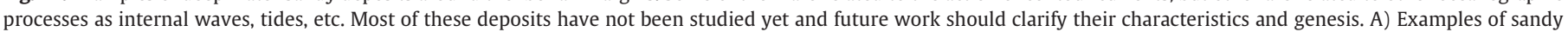

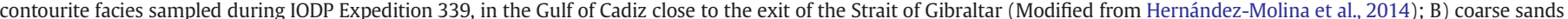

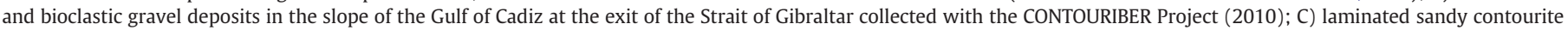

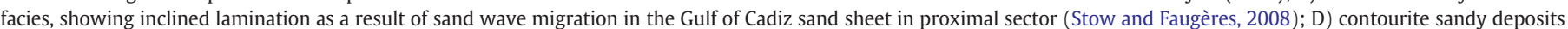

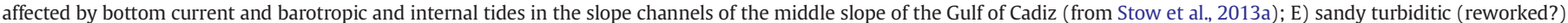

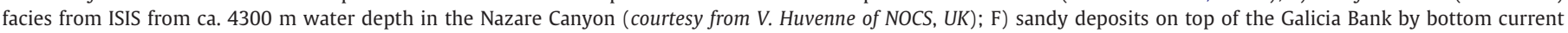

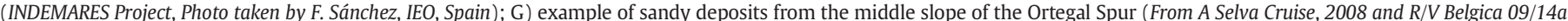

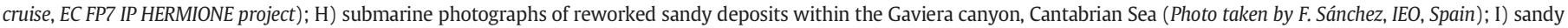

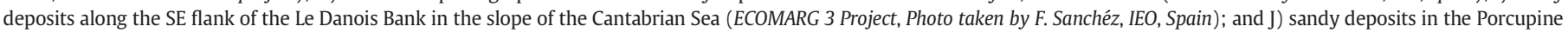
seabight, Irish continental slope (courtesy of MARUM, Germany). 


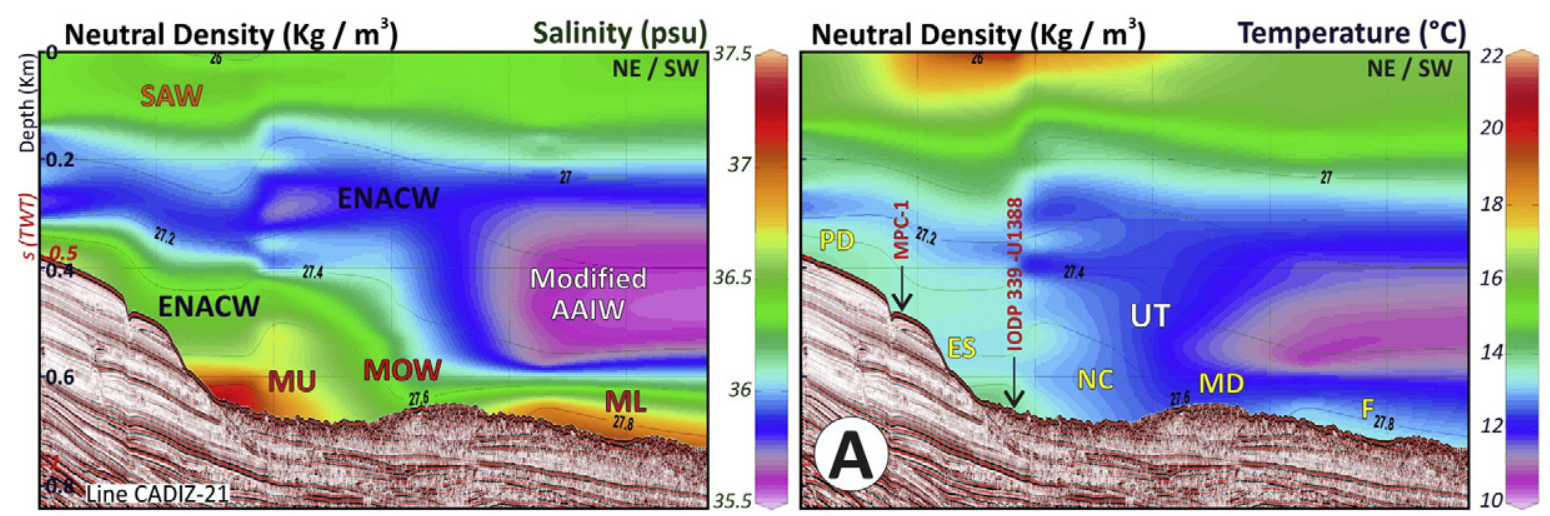

Northward Abs. Current Velocity (hourly mean) [ $\mathrm{m} / \mathrm{s}$ ] Eastward Abs. Current Velocity (hourly mean) [ $\mathrm{m} / \mathrm{s}$ ]
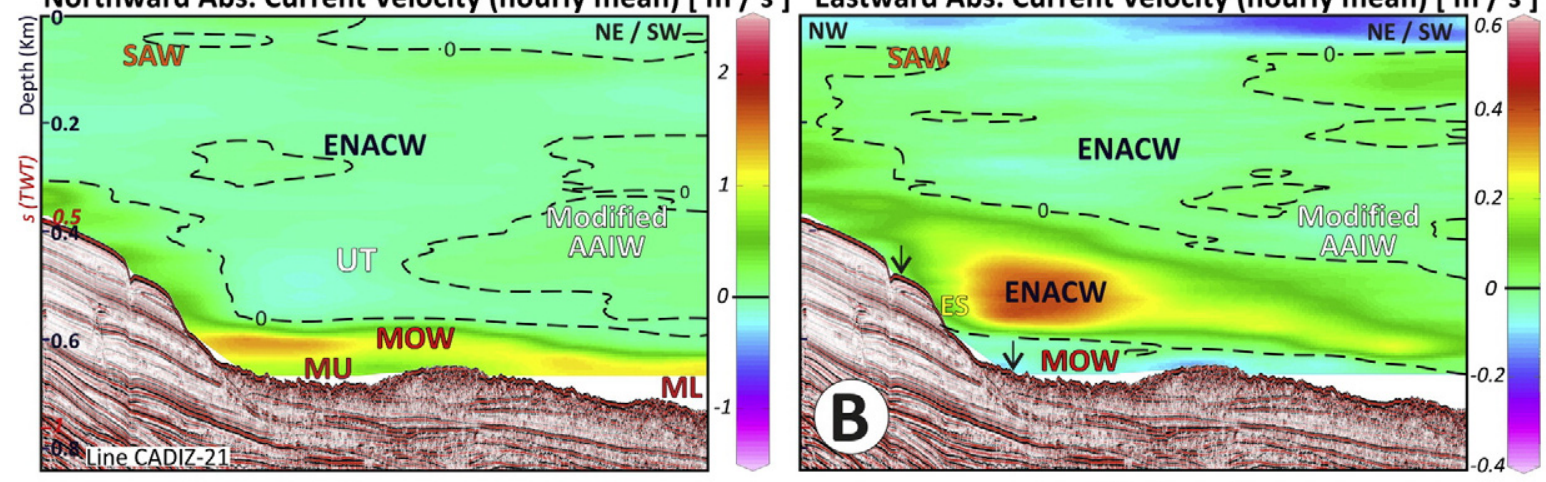

SAW = Superficial Atlantic Water

ENACW = Eastern North Atlantic Central Water

MOW $=$ Mediterranean Outflow Water

MU = Mediterranean upper core

$\mathbf{M L}=$ Mediterranean lower core

CT $=$ Contourite Terrace $-\left.\right|_{\text {UT }} ^{\text {UT Upper Terrace }}$

$\mathbb{N C}=$ Northern Channel

LTT $=$ Upper Terrace

ES = Erosional surface

$\beta=$ Furrows

$\mathbb{M D}=$ Mounded drift

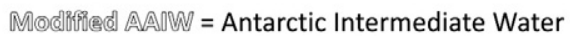

$P D=$ Plastered drift

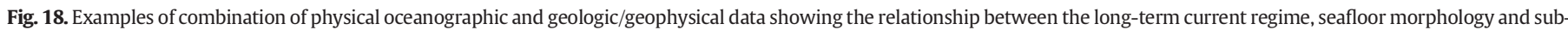

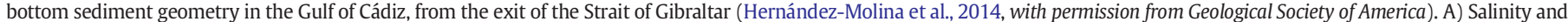

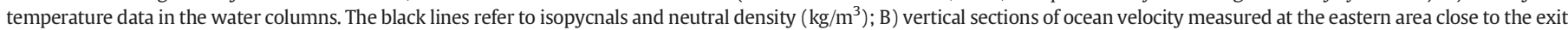

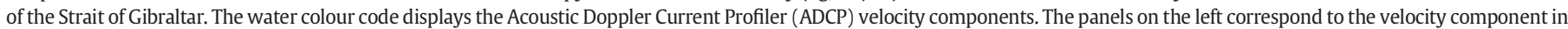

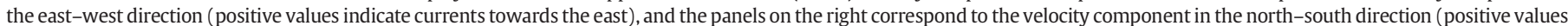
indicate current towards the north). The dashed black lines indicate where the current velocity is zero. See Fig. 2 for section locations.

terms of the wide range of oceanographic permanent and intermittent processes (and their spatial and temporal variation) that can influence development of CDS.

We began an effort to reassess of contourite facies during the IODP Expedition 339 along the Iberian margins, in the Gulf of Cádiz and off western Portugal (http://iodp.tamu.edu/scienceops/expeditions/ mediterranean_outflow.html), (Expedition 339 Scientists, 2012; Stow et al., 2013b; Hernández-Molina et al., 2013). The facies included sand-rich, muddy sand, silty-mud and mud-rich contourites, all of which formed at moderate $(20-30 \mathrm{~cm} / \mathrm{ky})$ to very high $(>100 \mathrm{~cm} / \mathrm{ky})$ rates of sedimentation. The contourites recovered during this expedition were remarkably uniform in composition and textural attributes. The muddy and silty contourite deposits displayed an absence of primary sedimentary structures, but exhibited intense continuous bioturbation throughout the section sampled. The cores also showed consistent, bi-gradational sequences with inverse and then normal grading as well as a number of partial sequence types. Expedition 339 also identified thick and extensive contourite sand deposits, as well as turbidite sands apparently reworked by bottom currents (Expedition 339 Scientists, 2012; Stow et al., 2013b; Hernández-Molina et al., 2013). These sands occurred in the proximal part of the CDS close to the Strait of Gibraltar (Fig. 17), where Expedition 339 retrieved a very thick and sandy contourite layer $(>10 \mathrm{~m})$ that showed traction sedimentary structures (Hernández-Molina et al., 2013, 2014; Brackenridge, 2014). Sand-rich contourites also occur in other areas around Iberia, such as the Galician and Cantabrian margins (Fig. 17) (Alejo et al., 2012). Future work around the Iberian margins will systematically categorize these sedimentary facies and frame them according to bottom current dynamics and other associated oceanographic processes (e.g., overflows, barotropic tidal currents) including intermittent processes (e.g., vertical eddies, deep sea storms, horizontal vortices, internal waves and tsunamis).

Sedimentologists have debated the differentiation between contourites and turbidites for almost five decades (Hollister, 1967; Piper, 1972; Hollister and Heezen, 1972; Bouma, 1972, 1973; Bouma and Hollister, 1973) but have not definitively established which structures distinguish contourites. Contourite processes can in fact trigger gravitational collapse that forms submarine lobes as in the Gulf of Cádiz (Habgood et al., 2003; Hanquiez et al., 2010) or rework previous turbiditic deposits (Shanmugam et al., 1993; Shanmugam, 2012a, 2013b). Contourite and turbiditic processes can also intermingle in both vertical and lateral dimensions, and thus form mixed deposits. Differentiating contourite from turbidite represents a major challenge for future research along the Iberian margins, especially given the legacy of emphasis on mass-transport and turbiditic processes in interpretations of Iberian margins deposits. 


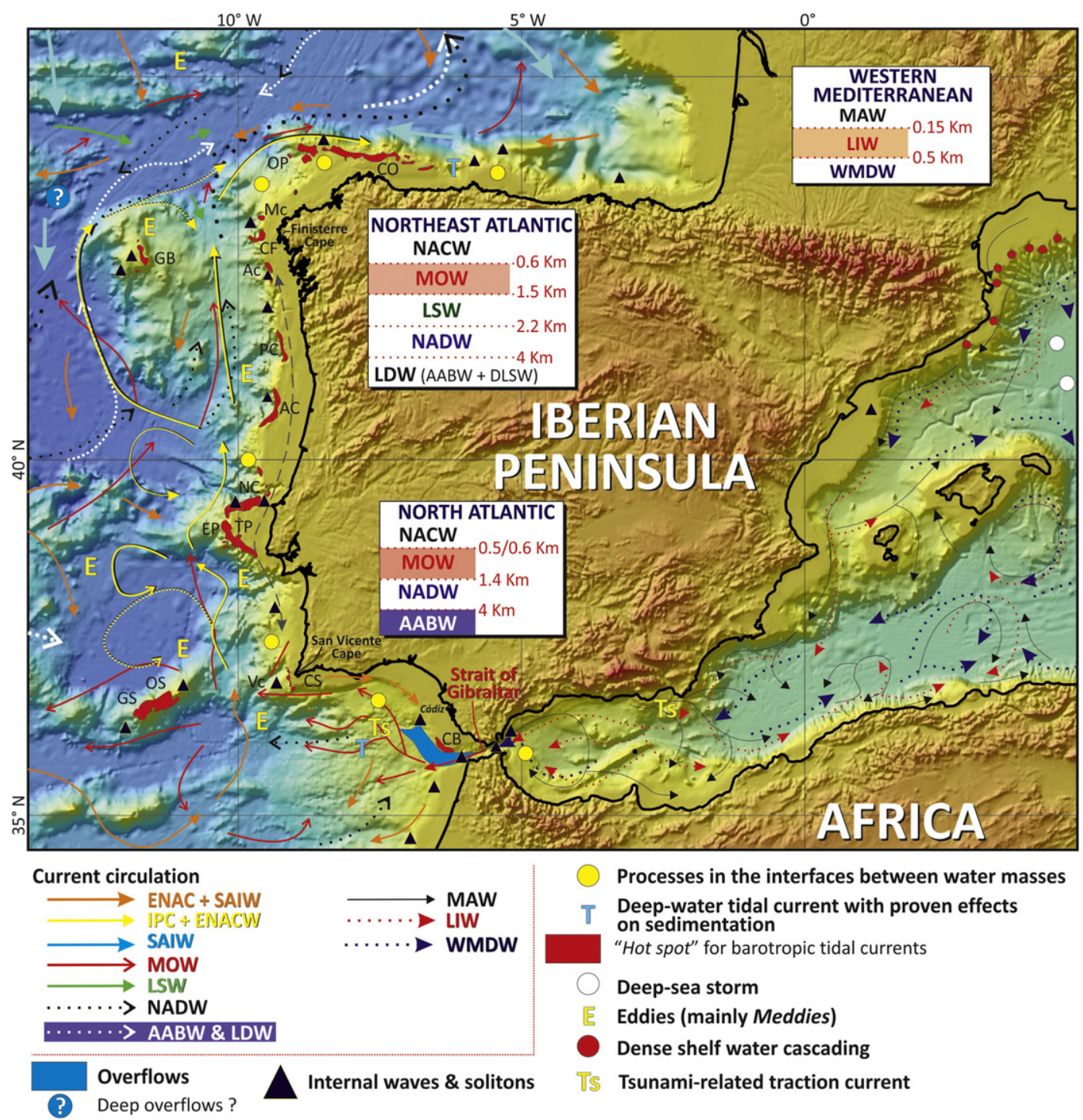

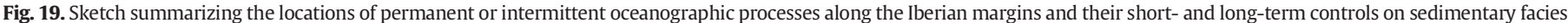

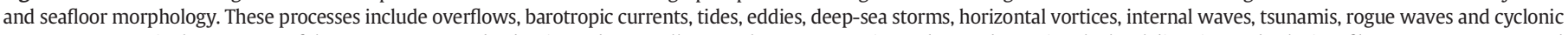

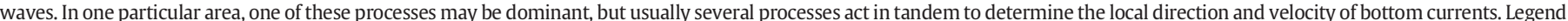

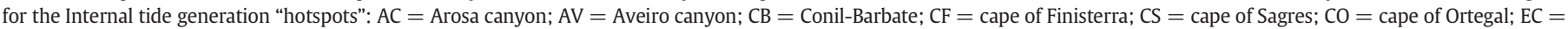

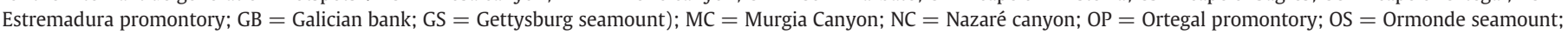

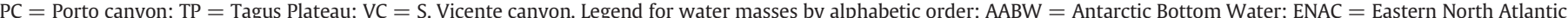

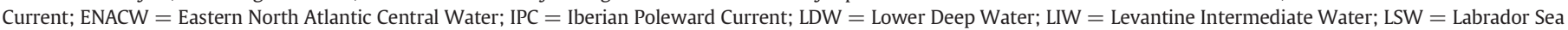

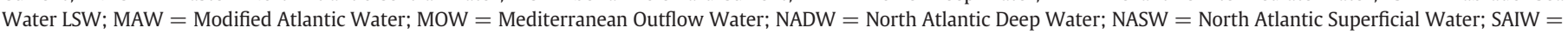
Subarctic Intermediate Water; WMDW = Western Mediterranean Deep Water.

Regional interpretations of the Iberian margins have generally underestimated the role of bottom currents in shaping the seafloor and controlling the sedimentary stacking pattern. Very large contourite drifts occur along these margins (see compilation at Llave et al., 2015a, 2015b) and small to intermediate sized drifts are ubiquitous (e.g., Ercilla et al., 2016). While CDS genetic models are under revision, bottom currents and associated oceanographic processes clearly control the physiography and sedimentation around the Iberian continental margins and adjacent basins. From all aforementioned oceanographic processes associated to bottom currents, the position of interfaces between major water masses and their vertical and spatial variation in time specifically appears to exert primary control in determining major morphologic changes (changes along the slope gradient), including the formation of the contourite terraces (Figs. 4, 5 and 18). Density contrasts that form boundaries (Hernandez-Molina et al., 2011; Ercilla et al., 2016; Llave et al., 2015a, 2015b) similar to those reported for other margins (e.g., Hernández-Molina et al., 2009; Preu et al., 2013) are important components of these interfaces due to their responses to internal waves, tidal waves, deep-sea storms, eddies, secondary circulations and other processes. A consistent CDS model thus requires monitoring of these processes and an accurate cause and effect description of how these processes affect deep-water sedimentation, sedimentary structures and CDS architecture.

\section{Final considerations}

\subsection{A new multidisciplinary approach}

Bottom current-controlled depositional, erosional and mixed morphological features commonly occur along the Iberian continental margins at different depths and in various settings. This paper depicts the bottom current circulation around the Iberian continental margins that are affected by a number of permanent and intermittent oceanographic processes (Fig. 19). Previous models for the margins have not 
fully acknowledged the role of these processes and they continue to elude our fullest understanding. Internal waves, tidal waves, deep-sea storms, eddies, secondary circulations and other deep-sea processes generally shape the seafloor over short- and/or long-term time scales. Future research should seek to interpret these oceanographic processes in sedimentary stacking patterns and the overall architecture of continental margin deposits.

A clearer understanding of oceanographic processes related to bottom currents and their associated sedimentary features requires a multidisciplinary approach, given the complexity of the phenomena under consideration. This approach should integrate frameworks of marine geology, physical oceanography and benthic biology. A combined analysis of sedimentology and fluid dynamics is a priority objective. The approach should specifically include next topics:

- Detailed studies of deep-water oceanographic processes related to flow phenomena, including internal waves, tides, benthic storms, eddies and vortices with the objective of understanding their importance, interactions and influence on bathymetric features.

- A more systematic understanding of the depositional, erosional and mixed morphological features, as well as their evolution over time and distribution at different points along the margin. Linking these features to specific oceanographic processes will help categorize small and large-scale features and clarify sedimentary facies associations.

- Studies about the general physiographic architecture of the margins and its relation with water masses structure and associated interphases require more attention.

- Numerical modelling can help link the variation in genetic processes to the range of observed erosional and depositional features.

- Detection and characterization of past pycnoclines based on proxies from the sedimentary record represents an important objective for future multidisciplinary research. Estimation of the depth range of water mass interfaces and the study of processes associated with these interfaces (such as baroclinic tides and internal waves) can inform the interpretation of contourite terraces along the Iberian continental slope. Paleoceanographic models can help determine potential periods of greater density contrasts within the pycnocline. Contourite terraces suggest relict features along the slope that hint at colder oceanic conditions in the past. These hypothetic conditions require further investigation due to their implications for regional and global climate dynamics.

- Research should also seek to detect and characterise intermediate and deep nepheloid layers. These layers often occur at water mass interfaces. Benthic boundary layers are also critical interfaces that determine seafloor morphology. These interfaces have mostly been studied from a biogeochemical perspective and have not been systematically integrated in the sedimentological and oceanographic models.

- We require a more comprehensive understanding of fluid dynamics around submarine obstacles.

- Oceanographic monitoring should also focus on linking erosional contourite morphological features to specific bottom current conditions (e.g., velocity, energy).

- Analysis of sedimentary evidence and ROV-assisted visual observations should relate modern erosional, depositional and mixed features to bottom current and associated processes. This analysis should query local outcrops on the seafloor, including channel flanks, slide scarps, etc., and synthesize observation with facies associations evident from cores (IODP, etc.) and other sedimentary evidence.

- A wide range of small-scale features (cores, outcrops and their lithologic facies), and large-scale features (depositional systems and seismic facies) require more specific linkages to oceanographic processes.

- Research should foster the analysis and evaluation of the influence of oceanographic processes on fragile geohabits, relict or active today, which could be situated in scenarios of risk because of deep environmental changes derived from water-mass circulation modifications.

- The current facies model must be adapted to include sandy facies. The facies model should also address interactions between bottom current and turbidite processes, and offer consistent interpretations of both sandy contourites and bottom-current reworked turbidite sands that occur along the Iberian margins.

The differing objectives, frameworks and terminology used in marine geology, physical oceanography and benthic biology make these integrative efforts a formidable task. Some of the challenges can be circumvented by deploying remote sensing technology (e.g., Automated Underwater Vehicles, e.g., AUVs and Remote Operated Vehicles, ROVs) and capitalizing on advances in data acquisition and processing to build a more complete picture of water column dynamics, seafloor morphology, contourite distribution and benthic community structure. Further development of seismic oceanographic techniques (Buffett et al., 2009; Carniel et al., 2012; Pinheiro et al., 2010) can help integrate in-situ observations with 2D (or 3D) images of the seafloor and water column (Fig. 18) while acoustic approaches integrated with oceanographic data such as CTD or (L) ADCP (Preu et al., 2011, 2013; Hernández-Molina et al., 2014) and instrumented moored stations (Rebesco et al., 2013). Highresolution, 3D seismic images (Campbell and Deptuck, 2012), multibeam and backscatter data (Palomino et al., 2011; Sweeney et al., 2012) will also help characterise contourite features and correlate them with specific oceanographic processes.

\subsection{Applied research}

Multidisciplinary approaches to understanding contourite development carry major implications for climate, resource exploration and basic science. Sandy contourites represent an entirely different deepwater sand deposit than turbidite sands. Given the prominent role of turbidite sands in deep-water oil and gas plays, understanding how their contourite counterparts form could fundamentally change deep water exploration paradigms (Viana, 2008; Stow et al., 2013b; Hernández-Molina et al., 2013). We will continue to explore the contourite processes and their implications for resource exploration, using IODP Expedition 339 data. These data show extensively distributed and well/moderated sorted sand deposits (Expedition 339 Scientists, 2012; Stow et al., 2013b; Hernández-Molina et al., 2013) that can potentially serve as reservoirs units, as well as muddy contourites that may function as hydrocarbon seals or source rocks and/or unconventional reservoirs (Viana, 2008; Shanmugam, 2012a, 2013a, 2013b; Brackenridge et al., 2013; Stow et al., 2013b). The frequent association of both sandy and muddy contourite deposits with cold-water coral mounds (Huvenne et al., 2009; Van Rooij et al., 2011; Somoza et al., 2014; Sánchez et al., 2014), which may function as unconventional reservoirs (Henriet et al., 2014) further demonstrate the potential for plays in these settings. As the climate warms due to the usage of these fossil fuels, we must also consider the role of deep-water circulation as a climate modulator. In addition to its effects on global circulation, variability in deep-water circulation also affects deep-water ecosystems, such as reefs. Growing interest in seafloor mining of metalliferous resources (Hoffert, 2008; Rona, 2008) will also benefit from better understanding of bottom current and associated processes dynamics. These types of deposits have been identified along the Iberian margins (e.g., González et al., 2009, 2010a, 2010b). Mapping of these deposits can help interpret their formation with respect to bottom currents and seafloor morphology parameters.

\section{Conclusions}

Based on this review work achieved by Geologists, Physical Oceanographers, Paleoceanographers and Benthic Biologists, we highlight 
that bottom current dynamics are commonly affected by a number of associated, permanent and intermittent, oceanographic processes, as overflows, tides, eddies, deep-sea storms, secondary circulation, internal waves and other-related traction currents (e.g., tsunamis). All these processes show some degree of variability and, although some of them can prevail in a particular situation, it is more probably to find several processes acting in combination determining the bottom current's local direction and velocity. Many of these processes and their effects on deep-water sedimentation are not understood. Along the Iberian margins, several of these processes interact locally or regionally with the seafloor affecting its morphology and sediment distribution, and three major conclusions could be considered:

a) Contourite depositional and erosional features are ubiquitous along the margins, indicating that bottom currents and associated oceanographic processes clearly control the physiography and sedimentation around the Iberian continental margins.

b) The position of interfaces between major water masses and their vertical and spatial variations in time specifically appears to exert primary control in determining major morphologic changes along the slope gradient, including the contourite terraces development. Density contrasts that form boundaries are important components of these interfaces due to their responses to internal waves, tidal waves, deep-sea storms, eddies, secondary circulations and other processes.

c) Contourite deposits exhibit greater variations than the established facies model for these deposits suggests. Therefore, a consistent facies model however faces substantial challenges in terms of the wide range of oceanographic permanent and intermittent processes that can influence in their development.

Future models thus require the monitoring of these oceanographic processes along the Iberian continental margins (as in another margin) and an accurate cause/effect description of them in terms of deep-water sedimentation, sedimentary structures and architecture. This approach should integrate frameworks of marine geology, physical oceanography and benthic biology.

Supplementary data to this article can be found online at http://dx. doi.org/10.1016/j.margeo.2015.12.008.

\section{Acknowledgements}

This contribution is a product of the IGCP-619 and INQUA-1204 projects, and is partially supported through the CTM 2008-06399-C04/MAR (CONTOURIBER); CTM 2012-39599-C03 (MOWER); CTM 2010-21229/ MAR projects and MARUM project GALIOMAR, as well as the Continental Margins Research Group (CMRG) at Royal Holloway University of London (UK). This work interpreted samples and data provided by the Integrated Ocean Drilling Program (IODP). The figures presented in this paper are original, partially adapted from previous works, and partially reproduced from previous works. Permission has been obtained for the reproduction or adaptation. We thank the British Oceanographic Data Center (BODC) and National Oceanographic Centre, Southampton (NOCS) for current metre data from Fig. 8, the EOLi (Earth Observation Link, European Space Agency) for some images included in Fig. 13; Yasuhiro Takashimizu (Niigata University, Japan) for permission to include an example of possible tsunami deposits in the Gulf of Cádiz in Fig. 16, V. Huvenne (NOCS, UK) for submarine photo of Fig. 17E. We are grateful to A. Piola (SHN, Argetina) and D. G. Borisov (Russian Academy of Sciences, Russia) for their helpful guidance in revising the manuscript before it submission. We also thank the guest editors, D. Van Rooij and A. Rüggeberg (Ghent Univ. Belgium); C. Gong (Univ. Texas at Austin, USA) and E. Martorelli (Roma Univ.) for their input and very positive and helpful feedback and discussions that have improved the presentation of this research.

\section{References}

Abrantes, F., Alt-Epping, U., Lebreiro, S., Voelker, A., Schneider, R., 2008. Sedimentological record of tsunamis on shallow-shelf areas: the case of the 1969 AD and 1755 AD tsunamis on the Portuguese shelf off Lisbon. Mar. Geol. 249, 283-293.

van Aken, H.M., 2000. The hydrography of the mid-latitude Northeast Atlantic Ocean, II. The intermediate water masses. Deep-Sea Res. I 47 (5), 789-824.

Albérola, C., Rousseau, S., Millot, C., Astraldi, M., Font, J., Garcia-Lafuente, J., Gasparini, G.P., Send, U., Annick, V.A., 1995. Tidal currents in the western Mediterranean Sea. Oceanol. Acta 18 (2), 273-284.

Alejo, I., Nombela, M.A., Ercilla, G., Brackenridge, R.E., Francés, G., Pérez-Arlucea, M., Mena, A., Hernández-Molina, F.J., Stow, D.A.V., Medialdea, T., 2012. Caracterización de los sedimentos superficiales en tres sistemas deposicionales contorníticos (Golfo de Cádiz, Cabo Ortegal y El Cachucho): implicaciones conceptuales. Geo-Temas 13, 1-4.

Allen, S.E., Durrieu de Madron, X., 2009. A review of the role of submarine canyons in deep-ocean exchange with the shelf. Ocean Sci. 5, 607-620.

Alvarez Fanjul, E., Pérez, B., Rodríguez, I., 1997. A description of the tides in the Eastern North Atlantic. Prog. Oceanogr. 40, 217-244.

Ambar, I., Serra, N., Brogueira, M.J., Cabeçadas, G., Abrantes, F., Freitas, P., Gonçalves, C., Gonzalez, N., 2002. Physical, chemical and sedimentological aspects of the Mediterranean outflow off Iberia. Deep-Sea Res. II 49, 4163-4177.

Ambar, I., Serra, N., Neves, F., Ferraira, T., 2008. Observations of the Mediterranean undercurrent and eddies in the Gulf of Cádiz during 2001. J. Mar. Syst. 71 (1-2), 195-220.

Apel, J.R., 2000. Solitons near Gibraltar: views from the European remote sensing satellites. Report GOA 2000-1. Global Ocean Association, Silver Spring, MD.

Apel, J.R., 2004. Oceanic internal waves and solitons. In: Jackson, C.R., Apel, J.R. (Eds.), Synthetic Aperture Radar Marine User's Manual. Silver Spring, US Department of Commerce, National Oceanic and Atmospheric Administration (189-206 pp.).

Apel, J.R., Ostrovsky, L.A., Stepanyants, Y.A. 1995. Internal solitons in the ocean. Report MERCJRA0695. Milton S. Eisenhower Research Center, APL, The John Hopkins University, US (69 pp.).

Arhan, M., Carton, X., Piola, A., Zenk, W., 2002. Deep lenses of circumpolar water in the Argentine Basin. J. Geophys. Res. 107 (C1), 3007.

Arhan, M., Mercier, H., Park, Y.-H., 2003. On the deep water circulation of the Eastern South Atlantic Ocean. Deep-Sea Res. I Oceanogr. Res. Pap. 50, 880-916.

Armi, L., Farmer, D.M., 1988. The flow of Mediterranean water through the strait of Gibraltar. Prog. Oceanogr. 21, 1-105.

Armi, L., Zenk, W., 1984. Large lenses of highly saline Mediterranean water. J. Phys. Oceanogr. 14, 1560-1576.

Arzola, R.G., Wynn, R.B., Lastras, G., Masson, D.G., Weaver, P.P.E., 2008. Sedimentary features and processes in the Nazaré and Setúbal submarine canyons, west Iberian margin. Mar. Geol. 250, 64-88.

Azevedo, A., da Silva, J.C.B., New, A.L., 2006. On the generation and propagation of internal solitary waves in the southern Bay of Biscay. Deep-Sea Res. I 53, 927-941.

Bache, F., Popescu, S.-M., Rabineau, M., Gorini, C., Suc, J.-P., Clauzon, G., Olivet, J.-L., Rubino, J.-L., Melinte-Dobrinescu, M.C., Estrada, F., Londeix, L., Armijo, R., Meyer, B., Jolivet, L., Jouannic, G., Leroux, E., Aslanian, D., Dos Reis, A.T., Mocochain, L., Dumurdžanov, N., Zagorchev, I., Lesić, V., Tomić, D., Çağatay, M.N., Brun, J.-P., Sokoutis, D., Csato, I., Ucarkus, G., Çakir, Z., 2012. A two-step process for the reflooding of the Mediterranean after the Messinian salinity crisis. Basin Res. 24, 125-153.

Baines, P.G., 1982. On internal tide generation models. Deep-Sea Res. 29 (3A), 307-338.

Banerjee, D., Murray, A.S., Foster, J.L.D., 2001. Scilly islands UK: optical dating of a possible tsunami deposit drom the 1755 Lisbon earthquake. Quat. Sci. Rev. 20 (5-9), 715-718.

Baptista, M.A., Miranda, J.M., Chierici, F., Zitellini, N., 2003. New study of the 1755 earthquake source based on multi-channel seismic survey data and tsunami modeling. Nat. Hazards Earth Syst. Sci. 3, 333-340.

Baringer, M.O., Price, J.F., 1997. Mixing and spreading of the Mediterranean outflow. J. Phys. Oceanogr. 27, 1654-1677.

Baringer, M.O., Price, J.F., 1999. A review of the physical oceanography of the Mediterranean outflow. Mar. Geol. 155 (1-2), 63-82.

Battisti, D.S., Clarke, A.J., 1982. A simple method for estimating barotropic tidal currents on continental margins with specific applications to the M2 tide off the Atlantic and Pacific coasts of the United States. J. Phys. Oceanogr. 12, 8-16.

Bearmon, G., 1989. Ocean Chemistry and Deep-sea Sediments. The Open University, Pergamon (134 pp.).

Borenäs, K., Wåhlin, A., 2000. Limitations of the streamtube model. Deep-Sea Res. 47, $1333-1350$.

Borenas, K., Wahlin, A., Ambar, I., Serra, N., 2002. The Mediterranean outflow splitting - a comparison between theoretical models and CANIGO data. Deep-Sea Res. II 49, 4195-4205.

Bouma, A.H., 1972. Recent and ancient turbidites and contourites. Trans. Gulf Coast Assoc. Geol. Soc. 22, 205-221.

Bouma, A.H., 1973. Contourites in Niessenflysch, Switzerland. Eclogae Geol. Helv. 66, 315-323.

Bouma, A.H., Hollister, C.D., 1973. Deep ocean basin sedimentation. In: Middleton, G.V., Bouma, A.H. (Eds.), Turbidites and Deep-Water Sedimentation. SEPM Pacific section Short Course, SEPM, Anaheim, CA, pp. 79-118.

Bower, A.S., Armi, L., Ambar, I., 1997. Lagrangian observations of meddy formation during a Mediterranean undercurrent seeding experiment. J. Phys. Oceanogr. 27, 2545-2575.

Bower, A.S., Fratantoni, D.M., Johns, W.E., Peters, H., 2002. Gulf of Aden eddies and their impact on Red Sea Water. Geophys. Res. Lett. 29, 1-21.

Brackenridge, R.A., 2014. Contourites in the Gulf of Cadiz: characterisation, controls and wider implications for hydrocarbon exploration. PhD thesis, Heriot-Watt University, Unpublished. 
Brackenridge, R.A., Hernández-Molina, F.J., Stow, D.A.V., Llave, E., 2013. A Pliocene mixed contourite-turbidite system offshore the Algarve Margin, Gulf of Cádiz: seismic response, margin evolution and reservoir implications. Mar. Pet. Geol. 46, 36-50.

Brandt, P., Alpers, W., Backhaus, J.O., 1996. Study of the generation and propagation of internal waves in the Strait of Gibraltar using a numerical model and synthetic aperture radar images of the European ERS 1 satellite. J. Geophys. Res. 101, 14237-14252.

Brandt, P., Rubina, A., Alpers, W., Backhaus, J.O., 1997. Internal waves in the strait of Messina studied by a numerical model and synthetic aperture radar images from the ERS $1 / 2$ satellites. J. Phys. Oceanogr. 27, 648-663.

Bruno, M., Vázquez, A., Gómez-Enri, J., Vargas, J.M., García-Lafuente, J.M., Ruiz-Cañavate, A., Mariscal, L., Vidal, J.M., 2006. Observations of internal waves and associated mixing phenomena in the Portimao Canyon area. Deep-Sea Res. II 53 (11-13), 1219-1240.

Bryden, H.L., Candela, J., Kinder, T.H., 1994. Exchange through the Strait of Gibraltar. Prog. Oceanogr. 33, 201-248.

Buffett, G.G., Biescas, B., Pelegrí, J.L., Machín, F., Sallar, V., Carbonell, R., Klaeschen, D. Hobbs, R., 2009. Seismic reflection along the path of the Mediterranean undercurrent. Cont. Shelf Res. 29, 1848-1860.

Cacchione, D.A., Pratson, L.F., Ogston, A.S., 2002. The shaping of continental slopes by internal tides. Science 296 (5568), 724-727.

Campbell, D.C., Deptuck, M.E., 2012. Alternating bottom-current-dominated and gravityflow-dominated deposition in a lower slope and rise setting-insights from the seismic geomorphology of the Western Scotian Margin, Eastern Canada. In: Prather, B.E. Deptuck, M.E., Mohrig, D., Van Hoorn, B., Wynn, R.B. (Eds.), Application of the Principles of Seismic Geomorphology to Continental-Slope and Base-of-Slope Systems: Case Studies from Seafloor and Near-Seafloor Analogues. Society for Sedimentary Geology, Tulsa, Special Publication 99, pp. 329-346.

Campos, M.L., 1991. Tsunami hazard on the Spanish coasts of the Iberian Peninsula. Sci. Tsunami Haz. 9, 83-90.

Canals, M., Danovaro, R., Heussner, S., Lykousis, V., Puig, P., Trincardi, F., Calafat, A.M., Durrieu de Madron, X., Palanques, A., Sanchez-Vidal, A., 2009. Cascades in Mediterranean submarine grand canyons. Oceanography 22, 26-43.

Canals, M., Puig, P., Durrieu de Madron, X., Heussner, S., Palanques, A., Fabrés, J., 2006. Flushing submarine canyons. Nature 444 (7117), 354-357.

Candela, J., 2001. Mediterranean water and global circulation. In: Siedler, G., Church, J., Gould, J. (Eds.), Ocean Circulation and Climate. Academic Press, San Diego, Ca, pp. 419-429.

Carniel, S., Bergamasco, A., Book, J.W., Hobbs, R.W., Sclavo, M., Wood, W.T., 2012. Tracking bottom waters in the Southern Adriatic Sea applying seismic oceanography techniques. Cont. Shelf Res. 44, 30-38.

Carton, X., Cherubin, L., Paillet, J., Morel, Y., Serpette, A., Le Cann, B., 2002. Meddy coupling with a deep cyclone in the gulf of Cádiz. J. Mar. Syst. 32, 13-42.

Cartwright, D.E., Edden, A.C., Spencer, R., Vassie, J.M., 1980. The tides of the northeast Atlantic ocean. Philos. Trans. R. Soc. Lond. A 298 (1436), 87-139. http://dx.doi.org/10. 1098/rsta.1980.0241.

Cheney, R.E., Marsh, J.G., Beckley, B.D., 1983. Global mesoscale variability from collinear tracks of seasat altimeter data. J. Geophys. Res. 88, 4343-4354

Cherubin, L., Carton, X., Paillet, J., Morel, Y., Serpette, A., 2000. Instability of the Mediterranean water undercurrents southwest of Portugal: effects of baroclinicity and of topography. Oceanol. Acta 23 (5), 551-573.

Correia, S.M.L., 2003. Observation of Internal Waves Using Multisensory Satellite Data off the Iberian Peninsula ( $\mathrm{PhD}$ thesis) University of Lisbon, Institute of Oceanography.

Cossu, R., Wells, M., 2013. The evolution of submarine channels under the influence of Coriolis forces: experimental observations of flow structures. Terra Nova 25, 65-71. http://dx.doi.org/10.1111/ter.12006.

Cossu, R., Wells, M., Wåhlin, A., 2010. Influence of the Coriolis force on the flow structure of turbidity currents in submarine channel systems. J. Geophys. Res. Oceans 115 (11), C11016.

Cuven, S., Paris, R., Falvard, S., Miot-Noirault, E., Benbakkar, M., Schneider, J.-L., Billy, I. 2013. High-resolution analysis of a tsunami deposit: case-study from the 1755 Lisbon tsunami in southwestern Spain. Mar. Geol. 337, 98-111.

Dabrio, C.J., Zazo, C., Goy, J.L., Sierro, F.J., Borja, F., Lario, J., Gonzáles, J.A., Flores, J.A., 2000. Depositional history of estuarine infill during the last postglacial transgression (Gulf of Cádiz, Southern Spain). Mar. Geol. 162 (2-4), 381-404.

Dabrio, C.J., Zazo, C., Lario, J., Goy, J.L., Sierro, F.J., Borja, F., González, J.A., Flores, J.A., 1998. Holocene incised-valley fills and coastal evolution in the Gulf of Cádiz (southern Spain). Mediterr. Black Sea Subcommission Newsl. 20, 45-48.

Davies, T.A., Laughton, A.S., 1972. Sedimentary processes in the North Atlantic. In: Laughton, A.S., Berggren, W.A. (Eds.), Initial Reports of Deep Sea Drilling Project 12 U.S. Government Printing Office, Washington D.C., pp. 905-934.

Dawson, A.G., Stewart, I., 2007. Tsunami deposits in the geological record. Sediment. Geol. 200, 166-183.

Dawson, A.G., Foster, I.D., Shi, S., Smith, D.E., Long, D., 1991. The identification of tsunami deposits in coastal sediment sequences. Sci. Tsunami Haz. 9, 73-82.

Dawson, A.G., Hindson, R., Andrade, C., Freitas, C., Parish, R., Bateman, M., 1995. Tsunami sedimentation associated with the Lisbon earthquake of 1 November AD 1755: Boca do Rio, Algarve, Portugal. The Holocene 5, 209-215.

Dewar, W.K., Meng, H., 1995. The propagation of submesoscale coherent vortices. J. Phys. Oceanogr. 25, 1745-1770.

Dickson, R., McCave, I.N., 1986. Nepheloid layers on the continental slope west of Porcupine Bank. Deep Sea Res. Part A 33, 791-818.

Dickson, R.B., Gould, W.J., Muller, T.J., Maillard, C., 1985. Estimates of the mean circulation in the deep ( $>2000 \mathrm{~m}$ ) layer of the eastern North Atlantic. Prog. Oceanogr. 14, 103-127.

Duggen, S., Hoernle, K., Van den Bogaard, P., Rüpke, L., Morgan, J.P., 2003. Deep roots of the Messiniam salinity crisis. Nature 422, 602-606.

Durrieu de Madron, X., Houpert, L., Puig, P., Sanchez-Vidal, A., Testor, P., Bosse, A., Estournel, C., Somot, S., Bourrin, F., Bouin, M.N., Beauverger, M., Beguery, L., Calafat, A., Canals, M.,
Cassous, C., Coppola, L., Dausse, D., D'Ortenzio, F., Font, J., Heussner, S., Kunesch, S. Lefevre, D., Le Goff, H., Martín, J., Mortier, L., Palanques, A., Raimbault, P., 2013. Interaction of dense shelf water cascading and open-sea convection in the Northwestern Mediterranean during winter 2012. Geophys. Res. Lett. 40, 1379-1385.

Durrieu de Madron, X., Zervakis, V., Theocharis, A., Georgopoulos, D., 2005. Comments on "Cascades of dense water around the world ocean". Prog. Oceanogr. 64, 83-90.

Dykstra, M., 2012. Deep-water tidal sedimentology. In: Davis Jr., R.A., Dalrymple, R.W. (Eds.), Principles of Tidal Sedimentology, pp. 371-395 http://dx.doi.org/10.1007/ 978-94-007-0123-6_14.

Einsele, G., 2000. Sedimentary Basins. Evolution, Facies, and Sediment Budget. second ed. Springer-Verlag, Berlin (792 pp.)

Emery, K.O., 1956. Deep standing waves in California basins. Limnol. Oceanogr. 1, 35-41.

Ercilla, G., Baraza, J., Alonso, B., Estrada, F., Casas, D., Farrán, M., 2002. The Ceuta drift, Alboran sea (Southwestern Mediterranean). In: Stow, D.A.V., Pudsey, C.J., Howe, J.A., Faugères, J.-C., Viana, A.R. (Eds.), Deep-Water Contourite Systems: Modern Drifts and Ancient Series, Seismic and Sedimentary Characteristics. Geological Society, London, Memoir 22, pp. 155-170.

Ercilla, G., Juan, C., Hernández-Molina, F.J., Bruno, M., Estrada, F., Alonso, B., Casas, D., Farran, M., Llave, E., García, M., Vázquez, J.T., D'Acremont, E., Gorini, C., Palomino, D., Valencia, El Moumni, B., Ammar, A., 2016. Significance of bottom currents in deepsea morphodynamics: An example from the Alboran Sea. Mar. Geol. 378, 157-170.

Expedition 339 Scientists, 2012. Mediterranean Outflow: Environmental Significance of the Mediterranean Outflow Water and its Global Implications. IODP Prelim. Rep. 339. http://dx.doi.org/10.2204/ iodp.pr.339.2012.

Farmer, D.M., Armi, L., 1988. The flow of Atlantic water through the Strait of Gibraltar. Prog. Oceanogr. 21, 1-105.

Farmer, D.M., Armi, L., 1999. The generation and trapping of internal solitary waves over topography. Science 283, 188-190.

Faugères, J.-C., Mulder, T., 2011. Contour currents and contourite drifts. In: Hüneke, H. Mulder, T. (Eds.), Deep-sea Sediments. Elsevier, Amsterdam, Developments in Sedimentology 63, pp. 149-214.

Faugères, J.-C., Gonthier, E., Stow, D.A.V., 1984. Contourite drift molded by deep Mediterranean outflow. Geology 12, 296-300.

Faugères, J.-C., Mezerais, M.L., Stow, D.A.V., 1993. Contourite drift types and their distribution in the North and South Atlantic Ocean basins. Sediment. Geol. 82, 189-203.

Faugères, J.-C., Stow, D.A.V., Imbert, P., Viana, A.R., 1999. Seismic features diagnostic of contourite drifts. Mar. Geol. 162, 1-38.

Flood, R.D., Shor, A.N., 1988. Mudwaves in the Argentine Basin and their relationship to regional bottom circulation patterns. Deep-Sea Res. 35, 943-972.

Fohrmann, H., Backhaus, J.O., Blaume, F., Rumohr, J., 1998. Sediments in bottom-arrested gravity plumes: numerical case studies. J. Phys. Oceanogr. 28, 2250-2274.

Font, J., Puig, P., Salat, J., Palanques, A., Emelianov, M., 2007. Sequence of hydrographic changes in the NW Mediterranean deep water due to the exceptional winter 2005. Sci. Mar. 71, 339-346.

Galbis, R.J., 1932. Catálogo Sísmico de la Zona Comprendida Entre los Meridianos 58 E y 208 W de Greenwich y los Paralelos 458 y 258 N. Dirección General del Instituto Geográfico, Catastral y de Estadística, Madrid.

Gao, Z.Z., Eriksson, K.A., He, Y.B., Luo, S.S., Guo, J.H., 1998. Deep-Water Traction Current Deposits - A Study of Internal Tides, Internal Waves, Contour Currents and Their Deposits. Science Press, Beijing, New York (128 pp.)

García, G., Lobo, P., Maldonado, A., Hernández-Molina, F.J., Bohoyo, F., Pérez, L.F., 2016a. Highresolution seismic stratigraphy and morphology of the Scan Basin contourite fan, southern Scotia Sea, Antarctica. Mar. Geol. 378, 361-373.

Garcia Lafuente, J.M., Cano Lucana, N., 1994. Tidal dynamics and associated features of the northwestern shelf of the Alboran sea. Cont. Shelf Res. 14 (1), 1-21.

García, M., Hernández-Molina, F.J., Alonso, B., Vázquez, J.T., Ercilla, G., Llave, E., Casas, D., 2015b. Sub-circular depression structures and other erosive features at the Guadalquivir Bank Margin uplift, Gulf of Cadiz: interaction between bottom current, masswasting and tectonic processes. Mar. Geol. (in press).

García, M., Hernández-Molina, F.J., Llave, E., Stow, D.A.V., León, R., Fernández-Puga, M.C. Díaz del Río, V., Somoza, L., 2009. Contourite erosive features caused by the Mediterranean outflow water in the Gulf of Cádiz: quaternary tectonic and oceanographic implications. Mar. Geol. 257, 24-40.

García-Lafuente, J., Delgado, J., Sánchez-Román, A., Soto, J., Carracedo, L., Díaz del Río, G. 2009. Interannual variability of the Mediterranean outflow observed in Espartel sill, western Strait of Gibraltar. J. Geophys. Res. 114, C10018.

Gardner, W.D., Sullivan, L.G., 1981. Benthic storms: temporal variability in a deep ocean nepheloid layer. Science 213, 229-331.

Garrett, C., 2001. What is the "near-inertial" band and why is it different from the rest of the internal wave spectrum? J. Phys. Oceanogr. 31, 962-971.

Garrett, C., 2003. Internal tides and ocean mixing. Science 301, 1858-1859.

Gasser, M., Pelegrí, J.L., Nash, D., Peters, H., García-Lafuente, J., 2011. Topographic control on the nascent Mediterranean outflow. Geo-Mar. Lett. 31, 301-314. http://dx.doi.org/ 10.1007/s00367-011-0255-X.

Gaudin, M., Berné, S., Jouanneau, J.-M., Palanques, A., Puig, P., Mulder, T., Cirac, P., Rabineau, M., Imbert, P., 2006. Massive sand beds attributed to deposition by dense water cascades in the Bourcart canyon head, Gulf of Lions (northwestern Mediterranean Sea). Mar. Geol. 234, 111-128.

Gill, A.E., 1982. Atmosphere-Ocean Dynamics. Academic Press (662 pp.)

Gómez-Ballesteros, M., Druet, M., Muñoz, A., Arrese, B., Rivera, J., Sánchez, F., Cristobo, J., Parra, S., García-Alegre, A., González-Pola, C., Gallastegui, J., Acosta, J., 2014. Geomorphology of the Avilés Canyon System, Cantabrian Sea (Bay of Biscay). Deep-Sea Res. Il 106, 99-117.

Gong, C., Wang, Y., Zhu, W., Li, W., Xu, Q., 2013. Upper Miocene to quaternary unidirectionally migrating deep-water channels in the Pearl River mouth basin, northern south China sea. AAPG Bull. 97, 285-308. 
Gong, C., Wang, Y., Xu, S., Pickering, K.T., Peng, X., Li, W., Y.Q., 2015. The northeastern South China Sea margin created by the combined action of down-slope and along-slope processes: processes, products and implications for exploration and paleoceanography. Mar. Pet. Geol. 64, 233-249.

Gonthier, E., Faugères, J.-C., Stow, D.A.V., 1984. Contourite facies of the Faro Drift, Gulf of Cádiz. In: Stow, D.A.V., Piper, D.J.W. (Eds.), Fine Grained Sediments, Deep-Water Processes and Facies. Geological Society, London, Special Publication 15, pp. 275-291.

González, F.J., Somoza, L., León, R., Medialdea, T., 2010b. Ferromanganese deposits associated to the Cádiz contourite channel: imprints of the Mediterranean outflow water. Geo-Temas 11, 55-56.

González, F.J., Somoza, L., Lunar, R., Martínez-Frías, J., Martín Rubí, J.A., Torres, T., Ortiz, J.E Díaz del Río, V., 2010a. Internal features, mineralogy and geochemistry of Fe-Mn nodules from the Gulf of Cádiz: the role of the Mediterranean outflow water undercurrent J. Mar. Syst. 80 (3/4), 203-218. http://dx.doi.org/10.1016/j.jmarsys.2009.10.010.

González, F.J., Somoza, L., Lunar, R., Martínez-Frías, J., Martín Rubí, J.A., Torres, T., Ortiz, J.E., Díaz del Río, V., Pinheiro, L., Magalhaes, V.H., 2009. Hydrocarbon-derived ferromanganese nodules in carbonate-mud mounds from the Gulf of Cádiz: mud-breccia sediments and clasts as nucleation sites. Mar. Geol. 261 (1/4), 64-81.

Gonzalez-Pola, C., Diaz del Rio, G., Ruiz-Villarreal, M., Sanchez, R.F., Mohn, C., 2012. Circulation patterns at Le Danois Bank, an elongated shelf-adjacent seamount in the Bay of Biscay. Deep-Sea Res. I 60, 7-21.

Gracia, FJ., Alonso, C., Benavente, J., Anfuso, G., Del Rio, L, 2006. The different coastal records of the 1755 tsunami waves along the South Atlantic Spanish coast. Z Geomorphol. Suppl. 146, 195-220.

Gross, T.F., Willimans III, A.J., 1991. Characterization of deep-sea storms. Mar. Geol. 99, 281-301.

Guesmia, M., Heinrich, P., Mariotti, C., 1998. Numerical simulation of the 1969 Portuguese tsunami by a finite element method. Nat. Hazards 17 (1), 31-46.

Habgood, E.L., Kenyon, N.H., Masson, D.G., Akhmetzhanov, A., Weaver, P.P.E., Gardner, J. Mulder, T., 2003. Deep-water sediment wave fields, bottom current sand channels and gravity flow channel-lobe systems: Gulf of Cádiz, NE Atlantic. Sedimentology 50, 483-510.

Hanebuth, T.J.J., Zhang, W., Hofmann, A.L., Löwemark, L.A., Schwenk, T., 2015. Oceanic density fronts steering bottom-current induced sedimentation deduced from a 50 ka contourite-drift record and numerical modeling (off NW Spain). Quat. Sci. Rev. 112, 207-225.

Hanebuth, T.J.J., Alekseev, W., Andrade Grand, E.A., Baasch, B., Baumann, K.-H., Behrens, P. Bender, V.B., von Dobeneck, T., dos S Marques, A.I., Frederichs, T., Haberkorn, J., Hangen, J., Hilgenfeldt, C., Just, J., Kockisch, B., Lantzsch, H., Lenhart, A., Lipke, A., Lobo Sánchez, F.J. Mena Rodríguez, A. Müller, H., Petrovic, A., Rodríguez Germade, I, Roud, S. Schwab, A Schwenk, T., Voigt, I., Wenau, S., 2012. Cruise Report and Preliminary Results RV METEOR Cruise M84/4 GALIOMAR III, Vigo-Vigo (Spain), May 1-28, 2011. 283. Fachbereich Geowissenschaften, Universität Bremen, Berichte (139 pp.)

Hanquiez, V., Mulder, T., Toucanne, S., Lecroart, P., Bonnel, C., Marchès, E., Gonthier, E. 2010. The sandy channel-lobe depositional systems in the Gulf of Cádiz: gravity processes forced by contour current processes. Sediment. Geol. 22, 110-123.

van Haren, H., Ribó, M., Puig, P., 2013. (Sub-)inertial wave boundary turbulence in the Gulf of Valencia. J. Geophys. Res. 118, 1-7.

Haynes, R., Barton, E.D., 1990. A poleward flow along the Atlantic coast of the Iberian Peninsula. J. Geophys. Res. 95 (C7), 11425-11441.

Heezen, B.C., Tharp, M., Ewing, M., 1959. The floors of the ocean: 1. The North Atlantic. Geol. Soc. Am. Spec. Pap. 65 (122 pp.)

Henriet, J.P., Hamoumi, N., Da Silva, A.C., Foubert, A., Lauridsen, B.W., Rüggeberg, A., Van Rooij, D., 2014. Carbonate mounds: from paradox to World heritage. Mar. Geol. 352, 89-110.

Hernández-Molina, F.J., Llave, E., Preu, B., Ercilla, G., Fontan, A., Bruno, M., Serra, N., Gomiz, J.J., Brackenridge, R.E., Sierro, F.J., Stow, D.A.V., García, M., Juan, C., Sandoval, N., Arnaiz A., 2014. Contourite processes associated with the Mediterranean outflow water after its exit from the Strait of Gibraltar: global and conceptual implications. Geology 42 227-230.

Hernández-Molina, F.J., Llave, E., Somoza, L., Fernández-Puga, M.C., Maestro, A., León, R Barnolas, A., Medialdea, T., García, M., Vázquez, J.T., Díaz del Río, V., FernándezSalas, L.M., Lobo, F., Alveirinho Dias, J.M., Rodero, J., Gardner, J., 2003. Looking for clues to paleoceanographic imprints: a diagnosis of the Gulf of Cádiz contourite depositional systems. Geology 31, 19-22.

Hernández-Molina, F.J., Maldonado, A., Stow, D.A.V., 2008a. Abyssal plain contourites. In: Rebesco, M., Camerlenghi, A. (Eds.), Contourites. Elsevier, Amsterdam, Developments in Sedimentology 60, pp. 345-378.

Hernández-Molina, F.J., Paterlini, M., Violante, R., Marshall, P., de Isasi, M., Somoza, L., Rebesco, M., 2009. Contourite depositional system on the Argentine slope: an exceptional record of the influence of Antarctic water masses. Geology 37, 507-510.

Hernandez-Molina, F.J., Serra, N., Stow, D.A.V., Llave, E., Ercilla, G., Van Rooij, D., 2011. Along-slope oceanographic processes and sedimentary products around the Iberian margin. Geo-Mar. Lett. 31, 315-341.

Hernández-Molina, F.J., Stow, D.A.V., Alvarez-Zarikian, C., Expedition IODP 339 Scientists, 2013. IODP expedition 339 in the Gulf of Cádiz and off West Iberia: decoding the environmental significance of the Mediterranean outflow water and its global influence. Sci. Drill. 16, 1-11. http://dx.doi.org/10.5194/sd-16-1-2013.

Hernández-Molina, F.J., Stow, D.A.V., Llave, E., 2008b. Continental slope contourites. In: Rebesco, M., Camerlenghi, A. (Eds.), Contourites. Elsevier, Amsterdam, Developments in Sedimentology 60, pp. 379-408.

Hill, A.E., Souza, A.J., Jones, K., Simpson, J.H., Shapiro, G.I., McCandliss, R., Wilson, H., Leftley, J., 1998. The malin cascade in winter 1996. J. Mar. Res. 56, 87-106.

Hindson, R.A., Andrade, C., 1999. Sedimentation and hydrodynamic processes associated with the tsunami generated by the 1755 Lisbon earthquake. Quat. Int. 56, 27-38.
Hindson, R.A., Andrade, C., Dawson, A.G., 1996. Sedimentary processes associated with the tsunami generated by the 1755 Lisbon earthquake on the Algarve coast, Portugal. Phys. Chem. Earth 21, 57-63.

Hoffert, M., 2008. Les Nodules Polymétalliques Dans les Grands Fonds Océaniques. Vuibert, Paris

Hogg, N.G., Stommel, H.M., 1990. How currents in the upper thermocline could advect meddies deeper down. Deep-Sea Res. 37, 613-623.

Holger, K., 1987. Benthic storms, vortices, and particle dispersion in the deep western Europe. Deut. Hydrographische Z. 40, 88-102.

Hollister, C.D., 1967. Sediment Distribution and Deep Circulation in the Western North Atlantic (PhD thesis) Columbia University, New York.

Hollister, C.D., 1993. The concept of deep-sea contourites. Sediment. Geol. 82, 5-11.

Hollister, C.D., Heezen, B.C., 1967. Contour current evidence from abyssal sediments. Trans. Am. Geophys. Union 48 (142 pp.).

Hollister, C.D., Heezen, B.C., 1972. Geological effects of ocean bottom currents: Western North Atlantic. In: Gordon, A.L. (Ed.)Studies in Physical Oceanography 2. Gordon and Breach, N. Y., pp. 37-66.

Hollister, C.D., McCave, I.N., 1984. Sedimentation under deep-sea storms. Nature 309, 220-225.

Hollister, C.D., Nowell, A.R.M., Smith, J.D., 1980. The Third Annual Report of the High Energy Boundary Layer Experiment. WHOI Tech. Rep. 80 pp. 32-48.

Howe, J.A., Stoker, M.S., Stow, D.A.V., 1994. Late Cenozoic sediment drift complex, northeast Rockall Trough, North Atlantic. Paleoceanography 9, 989-999.

Howe, J.A., Stoker, M.S., Stow, D.A.V., Akhurst, M.C., 2002. Sediment drifts and contourite sedimentation in the northeastern Rockall Trough and Faeroe-Shetland Channel, North Atlantic Ocean. In: Stow, D.A.V., Pudsey, C.J. Howe, JA., Faugères, J.-C, Viana, A.R. (Eds.), Deep-Water Contourite Systems: Modern Drifts and Ancient Series, Seismic and Sedimentary Characteristics. Geological Society, London, Memoir 22, pp. 65-72.

Huneke, N.V., Stow, D.A.V., 2008. In: Rebesco, M., Camerlenghi, A. (Eds.), Identification of Ancient Contourites: Problems and Palaeoceanographic SignificanceContourites 60. Elsevier, Developments in Sedimentology, Amsterdam, pp. 323-344.

Huvenne, V.A.I., Van Rooij, D., De Mol, B., Thierens, M., O'Donnell, R., Foubert, A., 2009. Sediment dynamics and palaeo-environmental context at key stages in the challenger cold-water coral mound formation: clues from sediment deposits at the mound base. Deep-Sea Res. I Oceanogr. Res. Pap. 56, 2263-2280.

IGN (Insituto Geográfico Nacional), 1991. El Medio Marino. Atlas Nacional de España, Sección III, Madrid.

Iorga, M., Lozier, M.S., 1999. Signatures of the Mediterranean outflow from a North Atlantic climatology 1 . Salinity and density fields. J. Geophys. Res. 104, 25985-26009

Ivanov, V.V., Shapiro, G.I., Huthnance, J.M., Aleynik, D.L., Golovin, P.N., 2004. Cascades of dense water around the world ocean. Prog. Oceanogr. 60, 47-98.

Jackson, C.R., 2004. An Atlas of Oceanic Internal Solitary Waves. Global Ocean Associates, Rockville, MD (prepared for Office of Naval Research).

Johnson, G.C., Lueck, R.G., Sanford, T.B., 1994a. Stress on the Mediterranean outflow plume: part II. turbulent dissipation and shear measurements. J. Phys. Oceanogr. 24, 2084-2092. http://dx.doi.org/10.1175/1520-0485(1994)024.

Johnson, G.C., Sanford, T.B., Baringer, O'Neil, M., 1994b. Stress on the Mediterranean outflow plume: part i. velocity and water property measurements. J. Phys. Oceanogr. 24, 2072. http://dx.doi.org/10.1175/1520-0485(1994)024.

Johnson, J., Stevens, I., 2000. A fine resolution model of the eastern North Atlantic between the Azores, the Canary Islands, and the Gibraltar Strait. Deep-Sea Res. I 47 (5), 875-899.

Kantha, L.H., Clayson, C.A., 2000a. Small Scale Processes in Geophysical Fluid Flows. Academic 432 Press, San Diego (940 pp.).

Kantha, L.H., Clayson, C.A., 2000b. Numerical Models of Oceans and Oceanic Processes. International Geophysics Series vol. 66. Academic Press (750 pp.)

Käse, R.H., Zenk, W., 1996. Structure of the Mediterranean water and meddy characteristics in the Northeastern Atlantic. In: Krauss, W. (Ed.), The Warmwatersphere of the North Atlantic Ocean. Gebruder Borntraeger, pp. 365-395.

Käse, R.H., Beckmann, A., Hinrichsen, H.-H., 1989. Observational evidence of salt lens formation in the Iberian basin. J. Geophys. Res. 94 (C4), 4905-4912.

Kennett, J.P., 1982. Marine Geology. Prentice-Hall, Englewood.

Killworth, P.D., 1983. Deep convection in the world ocean. Rev. Geophys. Space Phys. 21, $1-26$.

Kuhlbrodt, T., Griesel, A., Montoya, M., Levermann, A., Hofmann, M., Rahmstorf, S., 2007. On the driving processes of the Atlantic meridional overturning circulation. Rev. Geophys. 45, RG2001.

Kunze, K., Rosenfeld, L.K., Carter, G.S., Gregg, M.C., 2002. Internal waves in Monterey submarine canyon. J. Phys. Oceanogr. 32, 1890-1913.

Lastras, G., Arzola, R.G., Masson, D.G., Wynn, R.B., Huvenne, V.A.I., Hühnerbach, V., Canals, M., 2009. Geomorphology and sedimentary features in the Central Portuguese submarine canyons, Western Iberian margin. Geomorphology 103, 310-329.

Laughton, A.S., 1960. An interplain deep-sea channel system. Deep-Sea Res. 7, 75-88.

Laughton, A.S., 1968. New evidence of erosion on the deep ocean floor. Deep-Sea Res. 15, 21-29.

Legg S., Briegleb, B., Chang, Y. Chassignet, E.P., Danabasoglu, G, Ezer, T., Gordon, A.L, Griffies, S., Hallberg, R., Jackson, L., Large, W., Özgökmen, T.M., Peters, H., Price, J., Riemenschneider, U., Wu, W., Xu, X., Yang, J., 2009. Improving oceanic overflow representation in climate models. The gravity current entrainment climate process team. Bull. Am. Meteorol. Soc. 657-670.

Llave, E., Hernández-Molina, F.J., Ercilla, G., García, M., Roque, C., Juan, C., Mena, A., Preu, B., Van Rooij, D., Rebesco, M., Brackenridge, R.E., Jané, G., Stow, D.A.V., GómezBallesteros, M., 2015b. Deep wáter circulation around the Iberian continental margin: state of the art and future implications. Mar. Geol. (Present Special Issue). 
Llave, E., Hernández-Molina, F.J., Ercilla, G., Roque, C., Van Rooij, D., García, M., Juan, C. Mena, A., Brackenridge, R., Jané, G., Stow, D., Gómez-Ballesteros, M., 2015a. Bottom current processes along the Iberian continental margin. Bol. Geol. Min. 126 (2-3), 219-256.

Llave, E., Hernández-Molina, F.J., Somoza, L., Stow, D.A.V., Díaz del Río, V., 2007. Quaternary evolution of the contourite depositional system in the Gulf of Cádiz. In: Viana, A.R., Rebesco, M. (Eds.), Economic and Palaeoceanographic Significance of Contourite Deposits. Geological Society, London, Special Publication 276, pp. 49-79.

Lobo, F.J., Hernández-Molina, F.J., Bohoyo, F., Galindo-Zaldívar, J., Maldonado, A., Martos, Y.M., Rodríguez-Fernández, J., Somoza, L., Vázquez, J.T., 2011. Furrows in the southeastern scan basin, Antarctica: interplay between tectonic and oceanographic influences. Geo-Mar. Lett. 31 (5-6), 451-464.

Luque, L., 2002. Cambios en los Paleoambientes Costeros del sur de la Península Ibérica (España) Durante el Holoceno (Tesis Doctoral) Universidad Complutense de Madrid.

Luque, L., Lario, J., Zazo, C., Goy, J.L., Dabrio, C.J., Silva, P.G., 2001. Tsunami deposits as palaeoseismic indicators: examples from the Spanish coast. Acta Geol. Hisp. 36 (34), 197-211.

Luque, L., Zazo, C., Goy, J.L., Dabrio, C.J., Civis, J., Lario, J., Gómez-Ponce, C., 1999. Los depósitos del tsunami de Lisboa de 1755. Su Registro en la Bahía de Cádiz: Flecha de Valdelagrana (Spain)En Actas de la X Reunión Nacional del 152 Luis de Luque, RAMPAS, 10, 2008 Revista Atlántica-Mediterránea de Prehistoria y Arqueología Social 10. Universidad de Cádiz Cuaternario, Girona, pp. 131-153 (63-66)

Luque, L., Zazo, C., Lario, J., Goy, J.L., Civis, J., González-Hernández, F.M., Silva, P G., Dabrio, C.J. 2004. El efecto del tsunami del año 1755 en el litoral de Conil de la Frontera (Cádiz). In: Baquedano, E., Rubio, S., (Coords.): Miscelanea en homenaje a Emiliano Aguirre 1. Geología, pp. 72-82. Madrid.

Maestro, A., Ercilla, G., Hernández-Molina, F.J., 2015. Geological processes in the Iberian continental margin: new developments and trends. Bol. Geol. Min. 126 (2-3) (633 pp.).

Maestro, A., López-Martínez, J., Llave, E., Bohoyo, F., Acosta, J., Hernández-Molina, F.J., Muñoz, A., Jané, G., 2013. Geomorphology of the Iberian continental margin. Geomorphology 196, 13-35.

Marta-Almeida, M., Dubert, J., 2006. The structure of tides in the western Iberian region. Cont. Shelf Res. 26, 385-400.

Martín, J., Durrieu de Madron, X., Puig, P., Bourrin, F., Palanques, A., Houpert, L., Higueras, M., Sanchez-Vidal, A., Calafat, A.M., Canals, M., Heussner, S., 2013. Sediment transport along the Cap de Creus Canyon flank during a mild, wet winter. Biogeosciences 10, 3221-3239.

Martín-Chivelet, J., Fregenal Martínez, M.A., Chacón, B., 2008. Traction structures in contourites. In: Rebesco, M., Camerlenghi, A. (Eds.), Contourites. Elsevier, Amsterdam, Developments in Sedimentology 60, pp. 159-181.

Masson, D.G., Plets, R.M.K., Huvenne, V.A.I., Wynn, R.B., Bett, B.J., 2010. Sedimentology and depositional history of Holocene sandy contourites on the lower slope of the FaroeShetland Channel, northwest of the UK. Mar. Geol. 268, 85-96.

McCartney, M.S., 1992. Recirculating components to the deep boundary current of the northern North Atlantic. Prog. Oceanogr. 29, 283-383.

McCave, I.N., 1986. Local and global aspects of the bottom nepheloid layers in the world ocean. Neth. J. Sea Res. 20, 167-181.

McCave, I.N., Carter, L., 1997. Recent sedimentation beneath the deep western boundary current off northen New Zealand. Deep-Sea Res. I Oceanogr. Res. Pap. 44, 1203-1237.

McCave, I.N., Tucholke, B.E., 1986. Deep current-controlled sedimentation in the western North Atlantic. In: Vogt, P.R., Tucholke, B.E. (Eds.), The Geology of North America, The Western North Atlantic Region, Decade of North American Geology. Boulder, Geological Society of America, pp. 451-468.

Millot, C., 1999. Circulation in the Western Mediterranean Sea. J. Mar. Syst. 20, 423-442.

Millot, C., 2009. Another description of the Mediterranean Sea outflow. Prog. Oceanogr. 101-124. http://dx.doi.org/10.1016/j.pocean.2009.04.016.

Millot, C., 2014. Heterogeneities of in- and out-flows in the Mediterranean sea. Prog. Oceanogr. 120, 254-278.

Millot, C., Candela, J., Fuda, J.L., Tber, Y., 2006. Large warming and salinification of the Mediterranean outflow due to changes in its composition. Deep-Sea Res. I 53, 423-442.

Millot, C.A., 1990. The Gulf of Lions' hydrodynamic. Cont. Shelf Res. 10, 885-894.

Muench, R.D., Wåhlin, A.K., Özgökmen, T.M., Hallberg, R., Padman, L., 2009. Impacts of bottom corrugations on a dense Antarctic outflow: NW Ross Sea. Geophys. Res. Lett. 36, L23607.

Mulder, T., Hassan, R., Ducassou, E., Zaragosi, S., Gonthier, E., Hanquiez, V., Marchès, E., Toucanne, S., 2013. Contourites in the Gulf of Cádiz: a cautionary note on potentially ambiguous indicators of bottom current velocity. Geo-Mar. Lett. 33, 357-367.

Navrotsky, V.V., Lozovatsky, J.D., Pavlova, E.P., Fernando, H.J.S., 2004. Observations of internal waves and thermocline splitting near a shelf break of the Sea of Japan (East Sea). Cont. Shelf Res. 24, 1375-1395.

Nelson, C.H., Baraza, J., Maldonado, A., 1993. Mediterranean undercurrent sandy contourites, gulf of Cádiz, Spain. Sediment. Geol. 82 (1-4), 103-131.

Nof, D., 1982. On the beta-induced movement of isolated baroclinic eddies. J. Phys. Oceanogr. 11, 1662-1672.

Nof, D., 1991. Lenses generated by intermittent currents. Deep-Sea Res. 38 (3), 325-345.

Nowell, A.R.M., Hollister, C.D., 1985. Deep ocean sediment transport - preliminary results of the high energy benthic boundary layer experiment. Mar. Geol. 66 (420 pp.).

Ochoa, J., Bray, N.A., 1991. Water mass exchange in the Gulf of Cádiz. Deep Sea Res. Part A 38 (S1), S465-S503.

Orsi, A.H., Whitworth, T.I.I.I., Nowlin Jr., W.D., 1995. On the meridional extent and fronts of the Antarctic circumpolar current. Deep-Sea Res. I 42, 641-673.

Øvrebø, L.K., Haughton, P.D.W., Shannon, P.M., 2006. A record of fluctuating bottom currents on the slopes west of the porcupine bank, offshore Ireland - implications for late quaternary climate forcing. Mar. Geol. 225, 279-309.
Paillet, J., Mercier, H., 1997. An inverse model of the eastern North Atlantic general circulation andthermocline ventilation. Deep-Sea Res. I 44 (8), 1293-1328.

Paillet, J., Le Cann, B., Carton, X., Morel, Y., Serpette, A., 2002. Dynamics and evolution of a northern meddy. J. Phys. Oceanogr. 32, 55-79.

Palanques, A., Durrieu de Madron, X., Puig, P., Fabrés, J., Guillén, J., Calafat, A., Canals, M. Heussner, S., Bonnin, J., 2006. Suspended sediment fluxes and transport processes in the Gulf of Lions submarine canyons. The role of storms and dense water cascading. Mar. Geol. 234, 43-61.

Palanques, A., Guillén, J., Puig, P., Durrieu de Madron, X., 2008. Storm-driven shelf-tocanyon suspended sediment transport at the southwestern end of the Gulf of Lions. Cont. Shelf Res. 28, 1947-1956.

Palanques, A., Puig, P., Durrieu de Madron, X., Sanchez-Vidal, A., Pasqual, C., Martín, J., Calafat, A., Heussner, S., Canals, M., 2012. Sediment transport to the deep canyons and open-slope of the western Gulf of Lions during the 2006 intense cascading and open-sea convection period. Prog. Oceanogr. 106, 1-15.

Palanques, A., Puig, P., Latasa, M., Scharek, R., 2009. Deep sediment transport induced by storms and dense shelf water cascading in the northwestern Mediterranean basin Deep-Sea Res. I 56, 425-434.

Palomino, D., Vazquez, J.T., Ercilla, G., Alonso, B., Lopez-Gonzalez, N., Diaz-del-Rio, V., 2011. Interaction between seabed morphology and water masses around the seamounts on the motril marginal plateau (Alboran Sea, Western Mediterranean) Geo-Mar. Lett. 31, 465-479.

Pedlosky, J., 1996. Ocean Circulation Theory. Springer-Verlag, Heidelberg (453 pp.).

Pichevin, T., Nof, D., 1996. The Eddy Cannon. Deep-Sea Res. 43 (9), 1475-1507.

Pichon, A., Morel, Y., Baraille, R., Quaresma, L.S., 2013. Internal tide interactions in the Bay of Biscay: observations and modeling. J. Mar. Syst. 109-110, S26-S44.

Pickering, K.T., Hiscott, R.N., Hein, F.J., 1989. Deep Marine Environments: Clastic Sedimentation and Tectonics. Unwin Hyman, London (416 pp.).

Pingree, R.D., Le Cann, B., 1993. Structure of a Meddy (Bobby 92) Southeast of the Azores. Deep-Sea Res. 40, 2077-2103.

Pingree, R.D., New, A.L., 1989. Downward propagation of internal tidal energy into the Bay of Biscay. Deep-Sea Res. 36 (5), 735-758.

Pingree, R.D., New, A.L., 1991. Abyssal penetration and bottom reflection of internal tidal energy in the Bay of Biscay. J. Phys. Oceanogr. 21, 28-39.

Pingree, R.D., Mardell, G.T., New, A.L., 1986. Propagation of internal tides from the upper slopes of the bay of Biscay. Nature 321, 154-158.

Pinheiro, L.M., Song, H., Ruddick, B., Dubert, J., Ambar, I., Mustafa, K., Bezerra, R., 2010. Detailed 2-D imaging of the Mediterranean outflow and meddies off W Iberia from multichannel seismic data. J. Mar. Syst. 79, 89-100.

Piola, A.R., Matano, R.P., 2001. Brazil and Falklands (Malvinas) Currents. Academic Press, London.

Piper, D.J.W., 1972. Sediments of the middle Cambrian Burgess Shale, Canada. Lethaia 5 169-175.

Prater, M.D., Sanford, T.B., 1994. A meddy off cape St. Vincent. Part I: description. J. Phys. Oceanogr. 24, 1572-1586.

Preu, B., Hernández-Molina, F.J., Violante, R., Piola, A.R., Paterlini, C.M., Schwenk, T., Voigt, I., Krastel, S., Spiess, V., 2013. Morphosedimentary and hydrographic features of the northern Argentine margin: the interplay between erosive, depositional and gravitational processes and its conceptual implications. Deep-Sea Res. I Oceanogr. Res. Pap. $75,157-174$.

Preu, B., Spieß, V., Schwenk, T., Schneider, R., 2011. Evidence for current-controlled sedimentation along the southern Mozambique continental margin since early Miocene times. Geo-Mar. Lett. 31, 427-435.

Price, J.F., Baringer, M.O., 1994. Outflows and deep water production by marginal seas. Prog. Oceanogr. 33, 161-200.

Puig, P., Durrieu de Madron, X., Salat, J., Schroeder, K., Martín, J., Karageorgis, A.P., Palanques, A., Roullier, F., Lopez-Jurado, J.L., Emelianov, M., Moutin, T., Houpert, L., 2013. Thick bottom nepheloid layers in the western Mediterranean generated by deep dense shelf water cascading. Prog. Oceanogr. 111, 1-23.

Puig, P., Palanques, A., Guillén, J., 2001. Near-bottom suspended sediment variability caused by storms and near-inertial internal waves in the Ebro mid continental shelf (NW Mediterranean). Mar. Geol. 178, 81-93.

Puig, P., Palanques, A., Guillén, J., El Khatab, M., 2004. Role of internal waves in the generation of nepheloid layers on the northwestern Alboran slope: implications for continental margin shaping. J. Geophys. Res. 109, C09011.

Puig, P., Palanques, A., Martín, J., 2014. Contemporary sediment-transport processes in submarine canyons. Ann. Rev. Mar. Sci. 6, 53-77.

Puig, P., Palanques, A., Martín, J., Ribó, M., Font, J., 2012. Eventos de resuspensión de sedimento en el ascenso continental del margen Mediterráneo noroccidental. Geotemas 1840-1843.

Puig, P., Palanques, A., Orange, D.L., Lastras, G., Canals, M., 2008. Dense shelf water cascading and furrows formation in the Cap de Creus Canyon, northwestern Mediterranean sea. Cont. Shelf Res. 28, 2017-2030.

Quaresma, L.S., Pichon, A., 2013. Modelling the barotropic tide along the west-Iberian margin. J. Mar. Syst. 109-110, S3-S25.

Quaresma, L.S., Vitorino, J., Oliveira, A., DaSilva, J., 2007. Evidence of sediment resuspension by nonlinear internal waves on the western Portuguese mid-shelf. Mar. Geol 246, 123-143.

Rahmstorf, S., 2006. Thermohaline ocean circulation. In: Elias, S.A. (Ed.), Encyclopedia of Quaternary Science. Elsevier, Amsterdam, pp. 739-750.

Rebesco, M., Camerlenghi, A. (Eds.), 2008. Contourites. Elsevier, Amsterdam, Developments in Sedimentology 60.

Rebesco, M., 2005. Contourites. In: Richard, C., Selley, R.C., Cocks, L.R.M., Plimer, I.R. (Eds.), Encyclopedia of geology 4. Elsevier, London, pp. 513-527.

Rebesco, M., Stow, D.A.V., 2001. Seismic expression of contourites and related deposits: preface. Mar. Geophys. Res. 22, 303-308. 
Rebesco, M., Hernández-Molina, F.J., Van Rooij, D., Wåhlin, A., 2014. Contourites and associated sediments controlled by deep-water circulation processes: state of the art and future considerations. Mar. Geol. 352, 111-154. http://dx.doi.org/10.1016/j.margeo. 2014.03.011.

Rebesco, M., Wåhlin, A., Laberg, J.S., Schauer, A., Brezcynska-Möller, A., Lucchi, R.G Noormets, R., Accettella, D., Zarayskaya, Y., Diviacco, P., 2013. Quaternary contourite drifts of the Western Spitsbergen margin. Deep-Sea Res. I Oceanogr. Res. Pap. 79, $156-168$.

Reicherter, K., 2001. Paleoseismologic advances in the Granada basin (Betic Cordilleras, Southern Spain). Acta Geol. Hisp. 36 (3-4), 267-281.

Reicherter, K., Becker-Heidmann, P., 2009. Tsunami deposits in the western Mediterranean: remains of the 1522 almería earthquake? Soc. Lond. Mem. 316 217-235.

Reid, J.L., Nowlin, W.D., Patzert, W.C., 1977. On the characteristics and circulation of the Southwestern Atlantic Ocean. J. Phys. Oceanogr. 7, 62-91.

Ribó, M., Puig, P., van Haren, H., 2015a. Hydrodynamics over the Gulf of Valencia continental slope and their role in sediment transport. Deep-Sea Res. I 95, 54-66.

Ribó, M., Puig, P., Urgeles, R., Van Rooij, D., Muñoz, A., 2016c. Spatio-temporal evolution of the sediment waves developed on the Gulf of Valencia margin (NW Mediterranean) during the Plio-Quaternary. Mar. Geol. 378, 276-291.

Ribó, M., Puig, P., Muñoz, A., Lo lacono, C., Masqué, P., Palanques, A., Acosta, J., Guillén, J. Gómez Ballesteros, M., 2015b. Morphobathymetric analysis of the large fine-grained sediment waves over the Gulf of Valencia continental slope (NW Mediterranean). Geomorphology 253C, 22-37. http://dx.doi.org/10.1016/j.geomorph.2015.09.027.

Ribó, M., Puig, P., Palanques, A., Lo Iacono, C., 2011. Dense shelf water cascades in the Cap de Creus and Palamós submarine canyons during winters 2007 and 2008. Mar. Geol. 284, 175-188.

Richardson, M.J., Weatherly, G.L., Gardner, W.D., 1993. Benthic storms in the argentine basin. Deep-Sea Res. II 40, 989-999.

Richardson, P.L., Bower, A.S., Zenk, W., 2000. A census of meddies tracked by floats. Prog. Oceanogr. 45, 209-250.

Richardson, P.L., Walsh, D., Armi, L., Schroder, M., Price, J.F., 1989. Tracking three meddies with SOFAR floats. J. Phys. Oceanogr. 19, 371-383.

Roberts, D.G., Hogg, N.G., Derek, G., Bishop, G., Flewellen, C.G., 1974. Sediment distribution around moated seamounts in the Rockall Trough. Deep-Sea Res. Part A 21, 175-184

Roden, G.I., 1987. Effects of seamount chains on ocean circulation and thermohaline structure. In: Keating, B.H., et al. (Eds.), Seamounts, Islands and Atolls. AGU Geophysics Monograph 96, pp. 335-354.

Rodríguez-Vidal, J., Ruiz, F., Cáceres, L.M., Abad, M., González-Regalado, M.L., Pozo, M., Carretero, M.I., Monge, A.M., Gómez, F., 2011. Geomarkers of the 218-209 BC Atlantic tsunami in the Roman Lacus Ligustinus (SW Spain): a palaeogeographical approach. Quat. Int. 242, 201-212.

Roger, J., Hébert, H., 2008. The 1856 Djijelli (Algeria) earthquake and tsunami: source parameters and implications for tsunami hazard in the Balearic Islands. Nat. Hazards Earth Syst. Sci. 8, 721-731.

Rogers, A.D., 1994. The biology of seamounts. Adv. Mar. Biol. 30, 305-340.

Rogerson, M., Rohling, E.J., Bigg, G.R., Ramirez, J., 2012. Paleoceanography of the AtlanticMediterranean exchange: overview and first quantitative assessment of climatic forcing. Rev. Geophys. 50, RG2003.

Rona, P.A., 2008. The changing vision of marine minerals. Ore Geol. Rev. 33, 618-666.

Roveri, M., Flecker, R., Krijgsman, W., Lofi, J., Lugli, S., Manzi, V., Sierro, F.J., Bertini, S., Camerlenghi, A., De Lange, G., Govers, R., Hilgen, F.J., Hübscher, C., Meijer, P.T., Stoica, M., 2014. The Messinian salinity crisis: past and future of a great challenge for marine sciences. Mar. Geol. 352, 25-58. http://dx.doi.org/10.1016/j.margeo. 2014.02.002.

Ruiz, F., Rodrıguez-Ramırez, A., Caceres, L.M., Rodriguez Vidal, J.R., Carretero, M.I., Abad, M., Olias, M., Pozo, M., 2005. Evidence of high-energy events in the geological record: mid-Holocene evolution of the southwestern Doñana National Park (SW Spain) Palaeogeogr. Palaeoclimatol. Palaeoecol. 229, 212-229.

Ruiz, F., Rodrıguez-Ramirez, A., Caceres, L.M., Rodriguez Vidal, J.R., Carretero, M.I. Clemente, L., Muñoz, J.M., Yañez, C., Abad, M., 2004. Late Holocene evolution of the southwestern Doñana National Park (Guadalquivir Estuary, SW Spain): a multivariate approach. Palaeogeogr. Palaeoclimatol. Palaeoecol. 204, 47-65.

Rumín-Caparrós, A., Sanchez-Vidal, A., Calafat, A., Canals, M., Martín, J., Puig, P., PedrosaPàmies, R., 2013. External forcings, oceanographic processes and particle flux dynamics in Cap de Creus submarine canyon, NW Mediterranean Sea. Biogeosciences 10 3493-3505.

Sadoux, S., Baey, J.-M., Fincham, A., Renouard, D., 2000. Experimental study of the stability of an intermediate current and its interaction with a cape. Dyn. Atmos. Oceans 31, 165-192.

Sahal, A., Roger, J., Allgeyer, S., Lemaire, B., Hebert, H., Schindelé, F., Lavigne, F., 2009. The tsunami triggered by the 21 May 2003 Boumerdes-Zmmouri (Algeria) earthquake: field investigations on the French Mediterranean coast and tsunami modelling. Nat. Hazards Earth Syst. Sci. 9, 1823-1834.

Salat, J., Puig, P., Latasa, M., 2010. Violent storms within the sea: dense water formation episodes in the NW Mediterranean. Adv. Geosci. 26, 53-59.

Sánchez, F., González-Pola, C., Druet, M., García-Alegre, A., Acosta, J., Cristobo, J., Parra, S. Ríos, P., Altuna, A., Gómez-Ballesteros, M., Muñoz-Recio, A., Rivera, J., Díaz del Río, G. 2014. Habitat characterization of deep-water coral reefs in LaGaviera canyon (Avilés Canyon System, Cantabrian Sea). Deep-Sea Res. II 106, 118-140.

Sánchez González, J.M., 2013. Oceanographic and Morphosedimentary Features in the Northwestern Sector of the Galicia Margin: Implications (MSc work) University of Vigo, Spain

Sánchez-Garrido, J.C., Sannino, G., Liberti, L., García Lafuente, J., Pratt, L., 2011. Numerical modelingof three-dimensional stratified tidal flow over Camarinal Sill, Strait of Gibraltar. J. Geophys. Res. 116, C12026. http://dx.doi.org/10.1029/2011JC007093.
Sánchez-Román, A., Sannino, G., García-Lafuente, J., Carillo, A., Criado-Aldeanueva, F., 2009. Transport estimates at the western section of the Strait of Gibraltar: a combined experimental and numerical modeling study. J. Geophys. Res. 114, C06002. http://dx.doi.org/10.1029/2008JC005023.

Santek, D.A., Winguth, A., 2005. A satellite view of internal waves induced by the Indian Ocean tsunami. Int. J. Remote Sens. 26, 2927-2936.

Scheffers, A., Kelletat, D., 2005. Tsunami relics in the coastal landscape west of Lisbon, Portugal. Sci. Tsunami Haz. 23, 3-16.

Schönfeld, J., Zahn, R., Abreu, L., 2003. Surface and deep water response to rapid climate changes at the Western Iberian Margin. Glob. Planet. Chang. 36, 237-264.

Schultz-Tokos, K., Rossby, T., 1991. Kinematics and dynamics of a Mediterranean salt lens. J. Phys. Oceanogr. 21, 879-892.

Schultz-Tokos, K., Hinrichsen, H.-H., Zenk, W., 1994. Merging and migration of two meddies. J. Phys. Oceanogr. 24 (10), 2129-2141.

Serra, N., 2004. Observations and Numerical Modelling of the Mediterranean Outflow (PhD Thesis) University of Lisbon.

Serra, N., Ambar, I., 2002. Eddy generation in the Mediterranean undercurrent. Deep-Sea Res. II 49 (19), 4225-4243.

Serra, N., Ambar, I., Boutov, D., 2010a. Surface expression of Mediterranean water dipoles and their contribution to the shelf/slope - open ocean exchange. Ocean Sci. 6, 191-209.

Serra, N., Ambar, I., Käse, R.H., 2005. Observations and numerical modelling of the Mediterranean outflow splitting and eddy generation. Deep-Sea Res. II 52, 383-408

Serra, N., Köhl, R.K.A., Stammer, D., 2010b. On the low-frequency phase relation between the Danmark Strait and the Faroe-Bank Channel overflows. Tellus Ser. A Dyn. Meteorol. Oceanogr. 62, 530-550.

Serra, N., Sadoux, S., Ambar, I., Renouard, D., 2002. Observations and laboratory modelling of meddy generation at Cape St. Vincent. J. Phys. Oceanogr. 32, 3-25.

Shanmugam, G., 2012a. New perspectives on deep-water sandstones: origin, recognition, initiation, and reservoir quality. Handbook of Petroleum Exploration and Production 9. Elsevier, Amsterdam (524 pp.)

Shanmugam, G., 2000. 50 years of the turbidite paradigm (1950s-1990s): deep-water processes and facies models-a critical perspective. Mar. Pet. Geol. 17, 285-342.

Shanmugam, G., 2006. The tsunamite problem. J. Sediment. Res. 76, 718-730.

Shanmugam, G., 2012b. Process-sedimentological challenges in distinguishing paleotsunami deposits. In: Kumar, A., Nister, I. (Eds.), Paleo-tsunamis: Natural Hazards 63, pp. 5-30

Shanmugam, G., 2013a. Modern internal waves and internal tides along oceanic pycnoclines: challenges and implications for ancient deep-marine baroclinic sands. AAPG Bull. 97, 767-811.

Shanmugam, G., 2013b. New perspectives on deep-water sandstones: implications. Pet. Explor. Dev. 40, 316-324.

Shanmugam, G., 2014. Modern internal waves and internal tides along oceanic pycnoclines: challenges and implications for ancient deep-marine baroclinic sands: reply. AAPG Bull. 98 (4), 858-879.

Shanmugam, G., Spalding, T.D., Rofheart, D.H., 1993. Process sedimentology and reservoir quality of deep-marine bottom-current reworked sands (sandy contourites): an example from the Gulf of Mexico. AAPG Bull. 77, 1241-1259.

Shapiro, G.I., Hill, A.E., 1997. Dynamics of dense water cascades at the shelf edge. J. Phys. Oceanogr. 27, 2381-2394

Shapiro, G.I., Huthnance, J.M., Ivanov, V.V., 2003. Dense water cascading off the continental shelf. J. Geophys. Res. 108 (C12), 3390. http://dx.doi.org/10.1029/2002JC001610.

Shepard, F.P., 1976. Tidal components of currents in submarine canyons. J. Geol. 84 , 343-350.

Shepard, F.P., Marshall, N.F., McLoughlin, P.A., Sullivan, G.G., 1979. Currents in submarine canyons and other sea valleys. AAPG Tulsa Stud. Geol. 8.

Simpson, J.E., 1982. Gravity currents in the laboratory, atmosphere and ocean. Annu. Rev. Fluid Mech. 14, 213-234.

Somoza, L., Ercilla, G., Urgorri, V., León, R., Medialdea, T., Paredes, M., Gonzalez, F.J., Nombela, M.A., 2014. Detection and mapping of cold-water coral mounds and living Lophelia reefs in the Galicia Bank, Atlantic NW Iberia margin. Mar. Geol. 349, 73-90.

Stabholz M Durrieu de Madron, X Canals, M., Khripounoff, A Taupier-Letage, I, Testor, P., Heussner, S., Kerherv'e, P., Delsaut, N., Houpert, L., Lastras, G., Dennielou, B., 2013. Impact of open-ocean convection on particle fluxes and sediment dynamics in the deep margin of the Gulf of Lions. Biogeosciences 10, 1097-1116.

Stoker, M.S., Akhurst, M.C., Howe, J.A., Stow, D.A.V., 1998. Sediment drifts and contourites on the continental margin off northwest Britain. Sediment. Geol. 115, 33-51.

Stow, D.A.V., 2005. Sedimentary Rocks in the Field: A Colour Guide. Manson Publishing, London.

Stow, D.A.V., Faugères, J.C., 2008. Contourite facies and the facies model. In: Rebesco, M., Camerlenghi, A. (Eds.), Contourites. Elsevier, Amsterdam, Developments in Sedimentology 60, pp. 223-256.

Stow, D.A.V., Holbrook, JA, 1984. North Atlantic contourites: an overview. In: Stow, D.A.V., Piper, D.J.W. (Eds.), Fine Grained Sediments, Deep-Water Processes and Facies. Geological Society, London, Special Publication 15, pp. 245-256.

Stow, D.A.V., Hernández-Molina, F.J., Alvarez Zarikian, C.A., the Expedition 339 Scientists, 2013b. Proceedings IODP, 339. Integrated Ocean Drilling Program Management International, Tokyo http://dx.doi.org/10.2204/iodp.proc.339.2013.

Stow, D.A.V., Hernández-Molina, F.J., Llave, E., Bruno, M., García, M., Díaz del Río, V. Somoza, L., Brackenridge, R.E., 2013a. The Cádiz contourite channel: sandy contourites, bedforms and dynamic current interaction. Mar. Geol. 343, 99-114.

Stow, D.A.V., Faugères, J.-C., Howe, J.A., Pudsey, C.J., Viana, A.R., 2002b. Bottom currents, contourites and deep-sea sediment drifts: current state-of-the-art. In: Stow, D.A.V. Pudsey, C.J., Howe, J.A., Faugères, J.-C., Viana, A.R. (Eds.), Deep-Water Contourite 
Systems: Modern Drifts and Ancient Series, Seismic and Sedimentary Characteristics. Geological Society, London, Memoirs 22, pp. 7-20.

Stow, D.A.V., Hernández-Molina, F.J., Llave, E., Sayago-Gil, M., Díaz-del Río, V., Branson, A., 2009. Bedform-velocity matrix: the estimation of bottom current velocity from bedform observations. Geology 37, 327-330.

Stow, D.A.V., Pudsey, C.J., Howe, J.A., Faugères, J.-C., Viana, A.R., 2002a. Deep-water contourite systems: modern drifts and ancient series, seismic and sedimentary characteristics. Geol. Soc. Lond. Mem. 22

Sweeney, E.M., Gardner, J.V., Johnson, J.E., Mayer, L.A., 2012. Geological interpretations of a low-backscatter anomaly found on the New Jersey continental margin. Mar. Geol. 326-328, 46-54.

Toucanne, S., Mulder, T., Schönfeld, J., Hanquiez, V., Gonthier, E., Duprat, J., Cremer, M., Zaragosi, S., 2007. Contourites of the Gulf of Cadiz: a high-resolution record of the paleocirculation of the Mediterranean outflow water during the last 50,000 years. Palaeogeogr. Palaeoclimatol. Palaeoecol. 246, 354-366.

Trincardi, F., Foglini, F., Verdicchio, G., Asioli, A., Correggiari, A., Minisini, D., Piva, A., Remia, A., Ridente, D., Taviani, M., 2007. The impact of cascading currents on the Bari Canyon System, SW-Adriatic margin (Central Mediterranean). Mar. Geol. 246 (2-4), 208-230.

Tucholke, B.E., 2002. The Greater Antilles Outer Ridge: development of a distal sedimentary drift by deposition of fine-grained contourites. In: Stow, D.A.V., Pudsey, C.J., Howe, J.A., Faugères, J.-C., Viana, A.R. (Eds.), Deep-Water Contourite Systems: Modern Drifts and Ancient Series, Seismic and Sedimentary Characteristics. Geological Society, London, Memoirs 22, pp. 39-55.

Van Rooij, D., Blamart, D., De Mol, L., Mienis, F., Pirlet, H., Wehrmann, L.M., Barbieri, R., Maignien, L., Templer, S.P., de Haas, H., Hebbeln, D., Frank, N., Larmagnat, S., Stadnitskaia, A., Stivaletta, N., van Weering, T., Zhang, Y., Hamoumi, N., Cnudde, V., Duyck, P., Henriet, J.P., 2011. Cold-water coral mounds on the Pen Duick Escarpment, Gulf of Cádiz: the MiCROSYSTEMS project approach. Mar. Geol. 282, 102-117.

Van Rooij, D., Iglesia, J., Hernández-Molina, F.J., Ercilla, G., Gomez-Ballesteros, M., Casas, D., Llave, E., De Hauwere, A., Garcia-Gil, S., Acosta, J., Henriet, J.-P., 2010. The Le Danois Contourite Depositional System: Interactions between the Mediterranean Outflow Water and the upper Cantabrian slope (North Iberian margin). Mar. Geol. 274, 1-20.

Viana, A.R., 2008. Economic relevance of contourites. In: Rebesco, M., Camerlenghi, A. (Eds.), Contourites. Elsevier, Amsterdam, Developments in Sedimentology 60, pp. 493-510.

Viana, A.R., Faugères, J.-C., 1998. Upper slope sand deposits: the example of Campos Basin a latest Pleistocene/Holocene record of the interaction between along and across slope currents. In: Stoker, M.S., Evans, D., Cramp, A. (Eds.), Geological Processes on
Continental Margins - Sedimentation, Mass-Wasting and Stability. Geological Society, London, Special Publication 129, pp. 287-316.

Viana, A.R., Faugères, J.-C., Stow, D.A.V., 1998. Bottom-current controlled sand deposits: a review from modern shallow to deep water environments. Sediment. Geol. 115, 53-80.

Viana- Baptista, M.A., Soares, P.M., Miranda, J.M., Luis, J.F., 2006. Tsunami propagation along Tagus estuary (Lisbon, Portugal) preliminary results. Sci. Tsunami Haz. 24 (5), 329-338.

Vlasenko, V., Sánchez Garrido, J.C., Stashchuk, N., García Lafuente, J., Losada, M., 2009. Three-dimensional evolution of large-amplitude internal waves in the Strait of Gibraltar. J. Phys. Oceanogr. 39, 2230-2246.

Voelker, A.H.L., Lebreiro, S.M., Schönfeld, J., Cacho, I., Erlenkeuser, H., Abrantes, F., 2006 Mediterranean outflow strengthening during northern hemisphere coolings: a salt source for the glacial Atlantic? Earth Planet. Sci. Lett. 245 (1-2), 39-55.

Von Lom-Keil, H., Speiss, V. Hopfauf, V , 2002. Fine-grained sediment waves on the western flank of the zapiola drift, argentine basin - evidence for variations in late quaternary bottom flow activity. Mar. Geol. 192, 239-258.

Wåhlin, A., 2004. Topographic advection of dense bottom water. J. Fluid Mech. 210, 95-104.

Wåhlin, A.K., Walin, G., 2001. Downward migration of dense bottom currents. Environ. Fluid Mech. 1, 257-279.

Whelan, F., Kelletat, D., 2005. Boulder deposits on the southern Spanish Atlantic coast: possible evidence for the 1755 AD Lisbon tsunami? Sci. Tsunami Hazards 23 (3), 25-38.

Wright, S.G., Rathje, E.M., 2003. Triggering mechanisms of slope instability and their relationship to earthquakes and tsunamis. Pure Appl. Geophys. 160 (10-11), 1865-1877.

Wunsch, C., 2002. What is the thermohaline circulation? Science 298 (5596), 1179-1181. http://dx.doi.org/10.1126/science.1079329, PMID 12424356.

Zenk, W., 2008. Abyssal and Contour Currents. In: Rebesco, M., Camerlenghi, A. (Eds.), Contourites. Elsevier, Amsterdam, Developments in Sedimentology 60, pp. 37-57.

Zenk, W., Armi, L., 1990. The complex spreading pattern of Mediterranean water off the Portuguese continental slope. Deep-Sea Res. 37, 1805-1823.

Zitellini, N., Gràcia, E., Matias, L., Terrinha, P., Abreu, M.A., DeAlteriis, G., Henriet, J.P., Dañobeitia, J.J., Masson, D.G., Mulder, T., Ramella, R., Somoza, L., Diez, S., 2009. The quest for the Africa-Eurasia plate boundary west of the Strait of Gibraltar. Earth Planet. Sci. Lett. 280 (1-4), 13-50. 